\title{
THE PAPERS OF THE \\ BIBLIOGRAPHICAL SOCIETY \\ OF AMERICA
}

Volume One Hundred Eight

MARCH 2014

\section{CONTENTS}

The Place of Musical Settings in Author Bibliographies, with Examples from Christina Rosetti

By Maura Ives

Caxton's Editing of the Canterbury Tales

By Barbara Bordalejo

Henry Delahay Symonds and James Ridgway's Conversion

from Whig Pamphleteers to Doyens of the Radical Press, 1788-1793

By Peter Robinson

$6 I$

BIBLIOGRAPHICAL NOTES

Caxton's Death-Bed Prayers in Manuscript and Print By A. S. G. Edwards

Stemmata for Shakepeare Texts: A Suggested New Form By Pervez Rizvi

Finding Matthew Parker in Manuscripts of the Anglo-Saxon Chronicle

By Nicholas Sparks

BOOK REVIEWS

Bland, Mark. A Guide to Early Printed Books and Manuscripts.

(Kevin J. Donovan) 
Mak, Bonnie. How the Page Matters.

(Brett A. Hudson)

Warner, J. Christopher, ed. John Bale's Catalogue of Tudor Authors: An Annotated Translation of Records from the "Scriptorum illustrium maioris Brytanniae... Catalogus" (1557-1559).

(Brett A. Hudson)

ANNUAL INDEX 


\section{Editor of the Papers: David L. Gants \\ Managing Editor of the Papers: Meaghan J. Brown}

The Papers of the Bibliographical Society of America (ISSN 0006-128x) is published quarterly by the Society, ${ }_{233}$ East 7oth Street, ${ }_{5} \mathrm{P}, \mathrm{New}$ York, NY 10021. Third-class postage paid at New York, NY, and additional mailing offices. POSTMAster: Send address changes to Papers of the Bibliographical Society of America, P. O. Box 1537, Lenox Hill Station, New York, NY 10021.

Subscriptions are available only through membership in the Society $(\$ 65.00$ per year for individuals, $\$ 100.00$ for institutions, and $\$ 20.00$ for students; residents outside the US should add a $\$ 15.00$ surcharge for postage). Back numbers are available from Periodicals Service Company, 11 Main Street, Germantown, NY 12526 (phone: [518] 537-4700; fax: [518] 537-5899; email: psc@backsets.com). claims: No claims for issues will be accepted after six months from date of issue.

Contributions to the Papers may deal with books and manuscripts in any field, but should involve consideration of the book or manuscript (the physical object) as historical evidence, whether for establishing a text or illuminating the history of book production, publication, distribution, or collecting, or for other purposes. Studies of the printing, publishing, and allied trades are also welcome. PBSA is a refereed journal.

Contributors should submit their text in any standard word-processing program. Those preferring to submit electronically should e-mail the editor, attaching the text as a Microsoft Word (*.doc or *.docx) file. When designing tables, charts, and illustrations, please be aware that the $P B S A$ textblock is proportioned 1:1.5.

We follow the Chicago Manual of Style, 16th edition, in matters of general style. In bibliographical collation or pagination statements, contributors should follow the GregBowers formulary (not McKerrow or Gaskell), but in all cases should employ the option of bracketed letters or figures, not italics, to indicate inferred paging or signing (e.g., [27] p. and $[\mathrm{A}]_{4}$, not $27 \mathrm{p}$. and $A_{4}$ ). Our typeface does not always allow clear distinction of italic from roman in isolated figures and letters.

\section{ADDRESSES AND PHONES}

Submissions to the Papers and Books for Review:

David L. Gants, English Department, Florida State University

405 Williams Building, Tallahassee, FL 32306-1580

PHONE: (850) 644-4230 / FAX: (850) 644-0811

E-MAIL: editor.pbsa@bibsocamer.org

Business and Advertising:

P. O. Box 1537, Lenox Hill Station, New York, NY 10021

PHONE/FAX: (212) 452-2710; E-MAIL: bsa@bibsocamer.org

Visit the Society's website at http://www.bibsocamer.org

Printed and published, in part, with monies derived from the George Watson Cole Publication Fund and The Lathrop Colgate Harper, Litt.D., Trust Fund. 

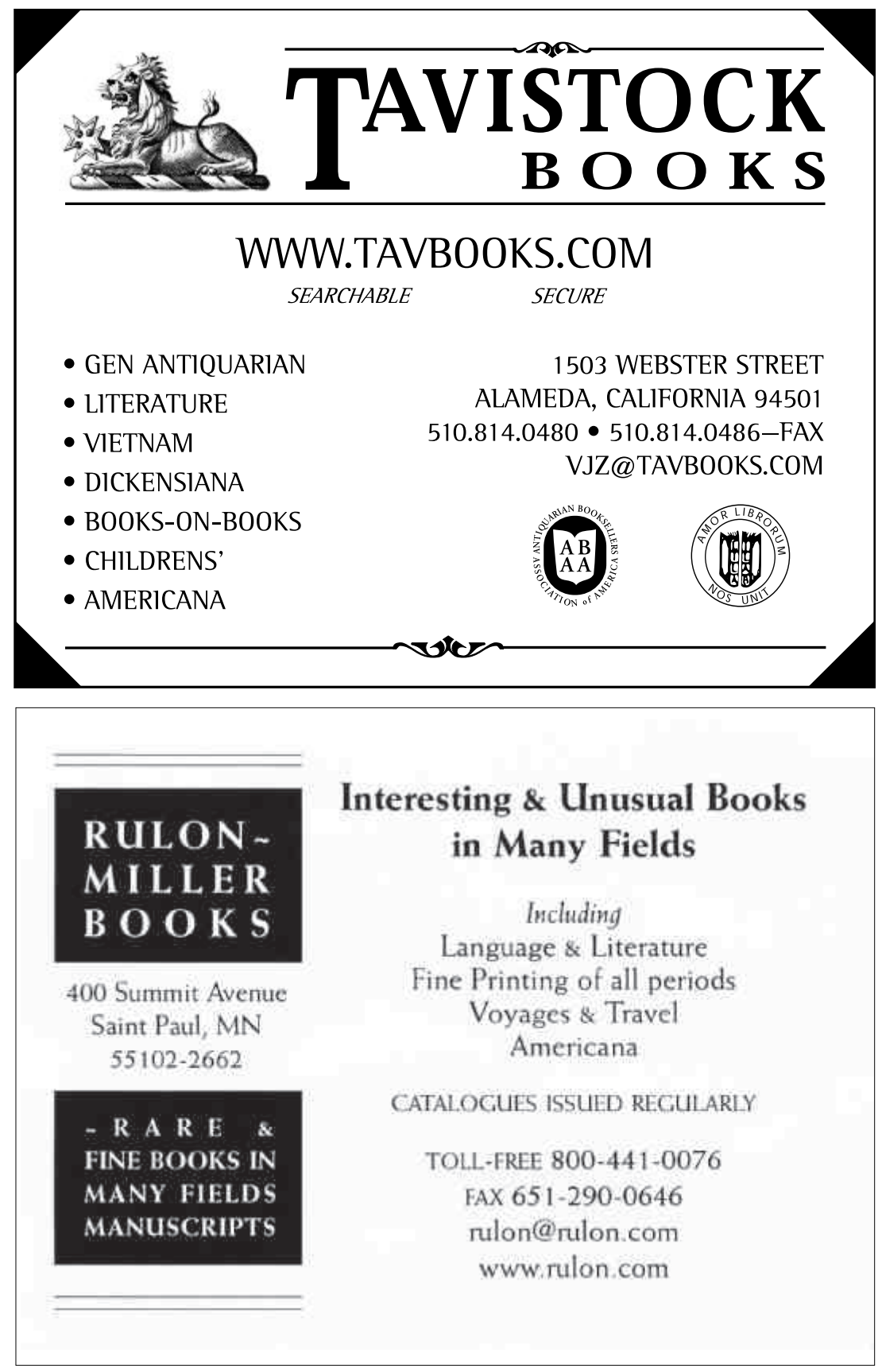


\title{
The Place of Musical Settings in Author Bibliographies, with Examples from Christina Rossetti
}

\author{
Maura Ives
}

$\mathrm{S}$ CHOLARSHIP ON DESCRIPTIVE BIBLIOGRAPHY, including that devoted to the bibliography of music, has little to say about the treatment of musical settings of literary works within bibliographies of British and American authors, and author bibliographies rarely offer a rationale for their inclusion or treatment of musical works. As a consequence, while many author bibliographies include music, no one seems to have thought much about why or how we should represent this material within the confines of our projects. ${ }^{1}$ Since literary bibliographers are primarily interested in the printing and publishing history of literary texts as texts,

1. For a bibliography that does include a detailed discussion of musical settings, see B. C. Bloomfield and Edward Mendelson, W. H. Auden: A Bibliography 19241969, 2nd ed. (Charlottesville, VA: University of Virginia Press, 1972). Bloomfield and Mendelson do not specifically mention musical settings in the bibliography's introduction, except in a sentence explaining that all non-print sections present "difficulties in arriving at satisfactory solutions" for description (xi); however, the headnote to the music section outlines Auden's interest and involvement in music, including his collaboration with Benjamin Britten, and identifies materials excluded from the bibliography or from the music section. It does not explain the rationale for content or format of the section entries, except to explain the treatment of sound recordings.

Maura Ives (Texas A\&M University, MS ${ }_{4227}$ TAMU, College Station, TX 77843) is a Professor in the Department of English and Associate Director of the Initiative for Digital Humanities, Media and Culture (IDHMC) at Texas A\&M. A recent recipient of the Fredson Bowers award, she is author of Christina Rossetti: A Descriptive Bibliography (2011), co-editor of Women Writers and the Artifacts of Celebrity in the Long Nineteenth Century (2012), and articles in venues including PBSA, Textual Cultures, and the Journal of Pre-Raphaelite Studies. 
it is no surprise that author bibliographies often approach musical settings from the perspective of literary scholarship, focusing on the textual content to the exclusion of all but the most basic bibliographical details of the scores themselves. Yet this literary focus has kept us from seeing some things about musical settings that may ultimately be of great interest to literary scholars, as I will show in my discussion of Christina Rossetti's settings in the next section. ${ }^{2}$ Musical settings appear in author bibliographies primarily because they exist as printed matter and include the author's words (or some version of them), but there are additional reasons for including this material, and a serious consideration of those reasons might lead us to make some changes in how we handle musical settings, as would more careful consideration of ways in which printed musical scores differ from other printed materials.

In this essay, I would like to present an argument for musical settings' place in literary bibliography, and to offer suggestions about the content and format of sections devoted to musical settings. Since my work on a descriptive bibliography of Christina Rossetti has led me to this topic, my observations are anchored in the world of nineteenth- and early twentieth-century publishing, a time when it was increasingly common to find literary texts adapted for use as parlor or art songs. I begin by using Rossetti's appearances in music to illustrate some of the reasons why musical settings are of interest to bibliographers and other scholars examining the production, transmission, and reception of literary texts. I then turn to practical matters, continuing with the process of identifying and locating musical settings, and concluding with guidelines for determining the scope, content, and organization of musical settings within author bibliographies. Like most bibliographers who focus on literary figures, I am not a specialist in music bibliography, nor do I claim to have become one in the course of my work. I also do not claim that my own thinking about musical settings or my work on Rossetti's settings is exemplary of anything other than one scholar's effort to wrestle with a bibliographical problem. But because I have made some effort to become familiar with aspects of music printing and publishing that are relevant to, and easily incorporated within, bibliographies of authors, I hope that my contribu-

2. See Joanna Swafford's digital archive, Songs of the Victorians (http://www.songsofthevictorians.com), which demonstrates the exciting potential for digital tools to create new opportunities for literary and other research. 


\section{Musical Settings in Author Bibliographies}

tion will be useful to other literary scholars-including but not limited to bibliographers who wish to incorporate musical scores into their research.

\section{MUSICAL SETTINGS AND LITERARY RESEARCH: THE CASE OF CHRISTINA ROSSETTI}

In their introduction to A Shakespeare Music Catalogue, Bryan N. S. Gooch and David Thatcher provide a brief overview of the value of musical settings for humanities research:

A Shakespeare Music Catalogue will serve a variety of purposes other than its main one of documenting this prodigious amount of Shakespeare-related music. It will enable literary historians and musicologists to gain further perspective on the history of taste, as it reveals which texts have been most popular at any given time over a period of four centuries [. . . ]. It also gives musicologists easier access to the enormous range of Shakespeare compositions, facilitates comparative studies of treatments of the same text by different composers, and allows the tracing of each composer's contribution to Shakespeare music. Literary scholars will now be able to assess Shakespeare's international reputation on the basis of the range and number of compositions inspired by his life and works; theatre historians and directors can obtain valuable clues as to the musical approach that was taken in specific productions. ${ }^{3}$

Shakespeare is exceptional among authors whose works have been set to music, since most have not inspired four centuries worth of musical settings, a listing of which fills five volumes. ${ }^{4}$ But even a brief list of musical settings will open up new possibilities for researchers in literature, music, and related fields by providing answers to basic questions about an author's appearances in music: How many of the writer's poems were set to music? Which poems were most frequently set? What kinds of music were the author's words associated with? What were the target audiences for these compositions? When and how frequently were they set, and by which composers? Who published them, where were they published, and how often were they reprinted? Depending on the level of detail the

3. Bryan N. S. Gooch and David S. Thatcher, Musical Settings of British Romantic Literature: A Catalogue, Garland Reference Library of the Humanities 326, 2 vols. (New York: Garland, 1982), xix.

4. Rossetti's profile, while not unusual for a nineteenth-century poet, is somewhat more modest: my bibliography lists 172 settings through 1899, with additional settings identified after the book went to press. 
bibliographer provides, a listing of musical settings can also indicate the nature of the author's involvement in the creation of the settings, describe the changes that took place in the author's texts within particular settings, and explore the social context of the settings: if, when, where, and by whom were they performed?

Looking at them strictly from the viewpoint of literary scholarship, musical settings provide valuable evidence about a writer's reputation, popularity, influence, and reception. For bibliographers and textual scholars, musical settings are of special interest for several reasons. The republication of poems within musical contexts includes both the creation of separately published librettos to accompany performances of longer works ${ }^{5}$ and the possibility that the score itself will include the poem as a separately printed text, a practice that both emphasizes the text's origin as a literary work and provides an opportunity for textual variants to be created and widely circulated. Sometimes texts of poems are incorporated into a musical document in creative ways, as when Rossetti's "Hope is like a harebell" appears within the cover design of Georgina Schuyler's 1877 setting. Reviews and advertisements for musical settings also often quote the poem's text. ${ }^{6}$ And although one might assume that poems are set to music after they have been published initially in some other form, this is not always the case: musical settings may well constitute the first separate appearance of a poem, as well as its first appearance in a periodical and or anthology. Rossetti's poem "If" (later titled "Hoping against Hope") did not appear in a volume of her poetry until after her death but was published separately by Lady Baker (Augusta Catherine Fitzwygram Baker) as a musical setting in 1874. Reviews of the setting paid particular attention to Rossetti's words: the reviewer in the Graphic found Rossetti's text "morbid," whereas the reviewer in

5. Two of these publications are known to have existed, one to accompany a performance of G. A. Macfarren's cantata for Songs in a Corn-Field in 1869, and another that was available from the publisher of Emanuel Aguilar's 1880 cantata for "Goblin Market" (see Ives, Christina Rossetti: A Descriptive Bibliography (New Castle, DE: Oak Knoll Press, 2011), 258, 265. I have not located any extant copies of either publication.

6. For example, a review of S. M. Downs's "Request," a setting of Rossetti's "Song" ("When I am dead, my dearest") in the periodical Old and New includes "the words," presumably taken from the setting itself, but with omissions and alterations in both text and punctuation (Old and New [July 1874]: 143). 


\section{Musical Settings in Author Bibliographies}

the Musical Standard found fault instead with Baker's "rollicking style," which was "scarcely a right conception of words spoken under somewhat serious circumstances." ${ }^{\prime 7}$ In this instance, the musical settings focused popular attention on an individual poem that, due to its absence from Rossetti's poetry collections, would have been overlooked otherwise. In another example of the potential for a setting to elevate the status of a poem, Rossetti rejected her brother Dante's advice to omit the poem "The Bourne" from The Prince's Progress partly "because it has been set to music very prettily by Alice Macdonald."

The role musical settings might play in increasing the audience for particular poems has rarely been discussed, but Rossetti's decision regarding "The Bourne" suggests that she believed a musical setting could generate enough public recognition of a poem that readers would expect to see it in print. Settings of poems already published may alter the dynamics of reception by keeping poems in circulation well beyond their initial publication and pulling them away from their initial bibliographic, aesthetic, and cultural contexts. As early as 1865 - only three years after the publication of Goblin Market and Other Poems-enough composers had inquired about setting "Up-Hill" and "A Birthday" to make Rossetti term Virginia Gabriel's request to set "Echo" a "pleasing variety." By 1900, "A Birthday" had been set to music over thirteen times; another title from the 1862 collection, "Song" (hereafter referred to by its first line, "When I am dead, my dearest"), soon surpassed "A Birthday" to become Rossetti's most frequently set poem, with over forty-one settings by century's end. 10 "When I am dead, my dearest" had enough currency in the last quarter of the century to inspire the Athenaeum to complain that drawing room music "want[s] more comforting themes" than Rossetti's "world of woe"11 — and also to inspire the authors of popular fiction to exploit the song's popularity and pathos by including scenes in which a protagonist performs it, often in moments of emotional tension or

7. Graphic (23 May 1874): 503; Musical Standard (13 June 1874): 391.

8. Christina Rossetti, The Letters of Christina Rossetti, ed. Antony H. Harrison, 4 vols. (Charlottesville, VA: University of Virginia Press, 1997-2004), 1:243.

9. Ibid., 1:222.

10. Since my bibliography went to press, I have identified additional settings of both poems.

11. "Vocal Compositions," Athenaeum (23 September 1871): 409. 
dramatic crisis. ${ }^{12}$ In Sydney Hodges's When Leaves Were Green, Rossetti is identified as the author of the "words," but the song is identified with its composer, Alice Mary Smith, and the performance serves primarily to emphasize the charm and talent of the singer: "The next moment Miss Venables' voice was thrilling through the room with an intensity of sweetness and pathos impossible to describe."13 The popularity of poems such as "When I am Dead" as lieder insured that Rossetti's early lyrics would continue to shape the popular and critical reception of her career long after she had turned her attention to other poetic forms and to the devotional writing that characterized the last decades of her career. It also seems likely that for poets like Rossetti, the wider audience musical settings garnered has influenced the choice of poems that most frequently appear in later anthologies and selected works.

The ways in which musical settings alter and augment texts and their meanings are obviously of particular interest to literary scholars. The adjustments necessary to fit words with music almost always introduce textual variants: new titles for musical settings are common; words, lines, and entire stanzas may be removed or repeated; meter is frequently adjusted. Text may be rearranged or taken out of context in ways that drastically affect meaning, and substantial portions of the text may be revised, for any number of reasons. An author may or may not have been involved in this process. Although nineteenth-century British copyright law did not permit composers to publish musical settings of texts under copyright without permission, many settings of Rossetti's poems seem to have taken place without the consent of the author or her publisher,

12. The text of the poem, as printed in Rossetti's collection Goblin Market and Other Poems (1862):

Song.

When I am dead, my dearest,

Sing no sad songs for me;

Plant thou no roses at my head,

Nor shady cypress tree:

Be the green grass above me

With showers and dewdrops wet;

And if thou wilt, remember,

And if thou wilt, forget.
I shall not see the shadows,

I shall not feel the rain;

I shall not hear the nightingale

Sing on, as if in pain:

And dreaming through the twilight

That doth not rise nor set,

Haply I may remember,

And haply may forget.

13. Sydney Hodges, "Chapter IX: The Picture Progresses," When Leaves Were Green, in Argosy (March 1895): 262, 268. 


\section{Musical Settings in Author Bibliographies}

Macmillan, and for most of Rossetti's lifetime, British copyright law did not apply to the many American composers who set Rossetti's words. However, when permission was sought, both Rossetti and Macmillan routinely granted it. Even if an author's permission for a musical setting had been sought and granted, the author's role in adapting the text varied considerably.

There are few examples of Rossetti's active participation in the composition of a musical setting, but in 1866 she agreed to "make some verbal alterations in the Birthday, to make it more intelligible when set to music" by Traventi, and she also met with composer Emanuel Aguilar to "settle" the text of "Goblin Market" for Aguilar's cantata - a surprising event, given the extensive textual alterations in the cantata as published. ${ }^{14}$ But Rossetti seems not only to have accepted the idea that some textual changes might be necessary when her poems were set to music, but also to regard words as playing a secondary role to the music itself. Writing to an unidentified female composer (possibly the Countess of Claremont, who had set Rossetti's poem “Up-hill”), Rossetti responded to a problematic alteration in the text by declaring that "words are usually so merely accessory to air, that very likely not one singer in a hundred will even suspect an error." ${ }^{15}$ And when composer Theo Marzials sent her a basket of flowers, Rossetti's response included a similar (and, to contemporary ears, uncomfortably gendered) understanding of the relative contributions of music and text: "May our combination of music $\&$ words make up as faultless a harmony. Yours shall be, as it ought to be, the lordly \& dominant element, so long as mine may hope to be recognized as ladylike \& retiring." 16 But despite her willingness to downplay the role of lyrics within the "harmony" of a setting, she sometimes insisted upon retaining control of the text of her poems. When choir conductor Henry Leslie, in preparation for a performance of George Macfarren's setting of Rossetti's "Songs in a Cornfield," asked permission to print the libretto, she requested that he, "like Mr. Macfarren, [...] favour me by seeing that the text is correctly printed." 17

14. William Michael Rossettii, Rossetti Papers 1862-1870 (New York: Charles Scribner's Sons, 1903), 198.

15. Rossetti, Letters, 4:414. The letter is not dated, and the identification remains uncertain because, while Rossetti refers to an "error" or "alteration" in the text, the only copy of the Countess's setting that I have seen follows the text exactly.

16. Rossetti, Letters, 3:46. The letter is dated only "May 30," and addressed to "Mr. Marzials." Although Harrison identifies the recipient as Frank Marzials, Theo is a more likely choice.

17. Rossetti, Letters, 1:316. 
Musical settings of Rossetti's work incorporate a wide range of textual alterations. In some instances, the changes are drastic. In January 1882, the Boston children's periodical Wide Awake published a musical setting by George Osgood, titled "A Christmas Carol," and based on Rossetti's "It is Finished." ${ }^{18}$ The poem recounts the life of Christ, including several stanzas about the Crucifixion, and ending with the speaker's hope of reunion with Christ at the Judgment. To transform this into a Christmas carol, Osgood omits the stanzas that refer to the Crucifixion and Judgment and uses repetition to emphasize the speaker's self-representation as a "little one," perhaps to increase the poem's appeal to the periodical's young readers. Other Rossetti poems with religious content underwent similarly extensive changes, in keeping with the tendency of hymn texts to be altered according to the practical and theological needs of their users. In Sought Out Songs for Christian Workers (1888), the evangelist A. B. Earle included C. B. J. Root's setting of Rossetti's poem "Weary in Well Doing." Root also contributed two new stanzas, which shifted the poem's tone from one of weariness to one of peaceful yielding to the will of God. ${ }^{19}$

Even when the text of a poem set to music remains unchanged, musical settings introduce new bibliographical codes by juxtaposing words with the visual elements of musical scores, including the framework of the score itself and other paratextual features common to printed music. ${ }^{20}$ Consider, for example, the popularity of lithographed sheet-music covers in the mid-nineteenth through early twentieth century. A cover design can change one's response to the words of a song: for example, a 1901 printing of Theo Marzials's "My Love is Come" (a setting of Rossetti's "A Birthday") appeared with a woman's portrait on the cover. ${ }^{21}$

18. "A Christmas Carol," Wide Awake (January 1881): 74. "It is Finished" had been published in Rossetti's collection A Pageant and Other Poems (London: Macmillan; Boston: Roberts Brothers, 1881).

19. Ives, Christina Rossetti, 15.

20. Jerome McGann's term bibliographical codes refers to the influence of nontextual and nonliterary elements of documents upon literary meaning (The Textual Condition [Princeton, NJ: Princeton University Press, 1991], 60). George Bornstein expands the concept to include "contextual codes," created through the juxtaposition or sequencing of literary texts ("What is the Text of a Poem by Yeats?" in $\mathrm{Pa}$ limpsest: Editorial Theory in the Humanities, ed. George Bornstein and Ralph Williams [Ann Arbor, MI: University of Michigan Press, 1993], 179).

21. Marzials, My Love is Come, supplement to the New York Sunday Press (22 September 1901). 
Although Rossetti's poem does not specify the gender of the speaker, those who viewed the music's cover might assume either that the portrait represents the singer, or the singer's beloved, with the latter assumption perhaps borne out by the vocal range of the setting and its overall tone. In any event, the visual elements of the setting alone would prompt those who saw the music to specify the gender of the singer/speaker in a way that Rossetti's poem did not support. Often there is also valuable contextual information on music covers, such as dedications to contemporary performers, that helps us to understand how a particular song was presented to its audience - or at least how that song was marketed, since, as Derek Scott explains, publishers paid performers to "promote their music," and printed singers' names on sheet music covers to "encourage sales." 22

However, as interesting as the score and its paratexts are to scholars, most of the people who hear popular songs never see it (or its cover). Music exists as performance, and words that are performed as music differ aesthetically from words read silently or spoken aloud. What we might term the "aural codes" of poems set to music also change the way that we understand those words. In writing of musical settings of Walt Whitman, Kathy Rugoff observes that when musicologists study a poem in a musical setting, they notice

connections established by the composition's melodies, harmonies, and rhythms. They also may observe that parts of the text are highlighted and allied by consistencies in instrumentation, and textual passages are connected each time they are sung by the same voice or voices. Thus, the reading of the literary text by musicologists is informed by images and phrases stressed by a composer. Musical settings are, on one level, a reader's response to a poem and afford the attentive listener not only the pleasure of the musical text but also an interpretation of the written text. ${ }^{23}$

Lawrence Kramer also recognizes that "a song . . . is a reading, in the critical as well as the performative sense of the term: an activity of interpretation that works through a text without being bound by autho-

22. Derek B. Scott, Sounds of the Metropolis: The 19th-Century Popular Music Revolution in London, New York, Paris, and Vienna (New York: Oxford University Press, 2008), 32 .

23. Kathy Rugoff, "Three American Requiems: Contemplating "When Lilacs Last in the Dooryard Bloom'd," in Walt Whitman and Modern Music: War, Desire, and the Trials of Nationhood, ed. Lawrence Kramer (New York: Garland Press, 2000), 136-37. 
rial intentions." ${ }^{24}$ Music critics understand these points all too well, as Compton Mackenzie illustrated, with characteristic candor, in a 1931 review of Sir Landon Ronald's setting of Rossetti’s "When I am dead, my dearest":

I am not often tempted to pitch a record out of the window, but when I heard Mr. Hislop begin to yell When I am dead, my dearest I restrained myself with difficulty [...] Sir Landon Ronald [...] presumably endorsed "When I am dead, my dearest" being sung fortissimo, "sing no sad songs for me" forte, "plant thou no roses at my head" piano, and "nor shady cypress tree" forte to fortissimo. Why should roses be planted softly and cypresses loudly? The answer is because the roses are planted in the third line of the first verse, and in the third line of the second verse softness will be required to sentimentalize "and if thou wilt, remember." ... The third verse is fortissimo almost throughout, and the poor nightingale ends on such a loud note of pain that one suspects she was egg-bound. ${ }^{25}$

To bring the discussion back to its main focus, my review of Rossetti's musical settings identifies two areas of scholarly interest that offer a rationale for including musical settings among the primary materials for literary bibliography and textual scholarship. The first area of interest is grounded in the text itself: bibliographers might wish to include musical settings because of their influence on a text's history, including its publishing, distribution, interpretive, and reception history, often across national borders and languages, and because musical settings may include textual variants not found in non-musical formats. The second area of interest is more broad: musical settings are valuable to bibliographers and other scholars because of the role they might play in expanding the author's reception and popularity, as well as in revealing the wider historical, aesthetic, and cultural contexts of the author's work, including networks of artistic exchange and social interaction such as performances. The work of the bibliographer in locating, identifying, and describing an author's musical settings allows scholars to gain some sense of the author's place within the networks of musical publication and distribution and provides an invaluable platform from which further work can proceed.

\section{FIRST STEPS: LOCATING MUSICAL SETTINGS}

Almost all of the decisions that a bibliographer will need to make about the treatment of musical settings within a specific bibliography

24. Lawrence Kramer, Music and Poetry: The Nineteenth Century and After (Berkeley, CA: University of California Press, 1984), 127.

25. Compton Mackenzie, "Editorial," The Gramophone 9, no. 97 (June 1931): 2-3. 
depend upon the number of settings that must be considered. As the example of Shakespeare makes clear, for some authors there can be hundreds, even thousands, of musical settings - enough to merit treatment in a volume of their own. Depending upon the author and the time period, there may be far more settings than one initially expects, and while it is becoming easier to locate settings, a successful search-that is, a search that will eventually yield something close to a complete list of the author's appearances in music - still demands time, patience, perseverance, and a good bit of luck.

An author's correspondence, publishers' archives, and other primary sources relevant to an author's publishing history may offer some insight into the nature and extent of the author's settings, but they are not likely to present anything like the full picture of the author's representation in music. A better, though still limited, initial estimate of a given author's musical settings can be derived from the few reference works focused broadly on the setting, which are of more use to author bibliographers than general music reference sources, which tend to focus only on the most well-known composers and settings. The essential starting places for settings of nineteenth-century British literature are Bryan N. S. Gooch and David S. Thatcher's catalogues: Musical Settings of British Romantic Literature (1982), Musical Settings of Early and Mid-Victorian Literature (1979), and Musical Settings of Late Victorian and Modern British Literature (1976). ${ }^{26}$ The Gooch and Thatcher volumes each cover settings from the author's lifetime through the publication of the catalogue. For American authors, Michael Hovland's Musical Settings of American Poetry: A Bibliography (1986) provides a similar starting place for research. Hovland includes ninety-nine nineteenth- and twentiethcentury authors, as well as settings through the date of the bibliography's publication. Although these listings are all limited by the scope of the volumes and by the search tools and strategies available at the time that they were published, they are still extremely valuable resources. Art song indexes, including Judith E. Carman, William K. Gaeddert, and Rita M. Resch's Art Song in the United States, 1759-2011, and Emily Ezust's The Lied, Art Song, and Choral Texts Archive are also helpful, though the former, given its focus on helping "teachers and students in the selection and performance of American song," eliminates work that is unsuitable

26. For full publication details of all resources mentioned in this article, see Appendix below. 
for its audience. ${ }^{27}$ Finally, Carol June Bradley's Index to Poetry in Music will help to identify the major composers who have set an author's work, but here also, the list of composers is selective, taking into account not only the quality of the composers and texts but the availability of their work.

These reference works must be supplemented by thorough searches of national library catalogues and the catalogues of libraries focused upon music or housing significant collections of music. For music printed in the United States, a visit to the Library of Congress's Music Division (including consultation of copyright records for music published in the United States) is essential, as is a visit to the British Library for music printed in the United Kingdom and settings of British authors, keeping in mind, of course, that settings of British texts were published in the United States and vice versa. Beyond these first stops are the many academic and public library collections, some of which I have listed in the Appendix at the end of this essay. Printed catalogues of major collections, such as those of the Boston Public Library and the New York Public Library, are necessary not only to make use of the specific collections they represent, but also to establish the basic outlines of the author's setting history. However, because libraries often struggle to maintain and update catalogue records for holdings, no one source of information about holdings is necessarily complete. To fully search the Boston Public Library's collection, for example, one must not only examine the Dictionary Catalog of the Music Collections, but also the print First Supplement to the Dictionary Catalog of the Music Collection, two additional supplements, the "in card catalog form," and an online catalogue ("Use of the Music Department Collections"). Visiting or contacting libraries directly to inquire about holdings may be necessary to discover valuable material in collections that are not fully catalogued or available online.

To search library catalogues effectively, the bibliographer must also remember that catalogue records often do not include the name of the author of song lyrics, and even catalogues that do include this information will probably not be consistent, if only because authors' names do not always appear on published scores. Searching by poem title is also of limited value because composers often give poems new titles when they are set to music. There are various ways to compensate for this problem, such as searching library catalogues and full-text databases by names of composers known to have set work by the author, searching author/title

27. Carman et al., Art Song, ix. 


\section{Musical Settings in Author Bibliographies}

sources by first lines of poems (some composers use a poem's opening words as the title), and searching by known song titles (since composers may discover a text not from the author's publications but from other settings, from which they adopt the title as well).

The increasing availability of digital archives and full-text databases has done much to make the task of identifying and locating musical settings easier. Of particular value are indexes, full-text databases, and digital archives that include newspapers and periodicals, including those focused on music periodicals, such as RIPM (Retrospective Index to Music Periodicals, which covers 1766-1962), International Index to Music Periodicals (1874 to present), Music Index (1970 to present), Canadian Music Periodical Index (nineteenth century to present), as well as those wider in scope such as British Periodicals and American Periodicals. Although it can be especially helpful to search periodicals that focus on music, many other publications regularly include reviews and commentary on recent music publications and performances as well as announcements of, and advertisements for, new publications. Without digital tools that allow for full-text searches, musical settings published in periodicals can be nearly impossible to find because indexes and tables of contents often list musical settings under the names of composers rather than those of the authors who contributed the lyrics. For example, Osgood's setting of Rossetti's "It is Finished" is listed in the table of contents for Wide Awake under "Music," instead of under Rossetti's name or her original title. Thus microfilm collections, even those focused on music such as ProQuest's Nineteenth Century American Music Periodicals 1800-1900, are often of limited value for the purpose of discovering information about musical settings, unless one has the time and patience to work through them page by page.

But periodicals are not the only place where information about musical settings, or settings themselves, can turn up: any contemporary print source might be of use, making any and all resources that include full text, from Google Books to more specialized commercial databases such as Early English Books Online (EEBO), worth searching. Large digital archives can sometimes help with the especially difficult task of locating musical settings that were not published separately. While there are several print and digital song indexes that should also be consulted, many (such as Gary Lynn Ferguson's Song Finder: A Title Index to 32, ooo Popular Songs in Collections, 1854-1992, the Oberlin Song Index, and others) are limited by not allowing users to search by the name of the librettist. 
A number of digital resources focused on music are of special value to scholars in search of musical settings. Although The Index to Printed Music: Collections and Series has a limited range (it leaves out settings that have not found their way into "sets or series that contain multiple pieces"), it is searchable by poet. ${ }^{28}$ Many libraries are also creating digital archives and search tools for sheet music collections. In addition to The Library of Congress's Music for the Nation: American Sheet Music, 1820-1860 and 1870-1885 and Historic American Sheet Music, 1850-1920 are many other digital archives based on library collections, such as African-American Sheet Music, 1850-1920 from the John Hay Library, Brown University. Digital collections and other resources focused on authors may also include music, as does the Harry Ransom Humanities Research Center's Edgar Allen Poe collection. Some commercially produced databases, such as African American Music Reference, also include lyrics and sheet music.

For some authors (including Rossetti), the search for musical settings must also extend to the use of poems in hymns. Not all hymnals include music, and the question of what to do with texts published in hymnals is one that I will take up later. But even when hymns appear as text only, they may or may not appear with the author's name, and the likelihood of significant variations in the title and text can make them even more difficult to track. John Julian's A Dictionary of Hymnology has long been a standard reference source for hymns, with listings for a number of nineteenth-century and earlier poets whose work appeared in hymnals. The forthcoming Canterbury Dictionary of Hymnology, edited by J. R. Watson and Emma Hornby, is intended to update and expand Julian's work. Perhaps the single most useful source, however, is the Dictionary of North American Hymnology (DNAH), now searchable online, including a person search. A $D N A H$ search yields lists of texts (identified usually by first line), tunes, and hymnals, as well as a chart showing the author's inclusion in hymnals over time; for some hymnals, digital page images are also included. While $D N A H$ is focused on American publications, the list of texts provides a starting point for searching hymnals and anthologies published elsewhere. It may also be worthwhile to investigate HymnQuest, a software package that indexes 465 twentieth-century hymnals and allows searching by first lines and authors.

28. See the review by Jean Harden in Notes: Quarterly Journal of the Music Library Association 67, no. 4 (June 2011): 793-98. 


\section{Musical Settings in Author Bibliographies}

\section{MUSICAL SETTINGS WITHIN THE AUTHOR BIBLIOGRAPHY}

\section{General Concerns}

While a detailed discussion of the descriptive bibliography of music is beyond the scope of this paper (and of my own expertise), those who wish to include music will benefit from learning the basics of music printing and publishing within the time period of their authors. ${ }^{29}$ Nineteenthcentury music publishing employed the same basic technologies as other printing: letterpress, stereotype and electrotype plates, engraved and/or "punched" plates, and lithography. Given those similarities, music and book bibliographers often go about their business in similar ways. ${ }^{30} \mathrm{At}$ the same time, there are details specific to the music business that are important for author bibliographers to know. For example, printed music often contains plate or publisher numbers, which can be helpful in identifying subsequent reprintings from those plates, and the copyright status of printed music often differs from that of books. ${ }^{31}$

David Hunter et al. have included recommendations for descriptive bibliographies in the "Music Library Association Guidelines for the Preparation of Music Reference Works." Many of them are familiar (for example, transcribing or reproducing title pages, describing the physical structure of music, and indicating the date of printing). The guidelines for providing information on the "intellectual content" of music are less so: the bibliographer should include not only "the conventional title, the opus or other identifying number, the author or source of verbal text," but also "a full list of performing forces, the duration of each movement, the date and place of composition," and information about the "first performance (place, date, performers, references to reviews and advertisements); and on dedicatee(s)." 32

Though not all of this information is necessary for every author, bib-

29. One might begin with D. W. Krummel and Stanley Sadie's Music Printing and Publishing (1990), and Krummel's The Literature of Music Bibliography (1992), which covers scholarship in bibliography, publishing, printing, and related topics.

3o. For an overview of music printing in Britain through the early twentieth century, see William Gamble, Music Engraving and Printing: Historical and Technical Treatise, Da Capo Press Music Reprint Series (New York: Da Capo Press, 1971).

31. See, for example, the brief but interesting summary of nineteenth-century music copyright and performing rights in Scott, Sounds of the Metropolis, 31-34.

32. David Hunter et al., "Music Library Association Guidelines for the Preparation of Music Reference Works," Notes: Quarterly Journal of the Music Library Association 50, no. 4 (June 1994): 1332. 
liographers should at least become familiar with the range of bibliographical and other details relevant to musical scores, decide which of those details to include in the bibliography, and explain their decisions to their readers. Unfortunately, with few exceptions, author bibliographies that include music offer little, if any, explanation, either about the rationale for the music's inclusion or the decisions that inform its presentation. In most cases it is impossible for users of these bibliographies to understand why music is included, much less why the bibliographer supplied some kinds of information about musical publications but not others. Of course, there may be reasons for bibliographers to limit the amount of detail about musical publications in author bibliographies. A user of an author bibliography may not be seeking such specialized information; others may not have the background to use it. A bibliographer must weigh the value of providing that information against the need to explain it to readers unfamiliar with music publication. The bibliographer's own expertise with music (or lack thereof) also comes into play. The main point, however, is that the degressive principle should not automatically be applied to music, or to any other feature of a bibliography, unless the bibliographer is certain that an abbreviated description is either necessary or appropriate, given the circumstances peculiar to the author.

Perhaps the most important element informing the decision of whether or not to include music is the bibliographer's understanding of the nature, relevance, and status of musical settings, both as artifacts and as works of art. Four observations, to me, seem crucial:

1. A bibliography that acknowledges musical settings as works of art in their own right will have more to offer users than one that implicitly represents musical settings as derivative works that have value only because an author's words have been incorporated.

2. A musical setting is a new artistic creation, or, as Lawrence Kramer terms it, a "de-creation" that "appropriates the poem by contending with it, phonetically, dramatically, and semantically." 33 Printed music also situates the text within a new visual and material format that has its own interpretive, paratextual, and bibliographic conventions, any or all of which may have a profound impact on the text, even if its wording and punctuation remain unchanged.

3. By carrying an author's text to new audiences, musical settings can also have a distinct, and often underappreciated, influence upon the 33. Kramer, Music and Poetry, 127. 


\section{Musical Settings in Author Bibliographies}

reception of a writer's work.

4. Musical settings are by definition collaborative works, involving at least two creators (author and composer). While we can expect most users of an author bibliography to be primarily interested in the author's contribution, some might want to study the collaboration itself, and still others the composer or other creators, such as graphic designers responsible for a cover illustration.

One can debate any or all of these observations. But recognizing only the essential point - that musical settings differ in important ways from other printed texts - will prompt us to think more carefully about the limits we set for their inclusion and representation, and encourage us to be especially aware of the consequences for scholarship that those limits might bring.

\section{PRACTICAL MATTERS}

Although the process of constructing a bibliography involves numerous practical decisions about what to include, how to organize it, and how best to integrate its content with other sections, many aspects of the decision-making process are complicated by considerations unique to music.

\section{Scope and Definition}

A. Definition of Musical Setting: Since a score-the written representation of a musical work - can exist in manuscript or printed form, the bibliographer must decide whether to include both manuscript and printed music. Manuscript settings may be especially important if they are the work of a famous composer, or if they exist in conjunction with documented performances. If a large number of printed scores exist, manuscript settings as a class may take on less importance, though exceptions can be made.

Bibliographers must also be careful to distinguish among written musical scores, performances (with or without extant scores), and recordings of performances, and, if all of these materials are included, the bibliography must present them in ways that illuminate connections among them without creating confusion or obscuring important differences in format and content. Hagstrom and Morgan's bibliography of James Ingram Merrill includes a section titled "Musical Settings of Poems and Prose," which "lists compositions in which poems by James 
Merrill form the lyrics or have been the program for a composer's work," including "commercially published and other works," and "[p]remiere performances and recordings ... when known." 34 Slightly less than a third of the Merrill settings exist as published scores; the rest are most often known because of performances or (less often) sound recordings. These varied artifacts and information sources pose many challenges, but Hagstrom and Morgan could have dealt with them so as to minimize confusion. It is hard to understand how they could claim that the section's entries are "listed chronologically by composition date" when most are in fact listed by date of their premiere performance, even if that performance took place after the score was published. The irony here is that using performances as the primary way of organizing the entries in a section that combines scores, recordings, and performances makes sense, establishing a consistent basis upon which to organize a diverse set of items. But because they focus on (in most instances, unknown) dates of composition and not on the artifacts that convey the composed scores, the entries can be difficult for readers to decipher. Entries include the composer's name and the work's title (which, if it is the same as a Merrill poem, appears in all capital letters), sometimes followed by a "Scored for" statement listing vocal range, instrumentation, commissioning body, and (in all but three entries) concludes with the dates and locations of the premiere performance and names of the performers. Sound recordings and published scores are mentioned in "Note" fields. In some instances where neither a recording nor a published score is mentioned, there is a note that reads "unpublished," but often not, an inconsistency that leaves the status of the score uncertain. The very abbreviated information for recordings and published scores (usually including nothing more than place of publication and publisher) is unsatisfactory in several respects: there is no mention of LP jacket contents or materials accompanying a $\mathrm{CD}$, of the length of the setting (in duration, for sound recordings; in pages, for scores), and no way to know whether the "scored for" statements earlier in the entry are consistent with the music as recorded or the score as published. It is also impossible to tell whether the information in the entries is taken from published settings, reviews of performances, LP or CD liner notes, or elsewhere: no sources (reviews of performances, handbills, programs) are cited, other than information "always referenced in the program notes," and no locations are provided for published scores, recordings, or other materials that were clearly con34. Hagstrom and Morgan, James Ingram Merrill, 247. 


\section{Musical Settings in Author Bibliographies}

sulted, such as the "program notes."

B. Words without Music: What should a bibliographer do with publications that do not include musical scores? Although hymnals often include no music, there is no doubt that the texts within them were intended to be sung. In my own bibliography, I could easily have placed them in a section for publications in anthologies, especially since Rossetti's work often appeared in collections of religious writing that also included hymns. However, while it is possible to read hymnals as anthologies, placing them among such literary assemblages makes it more difficult to trace a particular poem's publication history as a hymn, whether published with music or not, and obscures a writer's career as a hymnist. To deal with the often-blurry distinctions between hymnals proper and collections of religious poetry, I placed all hymnals, with and without music, in a subsection of the bibliography's music section, and all collections of religious poetry that were not clearly intended for use as hymnals in the anthology section, cross-listing them in the headnote to the hymnal subsection. I differentiated hymnals from religious anthologies by several means. Hymnals almost always indicate how the words align with the music, either by a meter designation derived from syllable counts (in which a four-line stanza of eight syllables would be represented by 8. 8. 8. 8., or "Long Meter"), or a tune name, either of which is likely to appear at the beginning of a hymn. If no metrical notation appears in a book, the preface or introduction will almost always state whether a book is intended to be sung or read.

Librettos pose a similar problem. In addition to providing the text of a musical setting, librettos may also offer a number of details about specific performances. These "little books" might be placed among an author's separate publications, within the music section, or both, depending on the number and characteristics of the librettos. However, those that contain performance details might best be placed with the relevant musical scores, so as to take full advantage of their role in documenting performance history and to avoid duplicating this information.

C. Words with Music: An author's text may appear within a musical setting, either within the score proper or "as text," that is, printed separately so that it can be more easily read as a literary work. While there is no reason to create separate entries for words as text, their presence can easily be noted within entries for musical scores.

D. Music without Words: Sometimes composers create music that is 
dedicated to an author, or related in some other way, without including the author's words. Alexander Smith's bibliography of Frank O'Hara includes three examples, each slightly different in its reference to the poet. Ned Rorem's "In Memory of My Feelings," part of his Eleven Studies for Eleven Instruments, "credits FOH [Frank O'Hara] as the source of the title” but does not include O'Hara's text; Ben Weber's Prelude and Nocturne is "Dedicated to Frank O'Hara," as is Morton Feldman's instrumental composition "For Frank O'Hara." 35 Smith places all three of these items in "Section G. Artwork and Music Relating to Frank O'Hara," instead of in the music section, with no cross-listing. Clearly there are significant differences-aesthetic and material-between a piece that incorporates an author's words and one that merely references the author or the author's works, but it is less clear whether that difference should overrule the fact that scores including the author's text and those relating to the author in other ways are all still scores and might be better presented together. As it happens, the composers in question (Rorem, Weber, and Feldman) also composed one or more musical settings of O'Hara's work. In such a case, one should consider grouping all musical compositions together so that users of the bibliography can more easily chart the influence of O'Hara in its various forms on these composers, especially since the three works mentioned above are otherwise all but lost in a section primarily focused on visual art: of the seventy-nine items included in "Artwork and Music Relating to Frank O'Hara," only three are musical compositions.

E. Authorial Involvement: While modern musical settings are unlikely to be published without the permission of the author, earlier authors may or may not have known about, approved of, or participated in the creation of a musical setting, and ascertaining that a particular setting had the author's cooperation can be difficult, depending on the extent to which the relevant correspondence or publishers' records survive. Given that musical settings interest us in part because they present the author's work in a new context and to new audiences, it seems counterproductive to exclude settings based on whether the author granted permission for publication, and only one of the author bibliographies I have examined does so. ${ }^{36}$ Yet some circumstances might merit a narrower focus: if an

35. Alexander Smith, Jr., Frank O'Hara: A Comprehensive Bibliography (New York, London: Garland Publishing, 1979), 237, 238, 241.

36. Crandell's Ogden Nash excludes "published poets set to music without Nash's collaboration" (xi), but no exclusions are mentioned in either of Crandell's later bibliographies of Tennessee Williams and Arthur Miller. 
author collaborated frequently or intensively with one composer, or if an author composed both words and music, one might limit the list to include only settings in which the author was directly involved, or at least highlight the subset of settings that show a greater than usual level of authorial participation.

F. Chronological Limits: If the subject of the bibliography is no longer living, the bibliographer must decide whether the list of settings should include posthumous compositions. The number of settings within Rossetti's lifetime was large enough to convince me it would not be feasible to extend the music section much beyond Rossetti's death in 1894; by restricting my comprehensive list to the nineteenth century, I was able to include nearly forty additional settings, which gave users some sense of the continued interest Rossetti's work would hold for later composers. However, I also included post-1900 settings that focused on important works within Rossetti's poetic canon (for example, "Goblin Market"), and on works that became especially popular among later composers (poems from Rossetti's collection Sing-Song, and "A Christmas Carol," better known by its first line, "In the Bleak Mid-Winter"). Other bibliographers might choose different ways of demonstrating an author's or a text's popularity with composers: one might imagine limiting the music section to a single, frequently set text, for example, or emphasizing settings that were often performed or recorded.

In addition, it may be necessary to decide whether one will list alternate arrangements or later editions of particular compositions, or only the original composition.

G. Managing Large Numbers of Musical Settings: Although chronological limits will sometimes be sufficient to reduce the total settings to a manageable number, for some authors it may be necessary to find other or additional ways to reduce the number of items in a list.

\section{Structuring the Music Section}

A. Timing: While the bibliographer will probably begin to record at least some information about musical settings early on, there is an advantage to deferring focused work on them, including decisions about their placement within the bibliography, until after the rest of an author's publishing history has been established. Because musical settings are usually (though not always) created after a text is published in a book or magazine, having a solid grasp of its publishing history will make 
it easier to deal with the variations of title and textual content that are common in the world of musical settings and to identify and evaluate the overall patterns of textual transmission between the two genresinformation that will help the bibliographer to decide how they fit into an author's overall reception history.

B. Separate Sections for Music: To assist users in locating musical settings, it is almost always preferable to place them in a separate, readily identifiable section rather than putting them in a catch-all category, unless there is a very small number of settings that does not present any special complexity (though one might argue that a separate section, however brief, is useful because it prevents a small list from becoming buried within a larger one). Combining musical settings with sound recordings and performances is a more complicated issue, as I have already indicated. A single chronological list of musical items can help users to investigate the relationships among them: How often were settings performed but not published? Which settings were most often performed or recorded? But in some instances such a list can also be cumbersome, and if the nature of the different items is not clearly identified, it can be confusing and time consuming for users to find the entries that interest them.

C. Subcategories within the Music Section: When bibliographers establish separate sections for musical settings, they should also consider whether to create subcategories within those sections. Because there are important distinctions to be made among separately published settings (such as sheet music), settings within collections (songbooks or hymnals), and settings within periodicals, there may be some benefit from subdividing the musical settings section by genre so that these distinctions are easier to identify and study. But even if a single, chronological list is maintained, there are ways to distinguish among genres and indicate important relationships among them. One way (which I adopted in my own work) is to offer the most detailed treatment to separately published works and provide less detailed descriptions of other forms of publication unless special circumstances dictate otherwise.

Other strategies to help users locate musical settings include crosslisting entries so users can track texts across formats. This is especially important if longer musical works are listed as separate publications. In Bloomfield and Mendelson's W. H. Auden: A Bibliography 1924-1969, some settings such as Our Hunting Fathers, a "symphonic cycle" composed by Benjamin Britten with words by Auden, are placed in Sec- 
tion B ("Works Edited, Translated, or Having Contributions by W. H. Auden"), while others remain in Section S, ("Musical Settings of W. H. Auden's Verse"). Although Bloomfield and Mendelson do not cross-reference here, they do include a list of the relevant items in B in the headnote to $S$ (but without explaining why those particular items were placed elsewhere). Librettos might be placed with other separate printings, as George Crandell does with Lord Byron's Love Letter in his bibliography of Tennessee Williams, keeping the score itself in the music section ${ }^{37}$ and cross-listing the two by providing a note to each entry. Alternate titles and names of composers, arrangers, and other creators of the musical setting should also be included in the bibliography's general index.

D. Organizing Entries: Every organizational system has advantages and drawbacks. Chronological arrangement by year of publication or composition is most useful if the bibliographer wants to draw attention to the relationship of this category to others, and to help readers spot patterns within the publication history of the settings themselves (most bibliographies follow this system). Organization by composer is helpful if the bibliographer wishes to emphasize clusters of settings by the same composer (as in Bloomfield and Mendelson's bibliography); organization by title shows which of the author's works composers have found attractive. Since any of these or other arrangements emphasize some aspects of the entries at the expense of others, bibliographers should also create devices to minimize the inherent limitations of their chosen scheme, for example by highlighting less obvious publication patterns or frequently set titles in the introduction, or through appendices, indexing, or cross-listing.

\section{Composing Entries for Musical Settings}

In my bibliography, all music entries include the title of the setting (if different from Rossetti's title), publication information (including plate or publishers' numbers), locations of extant copies, and the phrase "not seen" for items that I did not examine. When I was unable to locate copies of settings identified through contemporary correspondence, advertisements, or reviews, I provided the source citation and any additional information in a note. Employing a basic template helps the bibliographer ensure consistency among entries, which are likely to vary considerably in other ways, as discussed below.

37. Crandell, Tennessee Williams, 124, 556. 
A. Identification and Location of Copies Examined: Although most entries will include some common categories of information, entries for musical settings are complicated by problems of access to source materials. Many libraries will provide scans or photocopies of music not under copyright, although some will refuse such requests. The situation with copyrighted music is more complicated. Section 108(h) of the US Copyright Act provides exemptions allowing libraries to reproduce copyrighted material for patrons but specifically excludes nonverbal works, including music. The Music Library Association has pointed out Section 108(f) (4), which states that "Nothing in this section ... in any way affects the right of fair use," but some libraries may still be reluctant to provide copies or allow materials to circulate through interlibrary loan. ${ }^{38}$ Given this situation, bibliographers who wish to consult music under copyright, especially works in print and available for purchase, will likely need to do so in person. Even when reproduction services are available, however, photocopy and scanning charges can quickly mount. Consequently, a bibliographer should expect to include at least a few (and quite possibly many) settings that the bibliographer cannot personally examine. Thus it is essential a bibliography provide location information for all examined and unexamined copies, so that those who have an interest in a particular setting can see it for themselves or contact the library holding the copy upon which the bibliographer's entry is based. Readers also need to know which entries are based not on the bibliographer's examination of scores but rather on secondary sources such as library catalogue records.

B. Names and Titles: The length and content of music entries can and should vary for many reasons, such as the special characteristics of an item and its importance in the writer's canon. Names and titles provide one frequent source of variation as well as confusion. Every musical setting entry should include at least one, and sometimes two, titles- the title given by the author to the literary work being set (if any), and the title given by the composer to the musical setting - and bibliographers need to clearly differentiate between them. In order to ensure that users of my bibliography knew which title appeared on the printed score, I first identified each setting by poem title (which appeared, in bold face, along with composer name and publication date at the beginning of the

38. See the "Statement on the Copyright Law and Fair Use in Music," http://copyright.musiclibraryassoc.org/Resources/CopyrightAndFairUse. 


\section{Musical Settings in Author Bibliographies}

entry), followed by the setting title (if different) within the entry proper, eliminating any possible confusion between the two. ${ }^{39}$ Conversely, one might also begin the entry by citing the printed music, starting with the composer's name and the setting title, and identifying the literary works in a note.

When composers draw upon a collection or sequence of poems, using the collection title as the title for their setting, it is especially important for the bibliographer to determine whether the setting includes the text of the entire collection or sequence, or only part of it. Poems from Rossetti's Sing-Song (1872, expanded in 1893), a collection of short pieces for children, were set to music multiple times (beginning with Mary Grant Carmichael's 1884 setting of twenty-seven poems). While many of the settings (including Carmichael's) retain the title Sing-Song, none includes the entire contents of the book. In these entries, I found that it was neither aesthetically pleasing nor especially helpful to begin with a full list of the Rossetti titles included in each setting. Instead, I used Rossetti's book title and provided subheadings within the entry for each of the set titles, which also allowed me to more easily represent musical differences among the settings.

Creator names can also present difficulties. The composer's name is almost certain to appear on the cover of sheet music or songbooks as well as on the first page of the score proper: the bibliographer should check both locations, noting any differences. An author's name is less likely to appear in either place, but it is especially important to document whether or not it appears on the setting, and how it appears, noting misspellings, initials in place of given names, and other variations. This information is valuable both as a means for readers to locate and identify the setting and as a gauge of matters such as the extent to which the author's reputation was used to market the setting - bearing in mind, however, that its placement on a sheet-music cover may not be determined on an individual basis. (For instance, all music printed in a particular series or style might share a common cover design which may or may not include a spot for the librettist's name.)

C. Music: At some point in the entry for a musical setting, the bibliographer needs to account for the special features that characterize musical scores. For items that I could examine or for which trustworthy digital

39. The first line can be used for untitled poems; see, for example, George J. Firmage, E. E. Cummings: A Bibliography (Westport, CT: Greenwood Press, 1960). 
images or photocopies were available, I included a section of the entry subtitled "Music," within which I identified the publishing genre ("sheet music," "song collection"), the length of the musical portion of the published score in printed pages, information about vocal range or instrumentation, the initial key signature and tempo notations, and copyright or plate numbers. Since key signature and tempo notations do not offer much insight into the overall character of a piece of music, their inclusion might at first seem odd. However, I provided key signature information because settings are sometimes published in more than one key, listing the numbers of sharps or flats rather than the more common designation (for example B-flat minor) to aid users not adept at reading music. While tempo notations do offer some indication of the tone of a work, I included them for the same reason: to help users of the bibliography discover whether their copy varied from the one described in the entry. ${ }^{40}$

D. Title Page and Cover Transcriptions: Entries including sheet music and other separately published items should also provide title-page transcriptions. For sheet music, this means transcribing the cover: some can be represented in quasi-facsimile, but complex graphic designs resist transcription. For a heavily illustrated cover, I included a brief description of its design and recorded specific textual information such as dedications, song title, names (author and composer), price, publishing information, and publisher's numbers. The number of settings in my work made it impossible to present photographs of more than a few items; at the other extreme, J. Howard Woolmer's bibliography of Malcolm Lowry includes only two settings (in a section titled "Song Lyrics"), which allowed him to provide a photograph of the sheet music cover for both entries. ${ }^{41}$

E. Composition, Performance, and other Notes: Any information about the composition, printing, and publication of a musical setting, whether from the author's or composer's perspective, will be of interest to readers. If published secondary sources (such as correspondence or interviews) provide insight into the composition or production process, it is easy enough to include a summary note with citation sources. But when composition and production details derive from unpublished sources to which most readers will not have access, a longer discussion may be war-

40. For an example of a bibliography that provides more detail about musical scores, see East, Browning Music.

41. Woolmer, Malcom Lowry, 162-63. 
ranted. In any case, archival sources should be identified in enough detail for readers to track them down.

The reception of musical settings can be determined from public and private performances, reviews of performances, and reviews of the published score itself, as well as references in other contemporary documents, published and unpublished. Reviews of the score are particularly useful, especially in conjunction with advertisements, to help confirm publication dates. Performances, and especially reviews of performances, offer valuable information about a work's reception by contemporary audiences. If lists of reviews or performances are so lengthy as to be unwieldy, the bibliographer might adopt a policy of only recording the first few, or those appearing in important venues.

For post-1900 settings, sound recordings begin to take the place of live performances in determining reception, and they certainly reach a wider audience. If a variety of sound recordings exist - for example, readings of the author's work, interviews, or other audio-transcriptions - the bibliographer will have to decide whether to list all recordings together or to list recordings of musical settings in the music section. On the one hand, when all sound recordings are grouped together, it is easier to devise a uniform format for entries and treat each in some detail, so that cover art, LP or CD liner notes, reviews, and other information can be provided. On the other hand, by placing musical recordings in the music section, as in a note to an entry for a score, the bibliographer might condense the information about the recordings to prevent the entry from becoming unwieldy.

\section{Rationale}

A. Introduction and Headnotes: The ultimate value of an author bibliography rests not only on its content but also on the thought processes that went in to discovering, analyzing, and displaying it. Bibliographical lists represent the bibliographer's choices. Since those choices are rarely, if ever, explained adequately by the lists themselves, authors of bibliographies should provide a rationale for the bibliography's contents and methods in an introduction. In some respects, the introduction to a bibliography can be its most important feature, allowing readers to contextualize its contents and enabling scholars who are not bibliographers themselves to better grasp what bibliographical scholarship contributes to their work. If musical settings are included in a bibliography, the ra- 
tionale for their inclusion should be discussed in some detail, regardless of the number of settings, since one might argue that a short section is harder to justify than a longer one that, by length alone, indicates why musical settings played an important part in the author's overall publishing history. A sentence or two acknowledging the presence of musical settings, unaccompanied by any substantive discussion, implies that this category of publication is of little significance - and if that is the case, why include it at all? But assuming that a serious bibliographer has struggled, at least to some degree, with the various issues raised by musical settings, that bibliographer must also have drawn unique and valuable conclusions about the role of music in the author's printing and reception history, and consequently about the ways this information shaped the construction of the bibliography's music section. If those conclusions are not incorporated into the work, this important aspect remains invisible, depriving the bibliography's readers of the bibliographer's hard-won insight. 


\section{Musical Settings in Author Bibliographies}

\section{APPENDIX}

Selected Reference Sources for Music Bibliography

Note: All quotations are taken from the cited source.

$$
\text { 1. General Research and Reference Tools for Music }
$$

Baker, Theodore. Baker's Biographical Dictionary of Musicians. Ed. Nicolas Slonimsky and Laura Diane Kuhn. 9th ed. 6 vols. New York: Schirmer Books, 2001. Note: Available online from Gale Cengage.

Crabtree, Phillip D., and Donald H. Foster. Sourcebook for Research in Music. and ed. Revised and expanded by Allen Scott. Bloomington and Indianapolis: Indiana University Press, 2005.

Drone, Jeanette Marie. Musical AKAs: Assumed Names and Sobriquets of Composers, Songwriters, Librettists, Lyricists, Hymnists, and Writers on Music. Lanham, MD: Scarecrow Press, 2007.

Sadie, Stanley, and John Tyrrell, eds. The New Grove Dictionary of Music and Musicians. 29 vols. New York: Grove, 2001. Note: Grove Music Online, available from Oxford University Press, combines this with several other music reference texts.

\section{Bibliographies and Other Scholarship on Musical Settings}

\section{A: Broad Coverage}

Bradley, Carol June. Index to Poetry in Music. London: Routledge, 2003.

Carman, Judith E., William K. Gaeddert, and Rita M. Resch. Art Song in the United States, 1759-2011. Lanham, MD: Scarecrow Press, 2013.

Dictionary of North American Hymnology. The Hymn Society of the United States and Canada. http://www.hymnary.org/dnah.

Ezust, Emily. Lied, Art Song, and Choral Text Archive. http://www.recmusic.org/lieder/.

Ferguson, Gary Lynn. Song Finder: A Title Index to 32, ooo Popular Songs in Collections, 1854-1992. Westport, CT: Greenwood, 1995.

Gooch, Bryan N. S., and David S. Thatcher. Musical Settings of British Romantic Literature: A Catalogue. 2 vols. Garland Reference Library of the Humanities, 326. New York: Garland, 1982.

-Musical Settings of Early and Mid-Victorian Literature: A Catalogue. Garland Reference Library of the Humanities, 149. New York: Garland, 1979.

- Musical Settings of Late Victorian and Modern British Literature: A Catalogue. Garland Reference Library of the Humanities, 31. New York: Garland, 1976.

Hovland, Michael A. Musical Settings of American Poetry: A Bibliography. Music Reference Collection 8. Westport, CT: Greenwood Press, 1986.

HymnQuest. The Rev. Brian Hoare, the Rev. Don Pickard, eds. Stainer and Bell. http:// hymnquest.com. 
Kramer, Lawrence. Music and Poetry: The Nineteenth Century and After. Berkeley, CA: University of California Press, 1984.

Julian, John D. A Dictionary of Hymnology. 1892. Reprint New York: Dover, 1957; Grand Rapids, MI: Kregel, 1985.

\section{B: Musical Settings of Specific Authors}

Bloomfield, B. C., and Edward Mendelson. W. H. Auden: A Bibliography 1924-1969. 2nd ed. Charlottesville, VA: University of Virginia Press, 1972.

Crandell, George W. Ogden Nash: A Descriptive Bibliography. Pittsburgh, PA: University of Pittsburgh Press, 1995.

- Tennessee Williams: A Descriptive Bibliography. Pittsburgh, PA: University of Pittsburgh Press, 1995.

East, Sally Keith Carroll. Browning Music: A Descriptive Catalog of the Music Related to Robert Browning and Elizabeth Barrett Browning in the Armstrong Browning Library. Waco, TX: Armstrong Browning Library, 1972.

Firmage, George J. E. E. Cummings: A Bibliography. Westport, CT: Greenwood Press, 1960 .

Fitch, Donald. Blake Set to Music: A Bibliography of Musical Settings of the Poems and Prose of William Blake. Berkeley, CA: University of California Press, 1990.

George, Roderick. An Annotated Bibliography of Song Settings for Solo Voice and Piano by American Composers of the Poetry of Paul Laurence Dunbar and Langston Hughes. PhD diss., Florida State University, 2000.

Gooch, Bryan N., and David Thatcher, David. A Shakespeare Music Catalogue. 5 vols. Incorporating material collected and contributed by Charles Haywood. Oxford: Clarendon Press, 1991.

Hagstrom, Jack W. C., and Bill Morgan. James Ingram Merrill: A Descriptive Bibliography. New Castle, DE: Oak Knoll Press, 2009.

Kramer, Lawrence, ed. Walt Whitman and Modern Music: War, Desire, and the Trials of Nationhood. New York: Garland, 200o. Note: Includes a CD.

Lowenberg, Carlton. Musicians Wrestle Everywhere: Emily Dickinson and Music. Fallen Leaf Reference Books in Music 19. Berkeley, CA: Fallen Leaf Press, 1992.

Neilson, Kenneth P. The World of Langston Hughes Music. Hollis, NY: All Seasons Art, 1982.

Pollin, Burton Ralph. Music for Shelley's Poetry: an Annotated Bibliography of Musical Settings of Shelley's Poetry. New York: Da Capo Press, 1974.

Rugoff, Kathy. "Opera and Other Kinds of Music." In A Companion to Walt Whitman, ed. Donald D. Kummings, 237-71. Blackwell Companions to Literature and Culture 40. Malden, MA: Blackwell Publishing, 2006.

Woolmer, J. Howard. Malcolm Lowry: A Bibliography. Revere, PA: Woolmer/Brotherson, 1983 . 


\section{Musical Settings in Author Bibliographies}

\section{Sources in Music Publishing History and Bibliography}

Gamble, William. Music Engraving and Printing: Historical and Technical Treatise. 1923. Da Capo Press Music Reprint Series. New York: Da Capo Press, 1971.

Green, Richard D., ed. Foundations in Music Bibliography. New York: Haywood Press, 1993.

Humphries, Charles, and William C. Smith. Music Publishing in the British Isles from the Beginning until the Middle of the Nineteenth Century. 2nd ed., with supplement. Oxford: Basil Blackwell, 1970.

Hunter, David, Ann Basart, Harold Diamond, Jane Gottlieb, and David Lasocki. "Music Library Association Guidelines for the Preparation of Music Reference Works." Notes: Quarterly Journal of the Music Library Association 50, no. 4 (1994): 1329-38.

Krummel, Donald W. "Varieties and Uses of Music Bibliography." In Foundations in Music Bibliography, ed. Richard D. Green, 1-26. New York: Haywood Press, 1993.

The Literature of Music Bibliography: An Account of the Writings on the History of Music Printing and Publishing. Fallen Leaf Reference Books in Music, 21. Berkeley, CA: Fallen Leaf Press, 1992.

and Stanley Sadie, eds. Music Printing and Publishing. The Norton/Grove Handbooks in Music. New York: W. W. Norton, 1990.

LaRue, Jan, and David Cannata. "An Ancient Crisis in Music Bibliography: The Need for Incipits." Notes: Quarterly Journal of the Music Library Association 50, no. 2 (1993): 502-518.

Scott, Derek B. Sounds of the Metropolis: The 19th-Century Popular Music Revolution in London, New York, Paris, and Vienna. New York: Oxford University Press, 2008.

van Orden, Kate, ed. Music and the Cultures of Print. New York: Garland, 2000.

\section{Indexes to Songs in Collections}

Arizona State University Music Library. ASU Song Index. http://spmi.lib.asu.edu/ songs. Note: According to information provided elsewhere on the library's web pages (http://libguides.asu.edu/content.php?pid=16129), the Index "contains popular, folk, and art songs found in collections of songs owned by the Music Library"; entries include "the title of the song, the composer, lyricist, first line, and the collection in which it is found."

California Library Systems Cooperative Song Index. http://www.sjvls.org/songs/index. html. Note: Searchable by title only; "contains more than 180,000 song titles (mostly popular music) from over 2,000 sheet music collections."

DeCharms, Desiree, and Paul F. Breed. Songs in Collections: An Index. Detroit, MI: Information Services, 1966.

Goleeke, Tom. Literature for Voice: An Index of Songs in Collections and Source Book for Teachers of Singing. Metuchen, NJ: Scarecrow Press, 1984.

. Literature for Voice, Volume II: An Index to Songs in Collections, 1985-200o. Lanham, MD: Scarecrow Press, 2002. 
Havlice, Patricia Pate. Popular Song Index. Metuchen, NJ: Scarecrow Press, 1975.

. Popular Song Index: First Supplement. Metuchen, NJ: Scarecrow Press, 1978.

- Popular Song Index: Second Supplement. Metuchen, NJ: Scarecrow Press, 1984.

- Popular Song Index: Third Supplement. Metuchen, NJ: Scarecrow Press, 1989.

The Index to Printed Music: Collections and Series. EBCSO. http://www.ebscohost.com.

Leigh, Robert. Index to Song Books; A Title Index to Over 11, ooo Copies of Almost 6,800 Songs in 111 Song Books Published Between 1933 and 1962. 1964. Reprint, New York: Da Capo Press, 1973. Note: Searchable by title only.

Luchinsky, Ellen. The Song Index of the Enoch Pratt Free Library. 2 vols. New York: Garland, 1998. Note: Searchable only by composer, title, and source (larger works, film or television show title, etc.).

Oberlin College Conservatory Library. Oberlin Song Index. http://www.oberlin.edu/ cgi-in/cgiwrap/library/ref/index.php?db=songindex. Note: "Index of 52,000+ songs in anthologies held by the Oberlin Conservatory Library."

Pressler Music Library, West Chester University of Pennsylvania. Index to Art Songs and Arias in Anthologies. http://subjectguides.wcupa.edu/content.php?pid=20836.

Sears, Minnie Earl. Song Index; An Index to More than 12, ooo Songs in 177 Song Collections Comprising 262 Volumes. New York: H. W. Wilson Company, 1926. Note: Searchable by author, composer and title.

University of Tennessee Libraries. UT Song Index. http://www.lib.utk.edu/databases/ songdb/. Note: Includes "about 50,000 songs in more than 1,500 published song anthologies owned by the George F. DeVine Music Library at the University of Tennessee."

\section{Tools for Locating Collections of Musical Settings, Including Digital Collections}

African American Music Reference. Alexander Street Press. http://alexanderstreet.com/ products/african-american-music-reference.

Anderson, Margaret Vail. “Locating Lyrics, Sheet Music, Librettos \& Scores.” Digital Librarian. http://www.digital-librarian.com/sheet.html. Note: An extensive list of libraries, archives, digital collections, and other resources.

Day, David. "Digital Collections.” MusRef. Brigham Young University. http://lib.byu. edu/sites/musref/about/

Harvard College Library. Harvard Online Resources for Music Scholars. http://hcl.harvard.edu/research/guides/onmusic/. Note: Includes "links to archival collections, online scores and sound recordings; article indexes, discographies and bibliographies; scholarly societies; musical reference works; and a miscellany of useful websites," with brief annotations.

International Music Score Library Project (IMSLP). Petrucci Music Library. http://imslp. org/wiki/Main_Page. Note: Provides digitized public domain scores, and the "Other music score websites" section lists major library collections in several countries.

Music Library, Duke University. Sheet Music Collections. http://library.duke.edu/music/ sheetmusic/collections.html. Note: Coverage is primarily (but not exclusively) United States. 


\section{Musical Settings in Author Bibliographies}

United Kingdom \& Ireland Branch of the International Association of Music Libraries, Archives and Documentation Centres. CECELIA. http://www.cecilia-uk.org/. Note: "[A]n on-line guide to music collections in archives, libraries and museums in the UK and Ireland."

\section{Significant Library Collections, Including Digital Archives.}

Note: This is a selective list of major collections, with emphasis on art song, popular sheet music and other collections likely to hold musical settings.

\section{A: United Kingdom}

British Library. "Help for Researchers." http://www.bl.uk/reshelp/bldept/music/. Note: This is the starting point for searching the library's extensive holdings.

Bodleian Library. Note: Most, but not all, printed music has been entered in the online catalogue, but see the guide to "Searching for Printed Music Scores and Recordings on OLIS," http://www.bodleian.ox.ac.uk/_data/assets/pdf_file/oorg/25282/musicsearching.pdf, and other information on the "Finding Aids-Music Collections" section of the library's website, http://libguides.bodleian.ox.ac.uk/music-sc.

National Library of Scotland. http://www.nls.uk/collections/music. Note: "The music collections now include extensive British holdings, especially Scottish music."

Royal Academy of Music Library. http://www.ram.ac.uk/library Note: "The Library has over 200,000 items."

Royal College of Music Library. http://www.rcm.ac.uk/library/. Note: "[O]ver 500,000 items."

\section{B: United States}

American Antiquarian Society. Sheet Music Collection. http://www.americanantiquarian.org/sheetmusic.htm. Note: "[A]bout 6o, ooo pieces of instrumental, vocal, secular, and religious music by both American and foreign composers that were printed through 1880."

Baylor University. Frances G. Spencer Collection of American Popular Sheet Music. http:// digitalcollections.baylor.edu/cdm/history/collection/fa-spnc. Note: "[A]pproximately 30,000 pieces of music published between the late 1700 and mid-190os."

Brown University, John Hay Library. Sheet Music Collection. Note: Of special interest is the Brown University Library Center for Digital Scholarship's African-American Sheet Music, 1850-1920 digital project at http://library.brown.edu/cds/sheetmusic/ afam/index.html. "This consists of music by and relating to African Americans, from the 1820 s to the present day, and consists of approximately 6,00o items. Of that number, 1,700 items are fully cataloged in MARC format, from which the titles digitized in this project have been drawn." The full Sheet Music Collection at the John Hay Library at Brown University "consists of approximately 500,000 items."

Boston Public Library, Music Department. http://www.bpl.org/research/music/aboutmusic.htm. Note: Not all materials are catalogued; contacting or visiting the library is recommended. See also "Use of the Music Department Collections" at http://www. bpl.org/research/music/spmusic.htm\#use_music. 
Duke University, David M. Rubenstein Rare Book and Manuscript Library. Historic American Sheet Music 1850-1920. http://library.duke.edu/digitalcollections/hasm/. Note: "The Historic American Sheet Music Project provides access to digital images of 3042 pieces from the collection, published in the United States between 1850 and 1920."

Fayetteville Free Library. Motto Sheet Music Collection. http://fflib.org/motto. Note: "[T]housands of pieces of popular American sheet music and hundreds of music books" from the Civil War through the 1980s.

Indiana University, Bloomington, Lilly Library. Sheet Music Collections. http://www. indiana.edu/ liblilly/collections/sheetmusic.shtml. Note: See also the digital archive IN Harmony: Sheet Music from Indiana, at http://webappı.dlib.indiana.edu/inharmony/welcome.do.

Johns Hopkins University. Lester S. Levy Sheet Music Collection. http://levysheetmusic. mse.jhu.edu/about. Note: "[O]ver 29,000 pieces of American popular music," from 1780 through 1980 .

Library of Congress, Music Division. http://www.loc.gov/rr/perform/div-intro.html. Note: Full access to the music collection, including copyright records, is only available onsite. The digital archive Music for the Nation, comprising two collections (18201860 and $1870-1885$ ) is an important resource for nineteenth-century musical settings. http://memory.loc.gov/ammem/mussmhtml/mussmhome.html.

Middle Tennessee State University, Center for Popular Music. http://popmusic.mtsu. edu/ Note: "Collections of music include Sheet Music, Song Broadsides, Rare Books and Scores, and Sound Recordings."

Mississippi State University, Mitchell Memorial Library. Charles Templeton Sheet Music Collection. http://digital.library.msstate.edu/cdm/landingpage/collection/SheetMusic.

New York Public Library, Music Division. http://www.nypl.org/locations/lpa/musicdivision. Note: Extensive holdings of American sheet music, including more than 400,000 titles from the estate of George Goodwin; "over 100,000 of our scores do not appear in the online Catalog." See also http://digitalgallery.nypl.org/nypldigital/ explore/dgexplore.cfm?col_id=148.

Northwestern University Library, Music Library. http://www.library.northwestern.edu/ libraries-collections/evanston-campus/music26. Note: Especially strong in twentieth century music.

University of North Texas Libraries, Music Special Collections Catalog. http://iii.library.unt.edu:81/. Note: Database of popular music titles from several of the library's collections; "includes an index of songs published in Sheet Music Magazine and Piano Today."

San Francisco Public Library. Dorothy Starr Sheet Music Collection. http://sflibi.sfpl. org:84/. Note: The Dorothy Starr collection includes "over 300,000 pieces of music for choir and ensemble, opera scores, children's music, popular, folk and art songs," over 10,000 of which can be browsed via the Collection's database.

University of California, Berkeley. 19th-Century California Sheet Music. Managed by Mary Kay Duggan. http://people.ischool.berkeley.edu/ mkduggan/neh.html. Note: "2,700 pieces of sheet music published in California between $185^{2}$ and 1900, [. . ] with related materials.” 


\section{Musical Settings in Author Bibliographies}

University of California, Los Angeles. Archive of Popular American Music. http://digital.library.ucla.edu/apam/. "[A] research collection covering the history of popular music in the United States from 1790 to the present [...] numbering almost 450,000 pieces of sheet music, anthologies, and arrangements for band and orchestra."

. Sheet Music Consortium: Sheet Music on the Web. http://digital2.library.ucla.edu/ sheetmusic/. Note: A total of 226,914 items drawn from sixteen library collections (with additional collections being added).

University of Colorado at Boulder, Music Library, Digital Sheet Music Collection. http:// ucblibraries.colorado.edu/music/smp/. Note: The library's entire holdings comprise "approximately 150,000 items including examples from the late 18th through the 2oth centuries."

University of Illinois at Urbana-Champaign. U. S. Sheet Music Collection. http://www. library.illinois.edu/mux/about/collections/specialcollections/uiucsheetmusic.html. Note: "[A]bout 100,000 titles of popular music from the early 19th century through the 1980 ."

University of Oregon Libraries. Music Collection. http://library.uoregon.edu/music/index.html. Note: The University's collection includes over 30,000 music scores and parts, including the digital Historic Sheet Music Collection at http://oregondigital.org/ digcol/sheetmusic/, which incorporates titles from the Oregon Music Collection and the Women Composers Collection. The library also maintains an Online Sheet Music In$\operatorname{dex}$ (http://library.uoregon.edu/tools/sheetmusic/) which represents approximately half of the collection.

University of North Carolina, Chapel Hill, Music Library. 19th Century American Sheet Music. http://www.lib.unc.edu/dc/sheetmusic/. Note: "[A]pproximately 3,500 popular vocal and instrumental titles from the 1830 s to the end of the century."

University of Pennsylvania. Keffer Collection of Sheet Music. http://www.library.upenn. $\mathrm{edu} /$ collections/rbm/keffer/. Note: "2,531 scores ranging in date from ca. 1790 to 1895 ."

University of Rochester, Sibley Music Library. Musical Scores. https://urresearch.rochester.edu/viewInstitutionalCollection.action?collectionId=63. Note: "Scores and books in the public domain. Many of these are unique to the Sibley Music Library collection."

University of South Florida. NationsBank African-American Musical Heritage Collection. http://beta.worldcat.org/archivegrid/collection/data/50638318. Note: "[O]ver 4,ooo pieces of sheet music documenting the contributions of African-Americans to the nation's musical heritage."

Yale University, Beinecke Rare Book \& Manuscript Library. http://beinecke.library.yale. edu/collections/curatorial-areas/music-beinecke. Note: A number of musical settings are included in the Yale Collection of American Literature, and especially within the James Weldon Johnson Memorial Collection. 

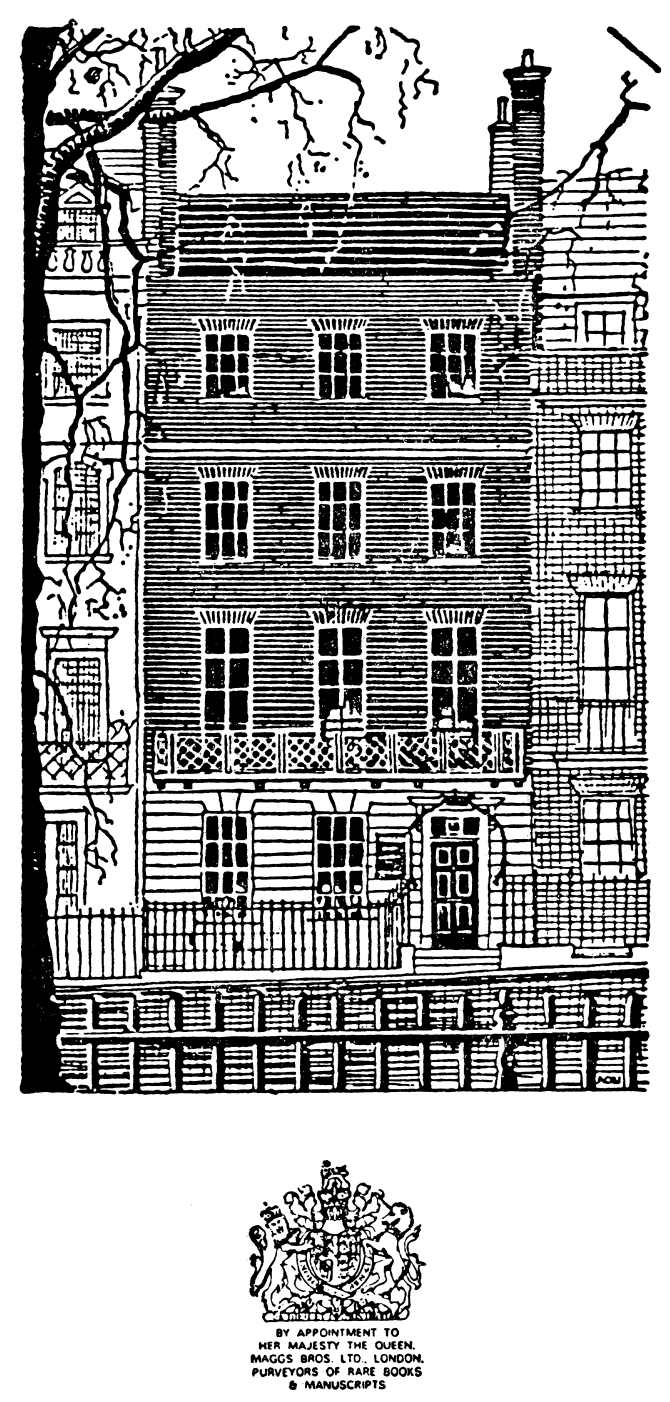

\section{MAGGS BROS. Ltd.}

\section{Berkeley Square London $\mathrm{W}_{1}{ }_{5} \mathrm{BA}$}

EMAIL: ed@maggs.com

WEB: WWW.maggs.com
TEL: O2O 74937 I6O

FAX: 02074992007 


\title{
Caxton's Editing of the Canterbury Tales
}

\author{
Barbara Bordalejo
}

$\mathrm{I}^{\mathrm{N}}$ N THE PREFAce to his second edition of the Canterbury Tales, William Caxton made what has become a well-known statement. ${ }^{1} \mathrm{He}$ declared that a gentleman had told him that his first edition of the Tales was inaccurate and that he could provide a better manuscript, one truer to Chaucer's text. Caxton claimed that he corrected the book based on the manuscript with which he had been provided and printed a second edition:

1. Caxton's first edition of the Canterbury Tales ( $\mathrm{STC}_{5082}$, referred to in this article as $\mathrm{Cx}^{1}$ ) has been dated to either 1476 or 1477 . Lotte Hellinga thinks the likely date is the earlier one (Caxton in Focus: The Beginning of Printing in England [London: British Library, 1982], 67-8, 80-1), but Paul Needham dates it 1477 (The Printer E the Pardoner [Washington, DC: Library of the Congress, 1986], 84), following Norman Francis Blake (Caxton: England's First Publisher [London: Deutsch, 1976], 127-8), who later changed his opinion and stated that the date for $\mathrm{Cx}^{1}$ was "almost certainly" 1476 (The Textual Tradition of the Canterbury Tales [London and Baltimore: Edward Arnold, 1985], 1). The second edition (STC 5088, referred to in this article as $\mathrm{Cx}^{2}$ ), has been dated to either 1482 or 1483 . However the dating of $\mathrm{Cx}^{2}$ depends on that of $\mathrm{Cx}^{1}$, since the book's second edition was, Caxton declares, printed six years after $\mathrm{Cx}^{1}$. Thus Needham dates $\mathrm{Cx}^{2}$ as 1483 (The Printer, 87), while Hellinga's dating of $\mathrm{Cx}^{1}$ as 1476 would bring the date of $\mathrm{Cx}^{2}$ to 1482, a date also accepted by Blake (England's, 5).

Barbara Bordalejo (Department of Modern Languages, University of Birmingham, Edgbaston, Birmingham, UK, $\mathrm{B}_{15} 2 \mathrm{TT}$ ) is a digital humanist and a textual scholar with a background in English Literature. She has published editions of Chaucer's Canterbury Tales (http://caxton.dmu.ac.uk/) and Darwin's Origin of Species (http://darwin-online. org.uk/Variorum/). Her interests include digital literature and transmedia storytelling, as well as the transformational impact of digital culture on our ideas of authorship and copyright. She advocates data sharing through creative commons licences without commercial restrictions. Barbara teaches digital literature, new media, and English literature and is a member of the executive of Global Outlook :: Digital Humanities. She is a Senior Research Fellow at the University of Birmingham and can be contacted at b.bordalejo@bham.ac.uk. 
For I fynde many of the sayd bookes, whyche wryters haue abrydgyd it and many thynges left out, And in somme place haue sette certayn versys, that he neuer made ne sette in his booke, of whyche bookes so incorrecte was one brought to me vj yere passyd, whyche I supposed had ben veray true \& correcte, And accordyng to the same I dyde do enprynte a certayn nombre of them, whyche anon were sold to many and dyuerse gentyl men, of whome one gentylman cam to me, and said that this book was not accordyng in many places vnto the book that Gefferey chaucer had made, To whom I answerd that I had made it accordyng to my copye, and by me was nothyng added ne mynusshyd, Thenne he sayd he knewe a book whyche hys fader had and moche louyd, that was very trewe, and accordyng vnto hys owen first book by hym made, and sayd more yf I wold enprynte it agayn he wold gete me the same book for a copye, how be it he wyst wel, that hys fader wold not gladly departe fro it, To whom I said, in caas that he coude gete me suche a book trewe and correcte, yet I wold ones endeuoyre me to enprynte it again, for to satysfye thauctour, where as to fore by ygnoraunce I erryd in hurtyng and dyffamyng his book in dyuerce places in setting in somme thynges that he neuer sayd ne made, and leuyng out many thynges that he made whyche ben requysite to be sette in it, And thus we fyll at accord, And he ful gentylly gate of hys fader the said book, and delyuerd it to me, by which I haue corrected my book. ${ }^{2}$

This article shows that Caxton was accurate in his statement about the corrections introduced in his second edition of the Tales, and that he and his compositors were generally far more careful than some modern scholars have acknowledged. Using textual evidence drawn from a direct comparison of the two editions, I demonstrate: that Caxton did more than add and remove lines; that besides those changes, he introduced more than 3,000 alterations that originated in a different manuscript source; and that this manuscript source contained a text closer to the archetype of the tradition (see Appendix A). This evidence is drawn from my own textual research on William Caxton's editions of the Tales, for which completely new collations were carried out.

\section{COMPUTER-AIDED COLLATION OF THE CAXTON EDITIONS}

As part of my $\mathrm{PhD}$ at De Montfort University, I made complete electronic transcriptions of both of Caxton's editions of the Canterbury Tales. ${ }^{3}$ In order to establish the differences between the transcripts, I

2. $\mathrm{Cx}^{2}, \mathrm{a} 2^{\mathrm{r}-\mathrm{v}}$.

3. Barbara Bordalejo, "Caxton's Second Edition of the Canterbury Tales and its Place in the Textual Tradition of the Tales" (PhD diss., De Montfort University, 2003). The transcriptions were published electronically in Barbara Bordalejo, ed., Caxton's "Canterbury Tales": The British Library Copies (Leicester: Scholarly Digital Editions, 2003), CD-ROM, and can also be found freely available online at http:// caxton.dmu.ac.uk/. 


\section{Caxton's Editing of the "Canterbury Tales"}

used Collate, a program developed in the early 1990 for the collation of large textual traditions. Collate in its default mode shows every difference between transcripts, and makes no distinction between variants that might be significant for the establishment of textual relationships (stemmatically significant variants) and those that are not. Any differences in spelling, in word division, or in the encoding, such as the size of an ornamental capital, are also understood as variation. A typical result of a collation carried out with the help of Collate is, for the first line of the "Miller's Tale":

[2orncp]W[/2orncp]Hilom ] [4xcp]W[/4xcp]Hylom $\mathrm{Cx}^{2}$

therwas ] ther was $\mathrm{Cx}^{2}$

dwelling\&tail; ] dwellyng $\mathrm{Cx}^{2}$

In this example, all differences between Caxton's first edition of the Tales, here used as a base for collation, and his second edition are shown. The first word, "Whilom," which presents two different spellings and encodings, appears as a variant. The next item, "therwas" appears as a single word in $\mathrm{Cx}^{1}$ and as two words in $\mathrm{Cx}^{2}$. The only difference in the word "dwelling" is the tail in the final $g$ in $\mathrm{Cx}^{1}$. In fact, none of these variants in this first line of the "Miller's Tale" are stemmatically significant. ${ }^{4}$ "Stemmatically significant" variants are those that are useful for the establishment of genetic links between different texts. Variations such as those in spelling, encoding, or word division as seen in this first line of the tale are likely to reflect only differences in practice between the compositors of the two editions.

The whole collation had to be read through in order to filter out all instances of variation that were not stemmatically significant. For example, the second line of the "Miller's Tale" contains the following variant: chuf] gnof $\mathrm{Cx}^{2}$

Here, the change from "chuf" to "gnof" is potentially stemmatically significant. I use the word "potentially" because it is not possible to decide just by looking at the collation of these two witnesses whether these variants contain information about the affiliations of the source manuscripts. There are three possible ways the variant in $\mathrm{Cx}^{2}$ could appear: it could be the result of a correction based on a different text; it could be a compositorial error; or it could be Caxton's own invention and likely to

4. Complete collations of the "Miller's Tale" can be found in Peter M. W. Robinson, ed., The Miller's Tale on CD-ROM (Leicester: Scholarly Digital Editions, 2004), CD-ROM. 
be found nowhere else in the tradition. The more variants we find of the first type, the more likely it is that Caxton did as he said and introduced readings from another manuscript. ${ }^{5}$ Thus, one has to examine the distribution of these variants in the whole tradition for evidence that might support or deny Caxton's assertion that he used a manuscript nearer to the archetype in preparing his second edition. If Caxton's account is to be trusted, we would expect that the reading "gnof" was present in the manuscript given to him by the unnamed gentleman. If we discover that this reading and many others like it are also the readings of manuscripts that are considered to have been close to the archetype of the whole tradition, then we have evidence that Caxton did indeed introduce readings from a manuscript close to the archetype into his second edition.

\section{SAMPLE SECTION: “THE SQUIRE'S TALE”}

Ideally, one would present the complete table of variants between $\mathrm{Cx}^{1}$ and $\mathrm{Cx}^{2}$ for evaluation by the reader. However, the amount of data is large, especially if every one of the steps described above is to be followed. Instead of attempting to deal with the complete dataset, ${ }^{6} \mathrm{I}$ focus on a single tale. ${ }^{7}$

Appendix A lists all 132 significant variants between $\mathrm{Cx}^{1}$ and $\mathrm{Cx}^{2}$ in the 664 lines of the "Squire's Tale." I give also the occurrence of the $\mathrm{Cx}^{2}$ variants in ten manuscript copies, transcripts of which were made available to me for collation by the Canterbury Tales Project. ${ }^{8}$ Of those 132 ,

5. My research on the manuscript source used by Caxton to correct his first edition required a further set of collations that included other witnesses. The second set of collations was designed to show whether the readings introduced in $\mathrm{Cx}^{2}$ could have been drawn from another witness (as opposed to emendations invented by Caxton himself or those that were the result of chance or accident) and whether it was possible to establish the affiliations of their manuscript source. The list of consulted witnesses and their sigils is in Appendix $\mathrm{C}$ to this article.

6. See Bordalejo, "Caxton's Second Edition," 117ff, for a full list of the variants in the Canterbury Tales.

7. I chose the "Squire's Tale" because this is one of the tales that Lotte Hellinga refers to as not having a large number of corrections (see below). The data is representative of the number of variants found in $\mathrm{Cx}^{2}$ and, up to a certain point, it shows the patterns of variant distribution within the textual tradition.

8. For the "Squire's Tale," I collated $\mathrm{Cx}^{1}, \mathrm{Cx}^{2}$ along with $\mathrm{Hg}, \mathrm{El}, \mathrm{Ad}_{3}, \mathrm{Bo} 2, \mathrm{Ch}$, $\mathrm{Cp}, \mathrm{Dd}, \mathrm{Gg}, \mathrm{Ha} 4$, and La. 


\section{Caxton's Editing of the "Canterbury Tales"}

twelve are unique. $^{9}$ If we discard the twelve unique variants, likely to be compositorial errors, we are left with 120 variants. This represents a significant change every five lines if we count all 132 places of variation, or one every five and one-half lines if we consider 120 . Generally we can talk about roughly one significant change every five lines.

\section{THE SOURCE OF THE VARIANTS}

The sample variants from the "Squire's Tale" show that Caxton did do the first part of what he claimed: he introduced a large number of readings into the text of $\mathrm{Cx}^{2}$. We can also assess the veracity of the second part of his statement: that he adopted these readings from a text closer to the archetype of the tradition than was $\mathrm{Cx}^{1}$.

The result of generations of textual scholarship on the Tales is a broad consensus about which of the extant manuscripts are likely to be closest to the lost archetype of the whole tradition. Key here is the work of John Manly and Edith Rickert, ${ }^{10}$ who built on research by Tatlock and other scholars, and who identified the Hengwrt $(\mathrm{Hg})$ and Ellesmere (El) manuscripts as nearest to their "O," the origin of the whole tradition. Recently, the Canterbury Tales Project has elaborated on this work, demonstrating that a small set of other manuscripts represent independent lines of descent from the archetype, from which they are separated by relatively few intervening copies, and so are likely to preserve archetypal readings. The project labeled these the "O" manuscripts, and for the sections so far analyzed by the project, identified them as $\mathrm{Ch}, \mathrm{Gg}$, $\mathrm{Ha}_{4}$, and $\mathrm{Ad}_{3}$, together with $\mathrm{El}$ and $\mathrm{Hg} .{ }^{11}$ Of these, Ch consistently is closest to $\mathrm{El}$ and $\mathrm{Hg}$, effectively forming an "inner three" group.

It lies outside the scope of this article to determine the exact place of the source manuscript used by Caxton relative to the other manuscripts of the Tales and hence to the archetype. It is sufficient for my argument

9. Variants that are present in only one witness are non-classificatory from a stemmatic perspective. However, the unique variants in this collation are only unique in the sense that they are not shared by any other collated witness. Once all the transcriptions of the "Squire's Tale" become available, it might be that some variants I refer here to as unique are discovered to be present in other witnesses.

10. John M. Manly and Edith Rickert, eds., The Text of the Canterbury Tales: Studied on the Basis of All Known Manuscripts, 8 vols. (Chicago: Chicago University Press, 1940).

11. Here I present a simplified version of the textual tradition. The individual publications of the project contain fuller information referring to particular sections of the text. 
that again and again, the reading introduced into $\mathrm{Cx}^{2}$ is also found in the "O" manuscripts, particularly in $\mathrm{Hg}, \mathrm{El}$, and $\mathrm{Ch}$, and for this reason it is likely to have been the archetypal reading. Of the 120 readings introduced in $\mathrm{Cx}^{2}$ and shared with other witnesses, 100 appear in the "inner three" of $\mathrm{Hg}, \mathrm{El}$, and $\mathrm{Ch}$. In contrast, the $\mathrm{Cx}^{1}$ reading replaced in $\mathrm{Cx}^{2}$ is very often the reading of the small group of manuscripts labeled as "b" by Manly and Rickert: essentially, He, Ne, and Tc2. This group is characterized by many readings introduced below the archetype, with their number and nature suggesting a long line of intervening copies between the archetype and the " $b$ " manuscripts. Thus, we find over and over-in around a hundred cases in the "Squire's Tale," in thousands of instances across the whole Tales - that the $\mathrm{Cx}^{1}$ reading replaced by Caxton is found only in the " $\mathrm{b}$ " manuscripts, while the $\mathrm{Cx}^{2}$ reading replacing it is found in most (or even all) of the "O" manuscripts, and indeed in every other line of descent except "b."12 In the absence of an archetype, one might be hesitant about asserting that one reading is likely to be archetypal or another not, but in these instances, we may be confident that this is the case.

For example, in line 50 of "Squire's Tale," the reading "And so this kyng" is replaced in $\mathrm{Cx}^{2}$ by "Thys Cambuscan," which is in agreement with eight of the ten collated witnesses, including all of the "inner three." Something similar occurs in line 202, where "grekis" is substituted by "troye" in all ten collated witnesses. These variants are all stemmatically significant, and the vast majority of them appear to represent the replacement of a non-archetypal reading by an archetypal one. Moreover, many of the introduced changes significantly affect our reading of the text. An extraordinary instance is line 379 , where $\mathrm{Cx}^{2}$ reads "foure" in place of $\mathrm{Cx}^{1}$ "ten." The full line as it appears in $\mathrm{Cx}^{2}$ is:

That in the Ram is foure degrees up ronne

The reading "ten" is found widely in the tradition: in the " $b$ " group (whence it makes its way into $\mathrm{Cx}^{1}$ ), and in the very numerous "cd" group. "Foure," the reading accepted by all modern editors, is found in just five of the ten witnesses I collated, but that five includes the "inner three"

12. Thus, the $\mathrm{Cx}^{1}$ reading "chuf" in line 1 of the "Miller's Tale" discussed above appears also in the "b" manuscripts $\mathrm{Ne}$ and $\mathrm{Tc} 2$ (and in Ii, Se, and Ld2, apparently by coincidence), while "gnof" is in all six "O" manuscripts, as well as in Manly and Rickert's "a," "c," and "d" groups: a total of forty-three of the fifty-four witnesses and every line of descent except "b." 


\section{Caxton's Editing of the "Canterbury Tales"}

along with $\mathrm{Dd}$ and $\mathrm{Gg}$. Notable too are nine cases where the $\mathrm{Cx}^{2}$ reading agrees with $\mathrm{El}$ against $\mathrm{Hg}$, usually with a few other witnesses:

1. 15, "strong" $\mathrm{El}$ alone; "and strong" $\mathrm{Cx}^{1} \mathrm{Hg}$

1. 53, "feste so" $\mathrm{El} \mathrm{Ad} 3$ Dd Enl; "feste" $\mathrm{Cx}^{1} \mathrm{Hg}$

1. 194, "they demede" $\mathrm{El} \mathrm{Gg} \mathrm{Ha} 4 \mathrm{Ht}$; "demede" $\mathrm{Cx}^{1} \mathrm{Hg}$

1. 231, "wyth his" $\mathrm{El} \mathrm{Gg;} \mathrm{"for} \mathrm{his"} \mathrm{Cx}^{1} \mathrm{Hg}$

1. 290, "me" $\mathrm{El} \mathrm{Gg}$; "you" $\mathrm{Cx}^{1} \mathrm{Hg}$

1. 419, "and" $\mathrm{El} \mathrm{Gg;} \mathrm{"of"} \mathrm{Cx}^{1} \mathrm{Hg}$

1. 447, "loue" $\mathrm{El} \mathrm{Gg;} \mathrm{"Ire"} \mathrm{Cx}^{1} \mathrm{Hg}$

1. 491, "hard day" $\mathrm{El} \mathrm{Gg;"} \mathrm{"ilke} \mathrm{day"} \mathrm{Cx}^{1}$

1. 502, "that I ne coude" $\mathrm{El} \mathrm{Gg;} \mathrm{"that} \mathrm{no} \mathrm{wight} \mathrm{wolde"} \mathrm{CX}^{1}$

I observed above that 100 of the 120 non-unique $\mathrm{Cx}^{2}$ readings were found in $\mathrm{Hg}, \mathrm{El}$, and $\mathrm{Ch}$. Here, nine of the twenty not found in the "inner three" are found in $\mathrm{El}$, commonly with $\mathrm{Gg}$, an affiliation that can be observed elsewhere in the Tales. Thus, even where the manuscript source deviates from the "inner three," it commonly agrees with readings found in other manuscript combinations close to the archetype.

Another striking example in the "Squire's Tale," suggesting derivation from a manuscript close to the archetype, is the variant in line 289 (variant 63 in Appendix A), "haue that / soupen al by," in which the $\mathrm{Cx}^{2}$ reading, "supen al by," is supported by different lines of descent in the manuscript tradition. A similar conclusion can be reached from lines 631 "plastris / salues" (129 in Appendix A) or 277 "lokyngis / lokyng and dyssymylyngis" (6o in Appendix A). ${ }^{13}$

By examining the distribution of the variants in $\mathrm{Cx}^{1}$ and $\mathrm{Cx}^{2}$ across the whole textual tradition of the Tales, we find similar results in the texts of other verse tales. For example, line 65 of the "Miller's Tale" in $\mathrm{Cx}^{1}$ reads "Tarselid with grene," while $\mathrm{Cx}^{2}$ reads "sylk" instead of "grene." The variant "grene" here is restricted to the "b" group and El. In this case, not only has Caxton replaced the reading in $\mathrm{Cx}^{1}$ by a very different one in $\mathrm{Cx}^{2}$, but there is no doubt that he was following his source manuscript in this instance. It appears that the reading "sylk" was likely to have been present in the archetype of the whole tradition: hence its appearance in $\mathrm{Hg}$, and all of what we call the "O" manuscripts except El, representing an uncertain number of independent lines of descent, and in all other lines of descent except the "b" group.

Occasionally, what are usually regarded as the best witnesses to the text appear to agree in error. This is the case of $\mathrm{Hg}$ and $\mathrm{El}$ in line 1067

13. In Appendix A, I have highlighted similar examples. 
of the "Clerk's Tale." At this point both manuscripts read: "Shal be myn heir, as I haue ay supposed." The variant distribution in the rest of the witnesses is:

supposed ] Bo2 Cn El En 3 Gg Hg Ldı Mc Mm Pn Ra4 Ryı

disposid ] Boı Bw $\mathrm{Cx}^{1}$ Dd Dsı Enı En2 Hk Lc Ne Raı Tol

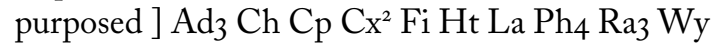

The Hengwrt and Ellesmere readings are the result of eyeskip from line 1065 ("This is thy doghter, which thow hast supposed"). The $\mathrm{Cx}^{2}$ reading, "purposed," is attested by at least six independent lines of descent. Moreover, it is the lectio dificilior and, for that reason, likely to be trivialized to the more modern form "disposed." Although the move from "purposed" to "disposed" can be explained as a trivialization, a hypothetical move from "disposed" to "purposed" is very unlikely to have happened. The best explanation here is that "purposed" is the archetypal reading, and might have stood in the exemplar or exemplars copied separately by Scribe B into the $\mathrm{Hg}$ and $\mathrm{El}$ copies — and both times the scribe made the same mistake and wrote "supposed" not "purposed."

In line 484 of the "Wife of Bath's Prologue" we find that a nonsensical reading was introduced in $\mathrm{Cx}^{2}$ ("I made hym of the same wode a troce"), while $\mathrm{Cx}^{1}$ had the word "croce" (which makes complete sense given the context). At this particular point, the variant distribution is:

troce ] $\mathrm{Cx}^{2} \mathrm{Hg} \mathrm{Ad}_{3} \mathrm{Ch} \mathrm{Ad}_{1} \mathrm{Hk} \mathrm{Pn} \mathrm{Wy}$

croce ] Bo1 Bo2 Bw Cn Cp Cxi Dd Ds D1 El En 3 Fi Gg Gl Ha2 $\mathrm{Ha}_{4}$ $\mathrm{Ha}_{5} \mathrm{He} \mathrm{Ht}$ Ii La Lc Ld1 Ld2 Ln Ma Mg Mm Ne N1 Ph2 $\mathrm{Ph}_{3} \mathrm{Ps}_{3}$ Py Rys Ry2 Si Se Tc1 Tc2 To

hood ] Mc Ral

groce ] $\mathrm{Ra}_{3}$

Although the reading "troce" is nonsensical, it is shared among several witnesses - $\mathrm{Cx}^{2}, \mathrm{Hg}, \mathrm{Ad}_{3}, \mathrm{Ch}, \mathrm{Ad}_{1}, \mathrm{Hk}, \mathrm{Pn}$, and $\mathrm{Wy}$, including four manuscripts $\mathrm{Hg}, \mathrm{Ad}_{3}, \mathrm{Ch}$, and $\mathrm{Hk}$ identified as “O.” Peter Robinson has suggested that this reading originated in an error that was present in the archetype. ${ }^{14}$

The above examples show the changes Caxton introduced derive from a manuscript from a different branch of the tradition than that used for the first edition, a manuscript likely closer to the archetype.

14. Peter Robinson, "A Stemmatic Analysis of Fifteenth-Century Witnesses of Wife of Bath's Prologue" in Normal F. Blake and Peter M. W. Robinson, eds., The Canterbury Tales Project: Occasional Papers 2 (Oxford: Office for Humanities Communication, 1997), 103 . 


\section{Caxton's Editing of the "Canterbury Tales"}

The revisions introduced by Caxton amount to almost 3,000 instances of changes at the word level. These can be seen in Appendix B, which presents a summary of changes in each section of the Tales.

My research on Caxton's editions of the Tales indicates that it is very likely he wrote corrections from this better manuscript into an unbound copy of his first edition ${ }^{15}$ that then was the copy for the second edition. ${ }^{16}$ The conflated text that resulted from the corrections made by Caxton remained for years the most widely available text of the Tales. ${ }^{17} \mathrm{My}$ analysis confirms that Caxton was accurate in his preface. When preparing his second edition, he did have access to a manuscript nearer the archetype than his first edition, which textually belongs to the "b" group. $\mathrm{He}$ introduced many readings taken from this manuscript - thousands of them, in every part of the text except the prose - throughout the whole length of the Tales.

\section{ALTERNATIVE VIEWS ON CAXTON AS A PRINTER}

However, my suggestion that Caxton actually did in his second edition what he said he did in its preface disagrees with several recent studies. Norman Blake edited all Caxton's prefaces and other original writings and wrote a widely used monograph devoted to Caxton. Here is what Blake says of Caxton's second edition and the preface to it:

Although he [Caxton] expressed concern for the text of his first edition, this may have been little more than publisher's talk. He was not sufficiently worried that he felt he had to produce a completely new text. He thought it sufficient to make one or two minor adjustments. This somewhat cavalier attitude has by not means disappeared from the publishing trade today, so we should not be surprised to find it in Caxton. Few people today take a publisher's "blurb" at its face value, and there is no reason to do so with Caxton's prologues, which serve the same function. ${ }^{18}$

15. See Norman Blake, Caxton and His World, The Language Library (London: Deutsch, 1969), 104; England's, 99; Thomas Dunn, "The Manuscript Source of Caxton's Second Edition of the Canterbury Tales" (PhD diss., University of Chicago, 1939).

16. Hellinga maintains that only two compositors were at work during the printing of the second edition of the Canterbury Tales (Hellinga, Caxton, 61). In my edition of Caxton's Canterbury Tales, I put forward an argument for three rather than two compositors.

17. See W. W. Greg, "The Early Printed Editions of The Canterbury Tales," PMLA 39 (1924): 737-61, on the matter of how the four fifteenth-century printed editions of the Canterbury Tales relate to one another.

18. Blake, Caxton and His World, 104. 
Two major points can be drawn from this quotation: first, Caxton made only "one or two minor adjustments" to his second edition of the Tales; and second, he was not truthful in his prefaces because this is the way in which publishers have always behaved. Blake's wording ("Few people today") implies that Caxton was conducting himself like a modern publisher, writing a "blurb" to advertise his books, and thus the current distrust of modern publishers' claims can be applied to Caxton. One can trace the influence of Blake's criticism of Caxton in the writings of other scholars. For example, Beverly Boyd seems to be defending Caxton from accusations of lack of knowledge of the text, and she seems to relieve him of any blame when she points out that he never claimed to be a scholar:

His [Caxton's] knowledge of the texts of Chaucer's works was not that of an exegete of his own time, much less that of a present-day editor of Chaucer, though the printer himself never claimed such skill. In no case do we have copies or precise records of Caxton's sources for these books. Within these limitations the evidence is strong that he followed his texts closely except in the second edition of The Canterbury Tales, where he can be faulted for a serious mistake in judgement when he tried to correct the first edition from a manuscript obviously of a different textual tradition, though the circumstances were not altogether his fault. ${ }^{19}$

When Boyd refers to $\mathrm{Cx}^{2}$, she states that "he can be faulted for a serious mistake in judgment when he tried to correct the first edition from a manuscript obviously of a different textual tradition." It would be unfair to condemn Caxton for conflating texts from different recensions and for not recognizing this fact, given that the genetic groups for the witnesses of the text have been widely accepted as accurate only after Manly and Rickert's edition published in 1940: to suggest that Caxton should have had this knowledge is imposing an anachronistic judgment on a case that might be better served if approached synchronically.

Lotte Hellinga continues the same line of observations in her description of Caxton's second edition. Hellinga's assertion that Caxton made only a small number of textual corrections in thirteen of the Tales and virtually none at all in ten of the verse Tales appears to support Blake's argument:

Caxton's main concern when editing the text was to add lines of verse that had been omitted in his first edition (to a total of 277 lines) and to take out or replace

19. Beverley Boyd, "William Caxton," in Editing Chaucer: The Great Tradition, ed. Paul G. Ruggiers (Norman, OK: Pilgrim Books, 1984), 13-34. 


\section{Caxton's Editing of the "Canterbury Tales"}

lines which he now rejected as spurious (to a total of 89 lines ...). He made a small number of textual corrections, partly derived from his manuscript source and partly independent, in 13 of the Tales: Knight, Miller, Man of Law, Merchant, Franklin, Wife of Bath, Clerk, Canon's Yeoman, Pardoner, Shipman, Prioress, Monk and Nun's Priest. Ten Tales in verse and the two prose sections remained practically untouched: Reeve, Cook, Squire, Friar, Summoner, Second Nun, Physician, Sir Thopas, Melibee and Parson, with very little interference in the Tales of the Nun's Priest [sic] and the Manciple. ${ }^{20}$

Indeed, Hellinga's argument appears the more forceful because of the detail she presents: most of the changes (she suggests) were to add or remove whole lines (adding 277, removing 89), ${ }^{21}$ with few other changes. Included in her list of tales left "practically untouched" is the "Squire's Tale." Yet, my analysis of the "Squire's Tale" suggests that Caxton introduced some 120 changes into the second edition, drawn from the "better manuscript": approximately one change every five lines. Indeed, my analysis of Caxton's changes over the whole edition, presented in Appendix B, suggests that Caxton made some 2,900 changes in the 19,000 verse lines of the Tales, or a rate of one change every six lines.

Hellinga does not state from where she derived the account of the changes made by Caxton in $\mathrm{Cx}^{2}$, and particularly the apparently convincing listing of exactly which tales were and were not changed, which goes beyond anything said by either of the two scholars Hellinga here cites, Norman Blake or Thomas Dunn. However, it appears that her opinion derives from a misreading of Dunn. Dunn devotes his entire third chapter to listing all cases of "unique variants" in the second edition in the each tale, showing that there are rather few unique readings in the thirteen tales that Hellinga says had "a small number of textual corrections" and very few or none in the ten tales that she says "remained practically untouched." Instead of tales that have very few variants, Dunn is listing only the tales where there are very few or no "unique variants" (variants found only in $\mathrm{Cx}^{2}$ ). The great majority of variants indeed do also appear in other witnesses to the Tales, and we expect this, given Caxton's declaration that he took the variants from another manuscript and thus were current in the tradition. Dunn is fully aware of this, and goes to on to report and analyze in Chapter 4 all the variants between the two

20. Lotte Hellinga, Catalogue of Books Printed in the XVth Century Now in the British Library (London: HES \& DeGraaf Publishers, 2007), 11:132.

21. The total number of lines present in $\mathrm{Cx}^{2}$ but not in $\mathrm{Cx}^{1}$ is 324, not 277: it appears that Hellinga is here following Dunn, who gives the number 277. 
editions that appear in other selected witnesses (Hellinga does not refer to this chapter). Both Dunn's Chapter 4 and my own work show clearly that, contrary to Hellinga's opinion, every verse tale was substantially corrected. ${ }^{22}$

My research shows that in the 2,909 lines (counting only the short version of link 30) that were present in $\mathrm{Cx}^{1}$, at least 19,105 changes were introduced that significantly altered words; this means there were changes in about 15 percent of lines. No addition or deletion or substitution of complete lines has been taken into account here. ${ }^{23}$ If we add to this the fact that there are 244 "added" lines, with another eighty lines replacing eighty-two in $\mathrm{Cx}^{1}$, that thirty-one lines were deleted, and that there are fourteen instances of line rearrangement, it could hardly be said that Caxton did not revise his first edition. Whether these changes were the result of a business plan to sell more books or whether they were made to oblige a rich patron is not as important here as establishing that Caxton was truthful in his preface and demonstrating that the variants introduced in the second edition are the only extant evidence of what must have been a text extremely close to the archetype of the textual tradition.

The studies by Blake, Boyd, and Hellinga present a view of Caxton as careless and unreliable. If widely accepted, this would have a powerful effect on scholarship: one thinks particularly of the debate over the merits of Caxton's edition of Malory against the Winchester manuscript. In the most recent comprehensive survey of the Winchester and Caxton Malory texts, William Matthews accepts Blake's characterization of Caxton as driven by commercial imperatives but rejects (as does this study) Blake's assertion that Caxton made only "haphazard and minor changes," according to his own analysis of the changes made by Cax-

22. Joseph J. Gwara, in his review of Wykyn de Worde, Father of Fleet Street by James Moran (reprinted with an introduction by Lotte Hellinga and Mary Elder), has pointed out that she failed to call attention to the flagrant plagiarism carried out by Moran ("James Moran, Wynkyn de Worde, Father of Fleet Street," Variants 4 [2005]:340-351).

23. This number is the result of my initially computer-aided but ultimately manual collation. I have checked these results with VBase for the "Miller's Tale" and link 1 and discovered that $\mathrm{I}$ had the tendency to underestimate variants by around 20 percent; that is, the completely automated collation detected more variants than my manual one. At least in part, this can be attributed to the thorough correction that the collations and transcriptions underwent before finally being published. 
ton in $\mathrm{Cx}^{2} .{ }^{24}$ In his introduction to the posthumous publication of Matthews's analysis, Robert L. Kindrick concludes that "We are forced by the evidence to assume Caxton was serious in his interest in a good text and that he told the truth in his prologues." ${ }^{25}$ My research reinforces these conclusions. This study of the agreements between the readings introduced in the Caxton second edition and their consistent occurrence in manuscripts believed close to the archetype of the Tales affirms that Caxton did not just make many changes (as Matthews shows) but that he did have access to a "trewe and correcte" copy of the Tales, and that he made extensive and consistent use of this copy as the source for the revisions in his second edition. Unequivocally, Caxton was not careless in his preparation of his second edition of the Tales and we should take his claims in its prologue as truthful.

24. William Matthews, "Caxton and Chaucer: A Re-View," in The Malory Debate: Essays on the Texts of Le Morte Darthur, ed. Bonnie G. Wheeler, Robert L. Kindrick, and Michael Norman Salda (Cambridge: Boydell \& Brewer, 2000), 1-34. 25. Robert L. Kindrick, introduction, The Malory Debate, xxvii. 


\section{APPENDIX A}

\section{Variants in the "Squire's Tale"}

Variants in bold are instances that show that Caxton was using a different manuscript source. These variants could not have been introduced by conjecture, and the support of the tradition shows that they are present in manuscripts that are considered to be close to the archetype (such as $\mathrm{Hg}, \mathrm{El}$ and $\mathrm{Ch}$ ) and other independent lines of descent ( $\mathrm{Ad}_{3}, \mathrm{Bo}_{2}, \mathrm{Dd}$, and $\mathrm{Ha}_{4}$, for example).

\begin{tabular}{|c|c|c|c|c|}
\hline$\underline{\text { Var }}$ & $\underline{\text { Line }}$ & $\underline{\mathbf{C x}^{1}}$ & $\underline{\mathrm{Cx}}{ }^{2}$ & Witnesses agreeing with $\mathrm{Cx}^{2}$ \\
\hline$\overline{1}$ & 2 & on russy & russy & $\mathrm{Hg} \mathrm{E} 1 \mathrm{Ad} 3 \mathrm{Bo} 2 \mathrm{Ch} \mathrm{Cp} \mathrm{Dd} \mathrm{Ha} 4 \mathrm{La}$ \\
\hline 2 & 14 & tentir & center & $\mathrm{Hg}$ El Ad3 Bo2 Ch Cp Ha4 La \\
\hline 3 & 15 & and strong & strong & $\mathrm{El}$ \\
\hline 4 & 15 & \& in & in & $\mathrm{Hg}$ Ad3 Bo2 Ch Cp Dd Ha4 La \\
\hline 5 & 18 & $\mathbf{a}$ & so wel & Hg El Ad3 Bo2 Ch Cp Dd Ha4 La \\
\hline 6 & 30 & I & It & $\mathrm{Hg}$ Ad3 Ch Cp Dd Gg La \\
\hline 7 & 32 & I & he & $\mathrm{Hg}$ El Ad3 Bo2 Ch Cp Dd Gg Ha4 La \\
\hline 8 & 41 & in & nyghe & Hg El Ad3 Bo2 Ch Cp Dd Ha4 La \\
\hline 9 & 46 & That & What & $\mathrm{Hg}$ El Ad3 Bo2 Ch Cp Dd Ha4 La \\
\hline 10 & 47 & Wel & Full & $\mathrm{Hg}$ El Ad3 Bo2 Ch Cp Dd Ha4 La \\
\hline 11 & 48 & ayen here & them & $\mathrm{Hg}$ El Ad3 Bo2 Ch Cp Dd Ha4 La \\
\hline 12 & 50 & And so this kyng & Thys Cambuscan & Hg El Ad3 Ch Cp Dd Ha4 La \\
\hline 13 & 53 & holdith & holte & $\mathrm{Hg}$ El Ad3 Ch Cp Dd Ha 4 La \\
\hline 14 & 53 & feste & feste so & El Ad3 Dd En1 \\
\hline 15 & 69 & that this & thys & Unique in $C x^{2}$ \\
\hline 16 & 69 & in his high & thus in his & $\mathrm{Hg}$ El Ad3 Bo2 Ch Cp Dd Gg Ha4 La \\
\hline 17 & 70 & thing & thynges & $\mathrm{Hg}$ El Ad3 Bo2 Ch Cp Dd Gg Ha4 La \\
\hline 18 & 72 & sodeynly & all sodeynly & $\mathrm{Hg}$ El Ad3 Bo2 Ch Cp Dd Gg Ha4 La \\
\hline 19 & 73 & bras & of bras & $\mathrm{Hg}$ El Ad3 Bo2 Ch Cp Dd Gg Ha4 La \\
\hline 20 & 75 & And on his & Vpon hys & $\mathrm{Hg}$ El Ad3 Bo2 Ch Cp Dd Gg Ha4 La \\
\hline 21 & 83 & He saluyd & Saluyth & $\mathrm{Hg}$ El Ad3 Bo2 Ch Cp Dd Gg Ha4 La \\
\hline 22 & 83 & the kyng & kynge & $\mathrm{Hg}$ El Ad3 Bo2 Ch Dd Gg \\
\hline 23 & 88 & com & were come & $\mathrm{Hg}$ El Ad3 Bo2 Ch Dd Gg \\
\hline 24 & 90 & lord & bord & $\mathrm{Hg}$ El Ad3 Bo2 Ch Cp Dd Gg Ha4 La \\
\hline 25 & 93 & faylle & vyce & Hg El Ad3 Bo2 Ch Cp Dd Gg Ha4 La \\
\hline 26 & 95 & Accordyng & Accordant & $\mathrm{Hg}$ El Ad3 Bo2 Ch Cp Dd Gg Ha4 La \\
\hline 27 & 95 & word & wordys & $\mathrm{Hg}$ El Ad3 Bo2 Ch Cp Dd Gg Ha4 La \\
\hline 28 & 98 & hille & style & Hg El Ad3 Bo2 Ch Cp Dd Gg Ha4 La \\
\hline 29 & 100 & that & al that & $\mathrm{Hg}$ El Ad3 Bo2 Ch Cp Dd Gg Ha4 La \\
\hline 30 & 101 & I & that I & $\mathrm{Hg}$ El Bo2 Ch Cp Dd Gg Ha4 La \\
\hline 31 & 111 & to & in to & $\mathrm{Hg}$ El Ad3 Bo2 Ch Cp Dd Gg Ha4 La \\
\hline 32 & 113 & thorough out & thorough & $\mathrm{Hg}$ El Ad3 Bo2 Ch Cp Dd Gg Ha4 La \\
\hline 33 & 120 & knoweth & couthe & $\mathrm{Cp} \mathrm{Ha} 4 \mathrm{La}$ \\
\hline 34 & 123 & skyl & seal & $\mathrm{Hg}$ El Ad3 Bo2 Ch Cp Dd Gg Ha4 La \\
\hline 35 & 130 & Hath & $\mathrm{Had}$ & Unique in $C x^{2}$ \\
\hline 36 & 130 & in & on & $\mathrm{Hg}$ Ad3 Bo2 Ch Cp Dd Gg Ha4 La \\
\hline 37 & 152 & it woundith & is wounded & $\mathrm{Hg}$ El Ad3 Bo2 Ch Cp Dd Gg Ha4 La \\
\hline 38 & 157 & hem & hym & $\mathrm{Hg}$ El Ad3 Bo2 Ch Cp Dd Gg Ha4 La \\
\hline 39 & 166 & kept & fette & Hg E1 Ad3 Bo2 Ch Cp Dd Gg Ha4 La \\
\hline
\end{tabular}




\begin{tabular}{|c|c|c|c|c|}
\hline Var & Line & $\mathrm{Cx}^{1}$ & $\mathrm{Cx}^{2}$ & Witnesses agreeing with $\mathrm{Cx}^{2}$ \\
\hline 40 & $\overline{168}$ & the tour & the hygh tour & $\mathrm{Hg} \mathrm{El} \mathrm{Ad} 3 \mathrm{Bo} 2 \mathrm{Ch} \mathrm{Cp}_{\mathrm{p}} \mathrm{Dd} \mathrm{Gg} \mathrm{Ha} 4 \mathrm{La}$ \\
\hline 41 & 175 & may hit & may hyt not & Unique in $C x^{2}$ \\
\hline 42 & 186 & of & at & Dd \\
\hline 43 & 193 & of & $\mathrm{a}$ & Hg El Ad3 Bo2 Ch Dd En1 \\
\hline 44 & 194 & demede & they demed & $\mathrm{El} \mathrm{Gg} \mathrm{Ha} 4 \mathrm{Ht}$ \\
\hline 45 & 202 & grekis & troye & Hg El Ad3 Bo2 Ch Cp Dd Gg Ha4 La \\
\hline 46 & 212 & thoughtis & doubtes & Hg El Ad3 Bo2 Ch Dd Gg Ht \\
\hline 47 & 215 & boundis & lewdnes & Hg El Ad3 Bo2 Ch Cp Dd Gg Ha4 La \\
\hline 48 & 224 & alteon & alocen & Hg El Ad3 Bo2 Ch Cp Dd Gg La \\
\hline 49 & 231 & for his & wyth hys & $\mathrm{ElGg}$ \\
\hline 50 & 239 & speke & speke they & $\mathrm{Hg}$ El Ad3 Bo2 Ch Cp Dd Gg Ha4 La \\
\hline 51 & 242 & be moyses & he moyses & $\mathrm{Hg}$ El Ad3 Bo2 Ch Cp Dd Gg Ha 4 La \\
\hline 52 & 242 & be kyng & kyng & $\mathrm{Hg}$ El Ad3 Bo2 Ch Cp Dd Gg Ha4 La \\
\hline 53 & 246 & fern glas & fern asshes glas & Hg El Ad3 Bo2 Ch Cp Dd Gg Ha4 La \\
\hline 54 & 250 & be & on & $\mathrm{Hg}$ El Ad3 Bo2 Ch Cp Dd Ht \\
\hline 55 & 270 & There & Here & [none] \\
\hline 56 & 273 & as festliche & a festliche & $\mathrm{Hg}$ El Ad3 Bo2 Ch Cp Dd Gg Ha4 La \\
\hline 57 & 273 & as fresh may & as fressh as may & $\mathrm{Hg}$ El Ad3 Bo2 Ch Cp Dd Ha4 La \\
\hline 58 & 275 & Who & Hou & Unique in $C x^{2}$ \\
\hline 59 & 277 & And therto suche & Suche & Hg El Ad3 Bo2 Ch Cp Dd Gg Ha4 La \\
\hline \multirow[t]{2}{*}{60} & 277 & lokyngis & lokyng and dyss & gis \\
\hline & & & & Hg El Ad3 Bo2 Ch Cp Dd Gg Ha4 La \\
\hline 61 & 278 & preysinges & perseyuyngis & $\mathrm{Hg}$ El Ad3 Bo2 Ch Cp Dd Gg Ha4 La \\
\hline 62 & 285 & squiers & squyerye & Dd En1 \\
\hline 63 & 289 & haue that & soupen al by & Hg El Ad3 Bo2 Ch Cp Dd Gg Ha4 La \\
\hline 64 & 290 & you & me & $\mathrm{E} 1 \mathrm{Gg}$ \\
\hline 65 & 300 & suche a & suche & Unique in $C x^{2}$ \\
\hline 66 & 307 & if yow & whan you & $\mathrm{Hg}$ El Ad3 Bo2 Ch Cp Dd Gg Ha4 La \\
\hline 67 & 311 & contre & contre that & $\mathrm{Hg}$ El Ad3 Bo2 Ch Cp Dd Gg La \\
\hline 68 & 315 & wol & wold & Unique in $C x^{2}$ \\
\hline 69 & 315 & al your & your & $\mathrm{Hg}$ El Ad3 Ch Cp Dd Gg Ha4 La \\
\hline 70 & 316 & wolde & wol & $\mathrm{Hg} \mathrm{El} \mathrm{Ad} 3 \mathrm{Bo}_{2} \mathrm{Ch} \mathrm{Cp}$ Dd Gg Ha4 Ht \\
\hline 71 & 317 & hadde & hath & Unique in $C x^{2}$ \\
\hline 72 & 332 & in to & to & Unique in $C x^{2}$ \\
\hline 73 & 339 & digestiouns & dygestion & $\mathrm{Hg}$ El Ad3 Bo2 Ch Cp Dd Gg Ha4 La \\
\hline 74 & 345 & Cherisshed & Cherisshe & $\mathrm{Hg}$ El Ad3 Bo2 Ch Cp Dd Gg Ha4 Ht \\
\hline 75 & 350 & where & were & $\mathrm{Hg}$ El Ad3 Bo2 Ch Cp Dd Gg Ha4 La \\
\hline 76 & 355 & hadde & hath & $\mathrm{Ha} 4$ \\
\hline 77 & 360 & ioye & a Ioye & $\mathrm{Hg}$ El Ad3 Bo2 Ch Cp Dd Gg Ha4 La \\
\hline 78 & 362 & chaungith & chaungyd & $\mathrm{Hg}$ El Ad3 Bo2 Ch Cp Dd Gg Ha4 La \\
\hline 79 & 363 & for here & ryght for & Hg El Ad3 Bo2 Ch Cp Dd Gg Ha4 La \\
\hline 80 & 363 & impression & the impression & En1 \\
\hline 81 & 378 & ten & four & Hg El Ch Dd Gg \\
\hline 82 & 379 & higher was she & hygher was he & $\mathrm{Hg}$ El Ad3 Ch Cp Dd Gg \\
\hline 83 & 383 & but & but wyth & $\mathrm{Hg}$ El Ad3 Bo2 Dd Gg Ha4 Ht \\
\hline 84 & 384 & ferre & forth & $\mathrm{Hg}$ El Ad3 Bo2 Ch Dd Gg Ht \\
\hline 85 & 394 & lust & the lust & Dd En1 \\
\hline 86 & 397 & prolixite & hys prolixyte & $\mathrm{Hg}$ El Ad3 Bo2 Cp Dd Gg Ht \\
\hline
\end{tabular}




\begin{tabular}{|c|c|c|c|c|}
\hline$\underline{\text { Var }}$ & $\underline{\text { Line }}$ & $\mathrm{Cx}^{1}$ & $\mathrm{Cx}^{2}$ & Witnesses agreeing with $\mathrm{Cx}^{2}$ \\
\hline .87 & 400 & an ende & sone an ende & $\mathrm{Hg}$ El Ad3 Bo2 Ch Cp Dd Gg Ha4 La \\
\hline 88 & 408 & tre & tre there & $\mathrm{Hg}$ El Ad3 Bo2 Ch Cp Dd Gg Ha4 La \\
\hline 89 & 410 & she pyght & to twyght & Unique in $C x^{2}$ [but Dd "so twight"] \\
\hline 90 & 411 & cruel & so cruel & $\mathrm{Hg}$ El Ad3 Ch Dd Gg Ht \\
\hline 91 & 413 & wolde & nold & $\mathrm{Hg}$ El Ad3 Bo2 Ch Cp Dd Gg Ha 4 La \\
\hline 92 & 417 & Or & That & $\mathrm{Hg}$ El Ad3 Bo2 Ch Cp Dd Gg Ha4 La \\
\hline 93 & 419 & of & and & $\mathrm{El} \mathrm{Gg}$ \\
\hline 94 & 429 & She hath & Hath & $\mathrm{Hg}$ El Ad3 Bo2 Ch Cp Dd Gg Ha4 La \\
\hline 95 & 430 & routhe & the routhe & $\mathrm{Hg}$ El Ch Cp Dd Gg La \\
\hline 96 & 430 & she & almost she & $\mathrm{Hg}$ E1 Ad3 Bo2 Ch Cp Dd Gg La \\
\hline 97 & 436 & where & there & Unique in $C x^{2}$ \\
\hline 98 & 442 & ellis & losse & $\mathrm{Hg}$ E1 Bo2 Ch Cp Dd Gg La \\
\hline 99 & 444 & causith & causen & $\mathrm{Hg}$ Ad3 Bo2 Ch Cp Dd Gg Ha4 La \\
\hline 100 & 446 & For & For ye & $\mathrm{Hg}$ El Ad3 Bo2 Ch Cp Dd Gg Ha4 La \\
\hline 101 & 446 & wolde wreke & ye wreke & $\mathrm{Hg}$ El Ad3 Ch Cp Dd Ha4 Ht \\
\hline 102 & 447 & Whiche that & Whyche & $\mathrm{Hg}$ El Ad3 Bo2 Ch Dd Gg La \\
\hline 103 & 447 & Ire & loue & ElGg \\
\hline 104 & 459 & yf that & yf & $\mathrm{Hg}$ El Ad3 Bo2 Ch Cp Dd Gg Ha4 La \\
\hline 105 & 464 & more & yet more & $\mathrm{Hg}$ Ad3 Ch Cp Dd Ht \\
\hline 106 & 467 & y take & take & $\mathrm{Hg}$ E1 Ad3 Bo2 Ch Cp Dd Gg La \\
\hline 107 & 472 & is & hys & $\mathrm{Hg}$ El Ad3 Bo2 Ch Cp Dd Gg Ha4 Ht \\
\hline 108 & 483 & the & the the & Unique in $C x^{2}$ \\
\hline 109 & 491 & day & hard day & El Gg \\
\hline 110 & 499 & That is & It was so & $\mathrm{Hg}$ El Ad3 Bo2 Ch Dd Gg Ht \\
\hline 111 & 502 & no wight wolde & I ne coude & El Gg \\
\hline 112 & 506 & loue & loues & $\mathrm{Hg}$ Ad3 Bo2 Ch Cp La \\
\hline 113 & 506 & this Ipocryte & Ipocryte & $\mathrm{Hg} \mathrm{Ad} 3 \mathrm{Bo} 2 \mathrm{Ch} \mathrm{Cp} \mathrm{La}$ \\
\hline 114 & 514 & noman & none & $\mathrm{Hg}$ El Ad3 Bo2 Ch Cp Dd Gg Ha4 Ht \\
\hline 115 & 521 & Graunte & Graunted & $\mathrm{Hg}$ El Ad3 Bo2 Ch Cp Dd Gg Ha4 La \\
\hline 116 & 531 & grauntid hym & had grauntyd & $\mathrm{Hg}$ El Ad3 Bo2 Ch Dd Gg Ht \\
\hline 117 & 538 & in & of & $\mathrm{Hg}$ El Ad3 Bo2 Ch Cp Dd Gg Ha4 La \\
\hline 118 & 539 & ioye & the Ioye & $\mathrm{Hg}$ E1 Ad3 Bo2 Ch Cp Dd Gg La \\
\hline 119 & 558 & herde & felte & Hg El Ad3 Bo2 Ch Cp Dd Gg Ha4 La \\
\hline 120 & 562 & aftir & as fer as & $\mathrm{Hg}$ El Ad3 Bo2 Ch Cp Dd Gg Ha4 La \\
\hline 121 & 575 & mette & fette & Unique in $C x^{2}$ \\
\hline 122 & 575 & me leue & bleue & $\mathrm{Hg}$ El Ad3 Bo2 Ch Cp Dd Gg Ha4 La \\
\hline 123 & 577 & $\mathrm{y}$ & he & Unique in $C x^{2}$ \\
\hline 124 & 590 & Bothe & Be ye & Unique in $C x^{2}$ \\
\hline 125 & 600 & repeyrith & repeyryng & $\mathrm{Hg}$ El Ad3 Bo2 Ch Cp Dd Gg Ha4 \\
\hline 126 & 604 & they & theyh & $\mathrm{Hg}$ El Ad3 Ch Cp Dd Gg Ha $4 \mathrm{La}$ \\
\hline 127 & 607 & his & that hys & $\mathrm{Hg}$ El Ad3 Bo2 Ch Cp Dd Gg Ha4 La \\
\hline 128 & 623 & arm & barm & $\begin{array}{l}\mathrm{Hg} \text { El Ad3 Bo2 Ch Cp Dd La } \\
\text { (GgHa4 omit })\end{array}$ \\
\hline 129 & 631 & plastris & salues & $\begin{array}{l}\text { Ad3 Bo2 Ch Cp Dd La } \\
\text { (Gg Ha4 omit; Hg El “saues") }\end{array}$ \\
\hline 130 & 638 & y peyntid & is peyntid & $\begin{array}{l}\mathrm{Hg} \text { El Ad3 Bo2 } \mathrm{Ch} \text { Cp Dd La } \\
\text { (Gg Ha4 omit) }\end{array}$ \\
\hline 131 & 650 & processe & my processe & $\mathrm{Hg}$ El Ad3 Bo2 Ch Dd (Gg Ha4 omit) \\
\hline 132 & 664 & Mercurius & Mercurius hous & He El Ad3 Ch Cp \\
\hline
\end{tabular}




\section{Caxton's Editing of the "Canterbury Tales"}

\section{APPENDIX B}

\section{Variants by Tale}

The tales in bold are the ones Hellinga considers "practically untouched."

1. General Prologue

2. Knight's Tale

3. Link 1

4. Miller's Tale

5. Link 2

6. Reeve's Tale

7. Link 3

8. Cook's Tale

9. Link 7

10. Man of Law's Tale

11. Link 15

12. Merchant's Tale

13. Link 8

14. Squire's Tale

15. Link 20

16. Franklin's Tale

17. Wife of Bath's Prologue

18. Wife of Bath's Tale

19. Link 10

20. Friar's Tale

21. Link 11

22. Summoner's Tale

23. Clerk's Tale

24. Link 13

25. Link 14

26. Nun's Tale

27. Link 33

28. Canon's Yeoman's Tale

29. Physician's Tale

30. Link 21

31. Pardoner's Tale

32. Shipman's Tale

33. Link 24

34. Prioresse's Tale

35. Link 25

36. Tale of Thopas

37. Link 28

38. Tale of Melibee

39. Link 29

40. Monk's Tale
150 significant changes (858 lines)

448 significant changes (2244 lines)

12 significant changes (76 lines)

79 significant changes (666 lines)

14 significant changes (66 lines)

93 significant changes (404 lines)

4 significant changes (40 lines)

7 significant changes (58 lines)

22 significant changes (98 lines)

188 significant changes (1064 lines)

6 significant changes (32 lines)

225 significant changes (1174 lines)

7 significant changes (28 lines)

123 significant changes (664 lines)

(not present in $\mathrm{Cx} 1)^{26}$

197 significant changes (908 lines)

140 significant changes (830 lines)

62 significant changes (406 lines)

2 significant changes ( 36 lines)

53 significant changes (365 lines)

14 significant changes (44 lines)

87 significant changes (586 lines)

187 significant changes (1176 lines)

4 significant changes (36 lines)

1 significant change (7 lines)

45 significant changes (553 lines)

14 significant changes (160 lines)

92 significant changes (762 lines)

53 significant changes (286 lines)

4 significant changes (40 lines)

90 significant changes (640 lines)

57 significant changes (454 lines)

3 significant changes (18 lines)

41 significant changes (238 lines)

2 significant changes ( 21 lines)

23 significant changes (205 lines)

8 significant changes (48 lines)

35 significant changes (918 lines)

7 significant changes (102 lines)

96 significant changes (680 lines)

26. Link 20 has a total of 36 lines and link 31 has a total of 16 lines; these are not taken into account here because they are accounted for in the line substitutions, additions and deletions. 
41. Link 30

42. Nun's Priest's Tale

43. Link 31

44. Link 36

45. Manciple's Tale

46. Link 37

47. Parson's Tale

48. Chaucer's Retraction
10 significant changes ( 34 lines, short version)

100 significant changes (626 lines)

(not present in $\mathrm{Cx} 1$ )

14 significant changes (104 lines)

28 significant changes (258 lines)

11 significant changes (74 lines)

50 significant changes (1006 lines)

1 significant change (12 lines) 


\section{Caxton's Editing of the "Canterbury Tales"}

APPENDIX C

Witness Sigils

\section{Manuscripts}

Adı London, British Library, MS. Add. 5140

$\mathrm{Ad}_{3}$ London, British Library, MS. Add. 35286

Bor Oxford, Bodleian Library, MS. Bodl. 414

Bo2 Oxford, Bodleian Library, MS. Bodl. 686

Bw Oxford, Bodleian Library, MS. Barlow 20

Ch Oxford, Christ Church College, MS. 152

Cp Oxford, Corpus Christi College, MS. 198

Dd Cambridge, University Library, MS. Dd.4.24

Dsı Tokyo, Takamiya MS 32 (ex Devonshire)

E1 California, San Marino, Huntington Library, MS. E1. 26 C 9 (Ellesmere)

Enı London, British Library, MS. Eg. 2726

En2 London, British Library, MS. Eg. 2863

En3 London, British Library, MS. Eg. 2864

Fi Cambridge, Fitzwilliam Museum, MS. McClean 181

Gg Cambridge, University Library, MS. Gg.4.27

Ha4 London, British Library, MS. Harley 7334

Ha5 London, British Library, MS. Harley 7335

He New Jersey, Princeton University Library, MS. 100 (Helmingham)

$\mathrm{Hg}$ Aberystwyth, National Library of Wales, MS. Peniarth 392 D (Hengwrt)

Hk Norfolk, Holkham Hall, MS. 667

Ht Oxford, Bodleian Library, MS. Hatton Donat.1

Ii Cambridge, University Library, MS. Ii.3.26

La London, British Library, MS. Lansdowne 851

Lc Lichfield Cathedral, MS. 29

Ldı Oxford, Bodleian Library, MS. Laud Misc. 600

Ld2 Oxford, Bodleian Library, MS. Laud Misc.739

Ln Lincoln Cathedral Library, MS. 110

Ma University of Manchester, John Rylands Library, MS. English 113

Mc Chicago, University of Chicago Library, MS. ${ }_{56}$ (McCormick)

Mg New York, Pierpont Morgan Library, MS. 249

Mm Cambridge, University Library, MS. Mm.2.5 
$\mathrm{Ne}$ Oxford, New College, D.314

N1 Northumberland, Alnwick Castle, MS. 455

$\mathrm{Ph}_{2}$ Geneva, Bodmer Library, MS. 48 (Phillipps 8136)

$\mathrm{Ph}_{3}$ Philadelphia, Rosenbach Museum and Library, MS. 1084/1 (Phillipps 8137)

$\mathrm{Ph}_{4}$ California, San Marino, Huntington Library, MS. HM 140 (Phillipps 8299)

Ps Paris, Bibliothèque Nationale, MS. Fonds Anglais 39

Ral Oxford, Bodleian Library, MS. Rawl. poet.141

Ra3 Oxford, Bodleian Library, MS. Rawl. poet.223

Ra4 Oxford, Bodleian Library, MS. Rawl. poet C.86

Ryı London, British Library, MS. Royal ${ }_{17}$ D.XV

Ry2 London, British Library, MS. Royal 18 C.II

Si Tokyo, Takamiya 22 (Sion College)

Tc1 Cambridge, Trinity College, MS. R.3.3

Tc2 Cambridge, Trinity College, MS. R.3.15

To1 Oxford, Trinity College, MS. 49

Pre-1501 Printed Editions

$\mathrm{Cx}^{1}$ Caxton, first edition (c. 1476)

$\mathrm{Cx}^{2}$ Caxton, second edition (c. 1482)

Pn Pynson (1492)

Wy Wynkyn de Worde (1498) 


\title{
Henry Delahay Symonds and James Ridgway's Conversion from Whig Pamphleteers to Doyens of the Radical Press, 1788-1793
}

\author{
Peter Robinson
}

\author{
The Whig-Dog! \\ Monthly Review 4, 1791
}

$\mathrm{I}^{2}$ N HIS REviEw of the sixth, enlarged edition of Lessons to a Young Prince (1790), ${ }^{1}$ which appeared in the Monthly Review, the classicist and historian John Gillies followed a persistent tendency in contemporary criticism to read (and to dismiss) Lessons as "another Whig tract," despite its appeal for the non-partisan consideration of alternative political constitutions and trenchant disavowal of any party interest. ${ }^{2}$ In his dis-

1. David Williams, Lessons to a Young Prince, on the Present Disposition in Europe to a General Revolution (London: H.D. Simmons, 179o). A popular political pamphlet, it went through seven editions within a year. The first edition was anonymous and misspelled the publisher's name on the title page. Subsequent editions bore the pseudonym, "Old Statesman." For an account of issues surrounding Lessons' anonymity see, Peter Robinson, "Authorship and the Role of Anonymity and Pseudonymity in David Williams's Lessons to a Young Prince," The Hiyoshi Review of English Studies 57 (2010): 49-81.

2. Monthly Review (4 March 1791):346. See W. W. Wroth and the Rev. I. C. Cunningham, "Gillies, John (1747-1836)," ODNB (Oxford: Oxford University Press, 2004) doi: 10.1093/ref:odnb/10744; Richard B. Sher, The Enlightenment and the Book: Scottish Authors \& their Publishers in Eighteenth-Century Britain, Ireland, E America (Chicago \& London: University of Chicago Press, 2006), 367-68.

Peter Robinson (The University of Tokyo, 3-8-1 Komaba, Meguro-ku, Tokyo, Japan, 1538902) is Associate Professor in the Department of English Language, College of Arts and Sciences. He is co-author of several books on local history, including Stanmer Eं the Pelham Family (2007), and has presented and published widely on eighteenth-century culture, from literary anonymity and advertising, to Jean-Jacques Rousseau's philosophy of history. 
missal of the pamphlet's author, Gillies even enlisted the support of the not-so-long departed Samuel Johnson, who after cursorily perusing the work, tossed it to one side exclaiming “The Whig-dog!” Gillies's diagnosis derived from his conflation of the perceived political values of its publishers Henry Delahay Symonds ${ }^{3}$ and James Ridgway with the text itself rather than through a careful examination of the political values that it expressed, indicating that the publishers found it hard to slough off their earlier associations with the Whig press. For by this time, they had become estranged from the party and its advocates and had embraced the radical reform circles that rotated around a number of leading authors and publishers incarcerated in Newgate prison.

Frustratingly few personal details are known about either Symonds or Ridgway, but what is clear is that they were both highly motivated publisher-booksellers, deeply politicized, and it is argued, politicizing men. Like so many of their contemporaries in the book trade, they were utterly committed to the cause of press freedom and the dissemination of political tracts encouraging parliamentary reform. Nevertheless, their political affiliations and orientation appear to have changed considerably between the years 1788 and 1793 , a critical period that spanned the entirety of their publishing association with David Williams's Lessons. For the two publisher-booksellers, these years represented a period of rapid ideological transition, from mainstream opposition publishers and booksellers tied to party purse strings, to full-blown independent political radicals. During this period they developed literary associations with such "trailblazers" as Thomas Paine, William Godwin, and John Cartwright while maintaining long-standing ties with some of the most popular satirists of their age, Peter Pindar (John Wolcot), Anthony Pasquin (John Williams), and David Williams heading the field. Both publisher-booksellers were also active in the wider parliamentary reform movement, taking prominent roles in numerous societies including the London Corresponding Society (LCS) and the Society for Freedom of the Press, and associating with the Society for Constitutional Information and Friends of the People. Finally, both shared a lengthy period in Newgate prison after convictions for seditious libel. Rejecting earlier but murky associations with the Whig faction led by Charles Fox, which was strongest during the "Regency Crisis" (1789-1790), in favor of greater

3. There are two main variant spellings: Henry de la Hay and Henry Delahoy, but the most frequently occurring spelling in contemporary published sources is Delahay, so I have used it throughout. 


\section{Symonds and Ridgway's Conversion}

independence in the choice of works and authors they published, by the final quarter of 1790 , along with other soon-to-be Newgate alumni Daniel Isaac Eaton and William Holt, they belonged to the top tier of self-confident publisher-booksellers, printing and disseminating vast quantities of pamphlets critical of both administration and opposition in the wake of the French Revolution controversy.

Although neither publisher-bookseller appears in the Dictionary of National Biography, evidence obtained from an analysis of the popular press in the late eighteenth century indicates that Ridgway had the higher profile of the two men as an active publisher-bookseller. ${ }^{4}$ This was probably due to the fashionable addresses of his shops, first at 1 York Street, St James's Square, and later at 170 Piccadilly - two locations not traditionally associated with the book trade and suggestive of both independence of mind and growing commercial confidence. ${ }^{5}$ Symonds on the other hand, concentrated more exclusively on publishing from his premises in the old book-quarter of Paternoster Row and received little contemporary comment; for example, his death in 1816 was not mentioned in the Gentleman's Magazine, unlike Ridgway's. ${ }^{6}$ However, in common with many publishers of the period, the pair collaborated on numerous publications covering a wide range of genres: political, historical, geographical, religious, fictional, whilst not balking at the scandalous and obscene. Although broad, their output was nevertheless characterized by its provocative nature, from the salacious to the seditious, covering all the major scandals and contentious political issues of the day, such as defending John Wilkes, Warren Hastings and John Horne Tooke.

4. The analysis is based on data searches using the English Short Title Catalogue, Copac, and Eighteenth-Century Collections Online.

5. See the entry for Ridgway in Ian Maxted, "The London Book Trades 1775-1800: A Checklist of Members," Exeter Working Papers in Book History, http://bookhistory. blogspot.com/2007/o1/london-1775-1800-r.htmlm accessed 15 August 2012. Ridgway was at 1 York Street, St. James's 1789-1804; 170, Piccadilly 1805-1821. See also Ian Maxted, The London Book Trades 1775-1800 (Surrey: Gresham Press, 1977), 188-220. For a description of the "Row" in the late eighteenth century, see James Raven, The Business of Books: Booksellers and the English Book Trade (New Haven \& London: Yale University Press, 2007), in which the "northern extremities" of St. James's and Piccadilly are described as "new (if sometimes transient) fashionable resorts for book and print buyers" (318). See also James Raven, "London and the Central Sites of the English Book Trade," in The Cambridge History of the Book in Britain Volume 5: 1695-1830, ed. Michael F. Suarez, SJ, and Michael Turner (Cambridge: Cambridge University Press, 2010), 293-308.

6. Gentleman's Magazine (June 1838): 666. 
Despite being in a de facto partnership throughout the 1790s, Symonds and Ridgway seldom shared an imprint, a decision born of prudence: if one publisher was imprisoned for libel or sedition, the other would superintend his partner's business, and vice versa. This has important implications for the publication of one of their most popular pamphlets of the period, Lessons, for although its title page indicated that it was exclusively published by Symonds, early advertising for the first edition made it clear that Ridgway held what amounted to a silent share in it, and it was also supported by a number of other London booksellers, all prepared to run the risk of distribution. ${ }^{7}$ Perhaps more tellingly, it was predominantly Ridgway who was responsible for advertising Lessons. Symonds and Ridgway's relationship was further strengthened, their public profile greatly enhanced, and their democratic credentials radicalized in 1791, when Symonds was charged with seditious libel and incarcerated in Newgate prison for the offense of publishing the second half of Thomas Paine's The Rights of Man. Later they were both up before Lord Kenyon at the King's Bench on 8 May 1793 for the same offense of seditious libel, this time for publishing the anonymous satire The Jockey Club and Paine's Address to the Addressers, as well as his The Rights of Man Part II. Given their mutual memberships in many of the leading radical reform clubs and societies related to press freedom and constitutional reform, with which Ridgway was particularly involved, for all intents and purposes they formed a symbiotic partnership of like minds. ${ }^{8}$ Their business relationship throughout the 179 os and early years

7. The advertisement for the first edition of Lessons ends, "Printed for H.D. Symonds and Mr. Baldwin, Paternoster Row, the Booksellers in Piccadilly, St James's Street, Pall Mall, The Strand, Fleet Street, Royal Exchange, J. Ridgway, York Street, St James's Square, and Mr. Lewis, Russell Street, Convent Garden" (The World 1162 [23 September 1790]).

8. For example, James Ridgway was general printer to the LCS. See Mary Thrale, ed., Selections from the Papers of the London Corresponding Society 1792-1799 (Cambridge: Cambridge University Press, 1983), 36. Symonds was a member of the Society's committee that decided to have twelve thousand copies of Paine's Letter Addressed to the Addressers printed and circulated. See John Horne Tooke, The Trial of John Horne Tooke, for High Treason, at the Sessions House in the Old Bailey (London: sold by Martha Gurney, 1795), 113. It is important to note that although cooperation between Symonds and Ridgway intensified during imprisonment, their publishing collaboration predated it. Further ties were cemented when James Leech Ridgway, Ridgway's eldest son, began working for Symonds, presumably as an apprentice: "I served time with Mr. Simmons [sic], in Paternoster-row, and then went into partnership with my brother." See Central Criminal Court Minutes of Evidence, Taken in Shorthand (London: George Herbert, 1836), 3:248-258. 


\section{Symonds and Ridgway's Conversion}

of the nineteenth century remained strong-strong enough for Symonds to bequeath his stock and copyrights to Ridgway upon his death, although it was William Sherwood, William Neely, and Thomas Jones who succeeded him. ${ }^{9}$ In 1854 , some sixteen years after Ridgway's death in 1838, an anonymous correspondent "R. R." wrote in Notes and Queries, "The Ridgways have been the great Whig pamphlet publishers for more than two-thirds of a century."10 The superlative was not hyperbole, but the correspondent's classification of James Ridgway as Whig does not accurately reflect his political position in the 1790 s when Lessons was published. The importance of James Ridgway in the world of political pamphlet publishing during the revolutionary period was, however, beyond dispute and fully recognized by his contemporaries: "scarcely any books are read but Political Pamphlets, the fashionable Booksellers are Stockdale, Jordan, Debrett and Ridgway," one contemporary noted in 1793, whilst even a hostile source conceded that in the 1790s, Ridgway's imprint on a title page was worth between $£_{1}, 000-1,500$ in the sales that it would generate. ${ }^{11}$ Symonds and Ridgway were publishers of some of the most important as well as best-selling political works in the final decade of the eighteenth century. As late as the end of the 1780 s, Symonds and Ridgway were associated with the opposition Whigs of Charles Fox, a connection demonstrated by the Monthly Review's review of Lessons, which alluded to it being in the same vein as many other opposition tracts published by them. This raises an important question: did readers come to Lessons pre-conditioned to read it in a particular way? Lucyle Werkmeister's work on eighteenth-century newspapers indicates that during the late $178 \mathrm{os}$, Ridgway was in the direct pay of Charles Brinsley Sheridan and the Prince of Wales's faction, yet hard evidence is scant due to the very nature of the transactions. ${ }^{12}$ Given the lack of primary documentary evidence, uncovering Symonds and Ridg-

9. Details of his last will, dated 18 December 1815 , can be found at The National Archives, UK, PROB $11 / 1583 / 340$.

10. Died 6 May 1838, in Piccadilly, aged 83 years. The entry begins, "Mr. James Ridgway, bookseller, the well-known pamphlet publisher" (Gentleman's Magazine [June 1838]: 666). See also Notes and Queries ser. 10, no. 267 (1854): 465.

11. The Country Spectator 13 (1 January 1793): 107.

12. The European Magazine, and London Review 2 (August 1782): 134-136, alludes to his political connections, "his [Williams's] present time seems to be taken up by secret services in politics, to young and old pupils, and public lectures on miscellaneous subjects" (136). 
way's influence on Williams or his composition of Lessons, and how it reflects the publishers' shifting political sympathies as well as those of its author, requires following a variety of different evidentiary trails. The Notes and Queries correspondent "R.R" ended his letter to the editor by optimistically noting "a reference to their [Ridgways'] accounts," which would "throw light on many literary obscurities," might still be had. ${ }^{13}$ Ralph A. Manogue repeated this appeal for archival material 130 years later, and from the responses he produced two important articles: "The Plight of James Ridgway, London Bookseller and Publisher, and the Newgate Radicals, 1792-1797," and "James Ridgway and America."14 (The former article became the basis for Iain McCalman's description of Ridgway, and to a lesser extent Symonds, in "Newgate in Revolution: Radical Enthusiasm and Romantic Counter Culture." ${ }^{15}$ ) These titles indicate how the two booksellers have been viewed by modern historians; other sources describe Ridgway variously as "radical," "Whig-radical," and "Jacobin." In fact, so important was Ridgway in the world of political pamphlet publishing that the writer of the obituary for his son James Leech Ridgway could not help mentioning the elder Ridgway, who had been "so earnest and zealous a champion in his advocacy of Liberal opinions, in the days 'when George the Third' was King, that he suffered more than one political prosecution, and was on one occasion imprisoned in Newgate on a charge of seditious publication."16 Although this Victorian obituary used the term "Liberal" to denote his political leanings, its characterization of the writer was much the same as that of three-quarters of a century earlier. On many occasions in the early 179os, Ridgway referred to his own opinions as "liberal," but always in the lower case, deliberately distinguishing them from any association with party. The writer for the Gentleman's Magazine was thus wrong to equate the political associations of the son with those of his father when he stated, "he [James Leech Ridgway] was for the greater part of his life connected as a publisher with the leading members of the Liberal Party, as his father had been before him."17

The first contemporary source hinting at Ridgway's political leanings appears in a 1784 attack on the reputation and character of John Stock13. Notes and Queries ser. 10, no. 267 (1854): 465.

14. Wordsworth Circle 27, no. 3 (1986): 158-66; Early American Literature 31, no. 3 (1986): 264-88.

15. Eighteenth-Century Life 22, no. 1 (1998): 95-110.

16. "Mr. James Leech Ridgway," Gentleman's Magazine (February 1863): 243. 17. Ibid. 


\section{Symonds and Ridgway's Conversion}

dale, written by the Rev. William Hamilton and published by Ridgway in the Intrepid Magazine. While clearly motivated by a feud between the related-by-marriage booksellers, many of the biographical details within the article provide valuable insights into the origins of the rivalries among key London booksellers and publishers of this period, and more importantly, their political networks. A cartoon caricature accompanying the article shows Stockdale in a blacksmith's shop, apron-clad, hammering on a thick book - a reference to his origins as a blacksmith's son - while behind him stands an ass tethered to a wall, accentuating the ridicule (see Fig. 1). The caption also calls him "one of the King's New Friends," a transparent allusion to his patronage by the Crown.

The article claims that Stockdale started in the trade under the wellknown publisher and writer John Almon, first as manager-porter, and later as manager of his newspaper distribution. Ridgway, Stockdale's brother-in-law, was sent for from Cheshire to work under his supervision. The article further alleges that the barely literate Stockdale was so uneducated that he relied upon his brother-in-law to complete even the most rudimentary of tasks: "during the period that his brother-in-law, Ridgway, lived with him, there was not a single form or receipt he was not first obliged to make out for him, and when Stockdale came to copy it he was obliged to tell him the letters into the bargain. ${ }^{.18}$ Later, Stockdale hatched a scheme to defraud Almon by keeping money given to him to pay distributors of the papers while actually delivering them himself, eventually amassing enough money from the enterprise to set up a small press on his own, taking many of Almon's customers with him..$^{19}$

Ironically, while Almon had many public political connections with the opposition, and Ridgway later forged ties with the Prince of Wales, in his article Hamilton berated Stockdale for his reliance on patronage by the Crown. ${ }^{20}$ Contemporary accounts portrayed Stockdale as a most

18. Intrepid Magazine 1 (1784): 54.

19. The $O D N B$ suggests that this was in 1781 , when John Almon retired to Box Moor, Hertfordshire, selling his business to Debrett. The author has been unable to trace any publications bearing Stockdale's name earlier than this date. For an authoritative account of John Almon, see Deborah Rogers, Bookseller as Rogue: John Almon and the Politics of Eighteenth-Century Publishing, University Studies Series IV, English Language and Literature Vol. 28 (New York: Peter Lang, 1986). Rogers's monograph notes that from 1780 onwards, Debrett's imprint appeared with Almon's in various combinations, occasionally even as "successor to Almon" (95).

20. See Hannah Barker, "Stockdale, John (c.1749-1814)," ODNB, doi:10.1093/ ref:odnb/26541. 


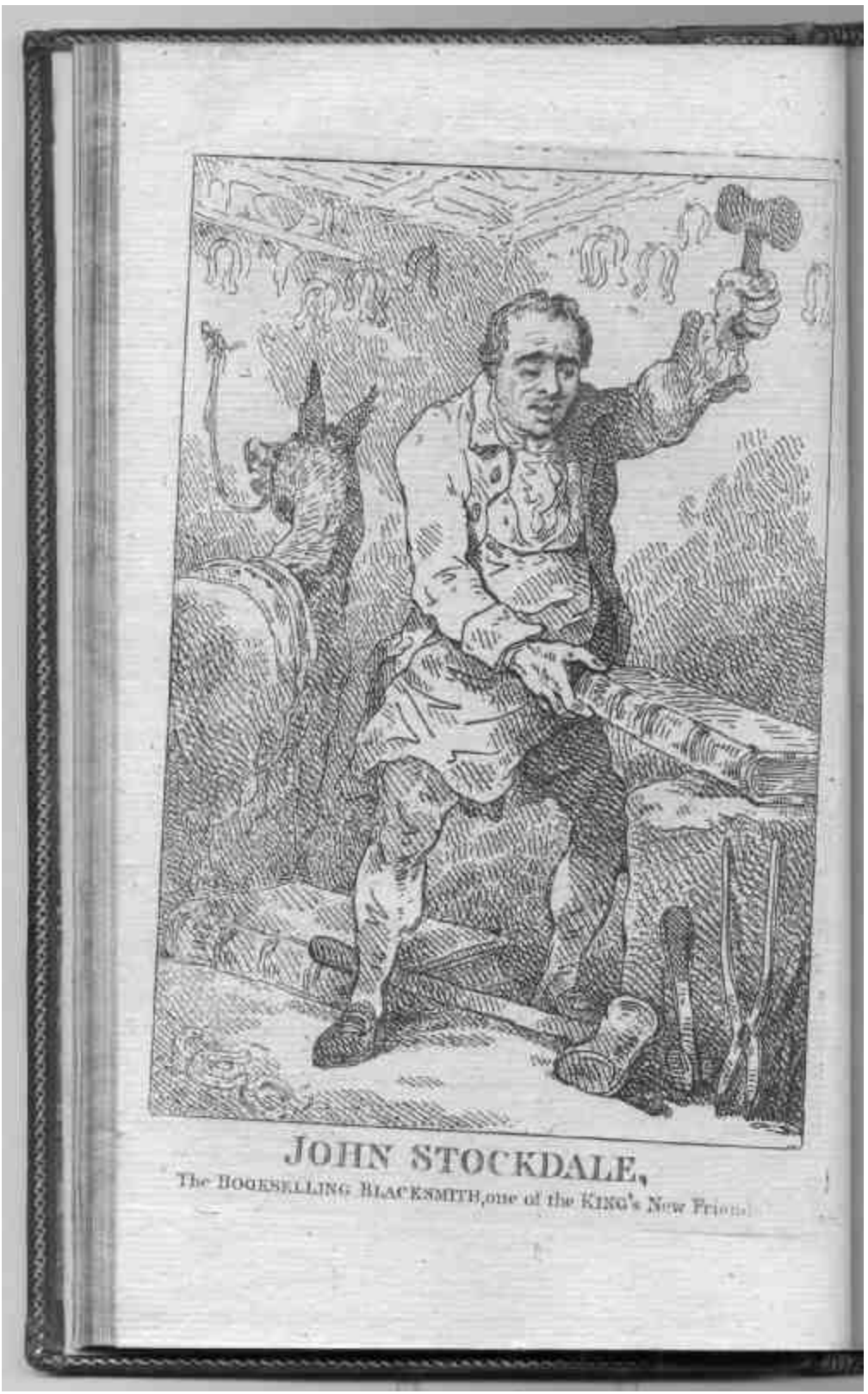

Fig. 1: "John Stockdale, The Bookselling Blacksmith," in The Intrepid Magazine 1 (1784): n.p. Courtesy of Special Collections, Spencer Research Library, University of Kansas Libraries. 


\section{Symonds and Ridgway's Conversion}

unsavory character, not above inducing prosecutions of rival booksellers: he once engineered a charge of piracy against the publisher Debrett that had no substance at all and was designed solely to put Debrett out of business when he, rather than Stockdale, succeeded to Almon's press. This attack was accompanied by a press campaign, working on the principle that, "by lessening the number of a competitor's friends [he would] increase his own."21 More importantly, the Hamilton article allows us to date the beginning of Ridgway's own publishing venture. Stockdale's antipathy toward Almon is described as being about "ten years back," and Hamilton characterizes Ridgway as a "younger beginner" during the period he aided Stockdale. Consequently, Ridgway likely started his own activities in the early $1780 \mathrm{os}$, by then familiar with the Whig-leaning clientele of Almon's shop that was, according to a contemporary, Alexander Stephens, frequented regularly by David Williams.22 This timeline also correlates with "R. R.'s" 1854 statement that the Ridgways had been operating for two-thirds of a century; and Maxted's research indicates that Ridgway was publisher of the London Courant from 1782 onwards, operating out of 116 The Strand. ${ }^{23}$

Unfortunately, little more is known of Symond's career other than the details found in his will. ${ }^{24}$ Maxted listed him as trading in Stationers' Alley in 1784, shortly after earning his freedom by redemption from an apprenticeship on 2 December 1783 , (also the year he married Jane Glover). ${ }^{25}$ There is no evidence of where Symonds or Ridgway obtained the capital to start their businesses or when the two first met, but clearly they shared the experience of nursing fledgling publishing and bookselling businesses in an already highly competitive and saturated market. It is a testament to the skill of Ridgway in particular that by the time

21. Intrepid Magazine 1 (1784): 55 .

22. Ibid., 53 .

23. At the time of the "R. R." letter, Ridgway's two sons were running the business, James Ridgway having died in 1838. See Ian Maxted, London Book Trades 17751800: A Preliminary Checklist of Members (Kent: William Dawson \& Sons, 1977), 188.

24. The will is dated 18 December 1815 . The lack of scholarship on Henry Delahay Symonds and his radicalism has been pointed out by Iain McCalman: "Symonds remains one of the most neglected of radical publishers of the 179os"; see "Patriots in Prison': Newgate Radicalism in the Age of Revolution," in Nerwgate in Revolution: An Anthology of Radical Prison Literature (London \& New York: Continuum, 2005), xxii.

25. McCalman, "Patriots," 270; see also D. F. McKenzie, ed., Stationers' Company Apprentices, 1701-1800 (Oxford: Oxford Bibliographical Society, 1978), 345. 
he published Royal Recollections for David Williams in 1788, along with Stockdale, Debrett, and Jeremiah Samuel Jordan, he was the most wellknown publisher of pamphlets in England.

In the years preceding Ridgway's imprisonment for seditious libel, he was viewed by contemporaries as a tacit supporter of the Fox Whigs, and many of the writers associated with his publishing house wrote openly for the Whig press, although not exclusively, often issuing satirical attacks that traversed the political divide. For example, David Williams's writings published by Ridgway in the late 1780 os were often much more measured in their criticism of Fox than of Pitt. ${ }^{26}$ Furthermore, as Deborah Rogers has shown, John Almon, who co-published four of Williams's works, was by 1786 firmly in support of the opposition and receiving subsidies from them. ${ }^{27} \mathrm{He}$ was also in France during the years 1786-92, fleeing charges for libelling Pitt, thus making any further publishing association with Williams all but impossible. This explains why Williams's next works were under Ridgway's imprint and indicate a relatively smooth transition from Almon to Symonds and Ridgway as Williams's main publishers (with no evident ideological upheaval).

In the murky world of late eighteenth-century book publishing and selling, it was commonplace for printers, publishers, and booksellers to exchange writs for alleged libels, prosecutions for treasonous or blasphemous material, and other legal tricks and claims by rival publishers. The trails left by litigation surrounding such legal disputes are important because they provide a window into the often-opaque connections between alleged political patrons, publisher-booksellers, and authors. Ridgway faced three legal disputes within a decade, including one directly involving Symonds, actions that give us insight into his changing political allegiances and increasing radicalization. In addition, Ridgway's activities on behalf of the London Corresponding Society brought him to the particular notice of the authorities, and he was subject to the observations of the government spy George Lynam, who reported regularly on his movements and actions.

Lucyle Werkmeister has argued that throughout the late 1780 os and early 179os, Ridgway had a close but troubled relationship with the

26. The most notable was Royal Recollections on a Tour to Cheltenham, Gloucester, Worcester and Places Adjacent in the Year 1788 (London: Ridgway, 1788).

27. A Letter to the Body of Protestant Dissenters; and to Protestant Dissenting Ministries of All Denominations (London: J. Almon and J. Wilkie, 1777); see also Rogers, Bookseller as Rogue, 99. 
Prince of Wales and his Fox entourage, as an examination of his publication of The Speech of the Right Hon. Charles James Fox: Containing the Declaration of His Principles (1792) demonstrates. ${ }^{28}$ Dissatisfaction with Fox's lack of political boldness in pursuing parliamentary reform culminated in Ridgway's leaving the Whig Party for the independent radical reform movements, which were characterized by a distrust of party. However, this transition did not occur instantaneously or permanently. Available evidence suggests that even as late as 1789 , just a year before the publication of Lessons, Ridgway was still on friendly terms with Carlton House and Fox's Whigs and was in all probability receiving some form of pecuniary advantage from the association. Indeed, even after Ridgway's publishing output turned more decidedly anti-Fox, they remained on cordial terms socially. ${ }^{29}$ Nonetheless, analysis of the titles he published in 1788 and 1789 show a decisive shift in political alignment, with the bulk of these works directly criticising the king, the government, or its ministers, whilst at the same time often extolling the opposition. Two titles characterize this shift from Whig to radical, both by Williams: Royal Recollections (1788) and Authentic Specimens of Ministerial Instructions $(1789)$. The former was an extremely popular satire on George III, while the latter attacked the administration and careerism of William Pitt. ${ }^{30}$ Both richly satirical works referred only occasionally to the opposition while lambasting and lampooning all the key ministers of the day, including Pitt, Edward Thurlow, Charles Jenkinson, and Henry Dundas. The Prince of Wales and Charles Fox were mentioned only briefly and only mildly criticized for their inability to make political capital out of the Regency Crisis. The second, less successful satire was dedicated entirely to attacking Pitt and his ministry. Increasingly, though, the focus of their works was more evenly distributed between parties, exhibiting a trend towards issue-related publication and the promotion of the concept of liberty, which transcended, or rather was increasingly defined as, independence from party.

28. The Speech of the Right Hon. Charles James Fox: Containing the Declaration of His Principles, Respecting the Current Crisis of Public Affairs, and a Reform in the Representation of the People. Spoken at the Whig Club of England, Dec. 41792 (London: James Ridgway, [1792]).

29. "Ridgway dines with Fox this day", in a "Report from spy Lynam: LCS General Committee (Government paraphrase), 10 January 1793," in Thrale, Selections, 43.

30. Royal Recollections went through eleven separate editions within the first year of sale and thirteen editions in total. 
In 1789, while still on good terms with Carlton House, Ridgway was careless - careless enough not to fully screen a publication to which he lent his name. ${ }^{31}$ Philip Withers had approached him with a request to lend his imprint to a pamphlet titled History of the Royal Malady to Which Is Added Strictures on the Declaration of Horne Tooke (1789). Generally sympathetic to the treatment of John Horne Tooke (a fellow member of the Revolution Society), it is not difficult to see why Ridgway acceded to the request, but apparently he did so without first reading the pamphlet. Unfortunately for him, it contained a claim that the Prince of Wales and Mrs. Fitzherbert were married, or soon to be so, at a time of acute political sensitivity when the question of the regency was being hotly debated. Ridgway's friendly connection with the Prince of Wales made this oversight particularly embarrassing. Soon after taking his supply of the pamphlet (and realizing his error), Ridgway contacted Withers and informed him that he could not put his name on the piece for fear of upsetting those for whom he had the "Highest Friendship and Respect." 32 At a meeting attended by Ridgway and Withers, emissaries of the Prince of Wales threatened the author with prosecution and immediate imprisonment if the pamphlet was sold anywhere, unless certain revisions were made. The whole incident was recounted in a follow-up pamphlet by Withers, Alfred or a Narrative of the Daring and Illegal Measures to Suppress a Pamphlet Intituled Strictures on the Declaration of Horne Tooke (1789), in which he acknowledged that Ridgway played no part in the composition of the former pamphlet, and indeed knew nothing of its contents. Such a declaration saved Ridgway from a prosecution instigated by Carlton House, but just to make sure, he never returned the pamphlets to Withers, who in turn accused Ridgway of acting as a de

31. Ridgway would have been painfully aware of the vulnerability of publisherbooksellers to political prosecutions. His former employer, John Almon, had taken a prominent part in the "Printers' Crisis" of March 1771, when his reporting of parliamentary proceedings was deemed a gross infraction of parliamentary privilege. While Almon's patron Lord Temple successfully protected him on that occasion, in 1786 he was forced to flee to France for publishing a government-planted libel. However, clearly Almon's assertion that publisher-booksellers did, "not have the time to read every publication," was a feature of the trade.

32. Philip Withers, Alfred or a Narrative of the Daring and Illegal Measures to Suppress a Pamphlet Intituled, Strictures on the Declaration of Horne Tooke, Esq., Respecting "Her Royal Highness the Princess of Wales," Commonly Called Mrs. Fitzherbert (London: for P. Withers, 1789), 33 . 


\section{Symonds and Ridgway's Conversion}

facto censor. Ridgway's swift actions to defend himself hint at the extent of his political allegiances and suggest a strong desire to maintain his valuable ties of patronage. Withers issued a writ against Ridgway for maintaining possession of the pamphlets that he had paid to be printed. The author not only hinted that Ridgway's actions were motivated by a desire not to offend his patron but went further, suggesting that he had been bribed: "it is absurd to imagine that a bookseller would venture to detain property, in violation of law, equity, and the practice of the trade, were he not well paid and well supported." ${ }^{33}$ Withers went on to comment sarcastically, "I dare not suppose that Mr. Ridgway is in habits of the sincerest friendship with the Prince of Wales, Mrs. Fitzherbert; and as I have mentioned, with Mr Fox, Burke, Sheridan and Lord North, I suppose they are his friendships, and to their protection I sincerely recommend him." ${ }^{34}$ Thus, in an ironic twist, Ridgway was accused of censoring the press, when there was, and would be, hardly a more outspoken advocate of the right of free expression in print. At this point, Ridgway's political colours were, it seems, nailed firmly to the mast in support of what Lessons would describe only a year later as a "needy and profligate cabal. ${ }^{35}$ Presumably, with the Regency Crisis at its height, everything was to be gained by a close alliance with the prince, but given Fox's subsequent mismanaging of the projected regency and the temporary remission of George III's mental instability, ${ }^{36}$ such a patron no longer held the same attraction, particularly since everybody's eyes were by 1792 firmly on events in France.

Whether or not Ridgway and Symonds did receive funds from supporters of Charles Fox in the late $178 \mathrm{os}$, as Almon had before him, is difficult to determine, but in any event the arrangement was short-lived. It is also difficult to say with certainty whether this reflects the confidence of maturing businessmen better able to support themselves through direct

33. Ibid., 40.

34. Ibid.

35. Lessons to a Young Prince, 2nd ed. (London: Symonds, 1790), 4. A phrase replacing, "but merely by the universal dread of the return of the coalition," p. 4 in the first edition.

36. Contemporary doctors had little success determining the cause of George III's instability. Porphyria was first suggested in Ida Macalpine and Richard Hunter's article, "The 'Insanity' of of King George III: A Classic Case of Porphyria," British Medical Journal 1, no. 5479 (8 January 1966): 65-71. Later studies have also found high levels of arsenic in samples of his hair. 
sales, or whether it marks a genuine movement in their political beliefs. In The Business of Books (2007) James Raven recognizes the difficulties involved in making such a determination between raw commercialism and benign altruism in the book trade, pointing out that "Regency and Victorian chroniclers of the book found it necessary to defend their heroes from charges of vulgar commercialism by illustrating their personal virtues, not their business operations. ${ }^{37} \mathrm{He}$ also notes booksellers were in the ideal position to "create a mythology — and a demonology — of their trade." 38 Profit motive was clearly a major impetus behind both Symonds and Ridgway's publishing activities, a fact reflected by their determined and sophisticated marketing of Lessons. ${ }^{39}$ A contemporary satirical pamphlet titled A Speech at the Whig Club; or a Great Statesman's own Exposition (1793), picked up on this very point, neatly encapsulating Ridgway's two publishing criteria: was it anti-government and proliberal, and would it sell? This hints at an awareness by contemporaries of his shift in emphasis towards non-party-based democratic reform. The pamphlet alleged that Ridgway had re-published and adulterated, without consent, the contents of a speech opposition leader Fox gave to the Whig Club on the 4 December 1792, which had first appeared in The Sun, advertising it for "two-pence." This sum induced the anonymous author of the satire to pen the following ironic lines:

What! All this speech for Two-pence? 'Tis portentous,

That such a Patriot Bookseller should mar things!

And is the greatest Statesman Heaven has sent us,

Thus hawk'd about the streets for twice four farthings?

This attack on Ridgway's mercenary motives, which it should be noted, also mocked Fox's credentials, continued:

Ridgway! Me thinks, for such a Sage Oration,

Extremely base and paltry such a Price is.

Poets are poor---yet gladly would I pay,

37. James Raven, The Business of Books, 212.

38. Ibid.

39. Levin has suggested that profit motive was the prime motivation behind Ridgway's publication of the Memoirs of Mrs. Billington (see below), stating, "One cynical reason [why he published them] is that he wanted to make money. Scandalous memoirs sold, and Ridgway published his share" (Susan Levin, "Vice, Ugly Vice: Memoirs of Mrs. Billington from Her Birth" in Eugene Stelzig, ed., Romantic Autobiography in England [Farnham: Ashgate Publishing Limited, 2009], 58). 


\section{Symonds and Ridgway's Conversion}

Twice two-pence and twice that for such a treat:

A dinner may be bought another day;

But such a speech as this we seldom meet. ${ }^{40}$

The reference to "Patriot bookseller" had a double meaning: it was both an allusion to the newspaper, The Patriot, of which he was co-proprietor, and a generic term of abuse used predominantly by country Tories to describe advocates of parliamentary reform. The satirist added in two footnotes that the retail price of the speech was twopence, yet the wholesale price was three halfpence, and more importantly, that "There appears to be something particularly apposite and becoming about the selection of this person, as the publisher of this speech" [emphasis mine] ${ }^{41}$ However, Ridgway's re-published version of the speech was not verbatim as he claimed, for he had inserted into the text a "toast" allegedly given by Fox on the occasion. This "toast" significantly altered the way the foregoing contents of his speech was likely to be read, making the line that Fox was apparently pursuing accord much better with his own principles. Naturally, readers seized upon this unauthorized addition, and an exchange of published letters ensued in various newspapers, reprints, and attachments to satires, in the hope that bringing them before the public would shed further light on the issue.

The exchanges began on the 10 December 1792 with a letter to the Morning Chronicle stating that Ridgway's published version of Mr. Fox's speech, "concerning the declaration of his principles, respecting the present crisis in public affairs, and a reform in the representation of the people, spoken at the Whig Club, Dec 4 1792," had "grossly misrepresented" what passed at that meeting. ${ }^{42}$ Far from "declaring his principles on a reform of parliament," he had uttered no opinion on the matter, though the letter added ambiguously "his sentiments remain the same as ever." 43 Similarly, the writer claimed that whereas Ridgway's pamphlet stated Mr. Fox had given a toast to "Equal liberty to all mankind," this was not true, and that no such toast had been given whilst either he, or the Duke of Portland, or any members of the society were in the room. ${ }^{44}$

40. A Speech at the Whig Club; or, a Great Statesman's Own Exposition of his Political Principles (London: Southern, [1793]), 1-2.

41. Ibid., 1.

42. Ibid., 21 .

43. Ibid. Interestingly, frustration at Fox's failure to declare for or against anything and to waste political advantage was one of the principle criticisms of him in Lessons. 44. Ibid. 
Since the publication of Thomas Paine's The Rights of Man less than a year earlier, such a call had taken on new significance. The toast had in fact been, "The cause of liberty all over the world," a standard toast used by Fox on many occasions in public. ${ }^{45}$ Clearly Ridgway reworked the text to align it more closely with his own liberal sentiments, demonstrating the level of his frustration with Fox's political impotence and equivocation. There had been no objection to the initial Morning Chronicle's report of the event by the Duke of Portland - the objections were solely to the additions in the pamphlet, which were "equally insidious in their tendency both to his Grace and Mr. Fox." ${ }^{46}$ Less than three years earlier in the Withers Case, Ridgway was prepared to seize papers on behalf of Carlton House; now his more liberal political convictions prompted him to let the pamphlet stand, as he explained in a curt response to his critics:

Sir,

When the character of an individual who aspires to the honest fame of Independence and Impartiality, has been unjustly attacked, it is a Duty which he owes to himself and society, to vindicate it from aspersion. As the editor of the Morning Chronicle has thought proper to state my Publication of Mr Fox's Speech as Insidious in its tendency to Mr. Fox, I beg the public to compare Mr. F.'s speech, as published by me, and also as published in the Morning Chronicle of the 4 th December, and they will find they literally and exactly agree. It will then remain on them to determine on whom the charge of insidiousness may be properly fixed - on one who was eager to announce the real and liberal sentiments of Mr. Fox, or him who now seeks, by a subsequent denial of the authenticity of the speech, and his own statement of it, in order to deprive Mr. Fox of that comportion of Public Favour to which his manly conduct has deservedly entitled him. ${ }^{47}$

The reply to this letter was swift and laced with irony. Ridgway had indeed "copied" the main text from the Morning Chronicle, a charitable act meant to benefit the nation by putting the speech into a format more durable than a newspaper. However, he had added a "toast" that Mr. Fox did not give, which the Morning Chronicle concluded was deliberately

45. Ibid.

46. Ibid.

47. The third edition of Ridgway's pamphlet, The Speech of the Right Hon. Charles James Fox (London: Ridgway, 1792), also repeated this item of correspondence, but with an additional paragraph which read, "Will any real friend of our Constitution deny, but that an equal representation of the People of England, is an Improvement of which our Constitution is susceptible, which all honest and enlightened men pant after, and which Mr. Fox must therefore have meant (or a thing impossible), could have meant nothing" (i). 
intended to compromise Mr. Fox and to subject the "Gentleman and his friend in insidious calumny." ${ }^{8}$ The editor of the Morning Chronicle hoped Ridgway, aware that he had been "imposed upon," might correct the pamphlet. ${ }^{49}$ But, the formerly "dutiful" Ridgway no longer held any qualms about offending such a Whig luminary as the Duke of Portland, and he was prepared to suffer the consequences.

In a list of the political affiliations of newspapers drawn up by a contemporary, John Williams, both the Morning Post and the Morning Chronicle were described as favoring Fox; yet as the above exchanges show, this did not mean that they represented the same political viewpoints, and many contemporaries argued the fractious nature of the opposition kept Pitt in power. This indicates that precise and personal loyalties were much more local than is often imagined, with infighting amongst rival factions. The case also suggests Ridgway no longer showed uncritical allegiance to Fox and Carlton House by 1792, and more broadly that classifying publishers in a polarized and static way is perhaps unhelpful when drawing conclusions about the dynamic and fast-changing ideological connections between patrons, publishers, and authors. Ridgway clearly attempted to place Fox in a position whereby the public appellation for his "toast" meant that he could not easily retract it, a clever piece of political maneuvering by an astute political operator showing the frustration of many at Fox's unwillingness to commit to principles of parliamentary reform supported by many within his own party. Despite this, a lingering suspicion remains that the Fox camp deliberately used Ridgway and his pamphlets to test the political temperature of various ideas: having assessed the response of voters and members of parliament, they could be either publically avowed or strenuously denied. Thus, whilst Ridgway's publications were staunchly anti-administration or anti-government, to call them simply "Whig party" productions or "opposition tracts" (a label applied to Lessons) is to misunderstand the political fractures within the Whig movement itself as well as the evolution of Ridgway's own politics; from a party-political standpoint, Lessons marks a crucial stage in this transformation.

Although nothing ultimately came of the Speech at the Whig Club incident, it signaled the start of a series of high-profile events involving both Ridgway and to a lesser degree Symonds. They no longer felt such

48. Speech at the Whig Club, 22.

49. Ibid., 26. 
a close affinity with Carlton House, and scarcely four years after Ridgway's confrontation with Withers, both were languishing in Newgate Prison for a series of political libels, not dissimilar to the kind that Ridgway had avoided through his political connections and "illegal measures" in the Withers case. He was sentenced on 8 May 1793, alongside his associate and friend Symonds, who was already serving two years imprisonment for selling the second part of Thomas Paine's Rights of Man. Both pleaded guilty by default - essentially no contest - to three counts of seditious libel, with Ridgway pleading mitigation for a lighter sentence. The attorney general accepted that "he had made every retribution in his power," especially by pleading guilty to the charges, thereby preventing a public trial, which was potentially a vehicle for disseminating the mischievous doctrines contained in the works. ${ }^{50}$ The attorney general further accepted that Ridgway had a wife and three children to support, that another publisher had already published The Rights of Man, and that he was not the author of any of the works for which he was being prosecuted. In a further effort to secure leniency, Ridgway's counsel offered to give up the name of the author of The Jockey Club in what would have amounted to a gross breach of radical solidarity. ${ }^{51}$ However, while accepting the mitigation, the attorney general found it "incumbent upon him to bring offenders to justice," and the corresponding judgment was severe. ${ }^{52}$ Ridgway was convicted of three counts of seditious libel for publication of The Jockey Club (a rather crude satire on the chief political personages of the day, notably including a chapter on the Prince of Wales), Paine's A Letter Addressed to the Addressers, and the second part of his The Rights of Man. His sentence was two years imprisonment for the first libel, a $£$ ioo fine and further year in prison for the second libel, and the same sentence for the third offense, totaling four years. In addition, he was bound over on a surety bond of $£_{5}$ oo for five years good behavior. Symonds, already in prison for selling the Rights of Man, was

50. Lloyd's Evening Post (1 May 1793).

51. Michael David, Iain McCalman, and Christina Parolin have argued that Charles Pigott's "anonymity on paper," left his publishers to their fate when prosecuted for seditious libel, which is no doubt why Ridgway offered to name the author of The Jockey Club as part of a plea bargain. The trial of Symonds and Ridgway shows that anonymity between author and publisher was nearly impossible, and that a publisher's knowledge of a writer's identity was a commodity that could be redeemed like anything else (Newgate in Revolution, 2).

52. Lloyd's Evening Post (1 May, 1793). 


\section{Symonds and Ridgway's Conversion}

given another term of one year and fined $£_{4} 400$ for $A$ Letter Addressed to the Addressers, and one year and $£ 100$ for his part in the publication of the Jockey Club. However, Symonds and Ridgway were not in Newgate alone; their prosecution formed part of a concerted campaign against booksellers and authors in the period following the French Revolution, designed to reign in the popular press and anti-government, democratic, "Jacobin sentiment."

Four years after Withers's charge that Ridgway was a "press censor" acting for the opposition, both he and his partner Symonds became martyrs for the cause of press freedom. Their fame as martyrs was long-lived..$^{53}$ Almost seventy years after his imprisonment, the Gentleman's Magazine mentioned that Ridgway had been a victim of Pitt's "Terror." ${ }^{44}$ In Justice to a Judge (1793), Ted Hughes used Symonds and Ridgway's pre-trial detention, apparently without bail, as an example of the illegal judicial suspension of the right of habeas corpus, "in defiance of the boasted liberality and justice of the maxim, which says, that our laws presume every man be innocent, till his guilt be made manifest." 55 To reinforce his point, Hughes cited, appositely, a lengthy passage from Lessons on the injustices inherent within the English legal system. The extract appeared from the second edition onwards and was one of the few contemporary citations of Lessons to focus on it and its author's portrayal of the judicial system. Approriately, it was Williams in particular who was quoted on matters of judicial integrity, in defense of his own publishers' right to equality of judgment:

Counsel are often in collusion with attornies, called pettifoggers; favour their prepared evidences, and abuse those who are unprepared, with a degree of profligate impudence and unprincipled villainy, which the judges should correct

53. The call for the independence of publisher-booksellers was made possible in part only because of the trade's profitability and the entrepreneurial acumen of its participants. Alternative sources of revenue replaced the notion of a single wealthy patron. More and more diverse revenue streams developed, which ranged from the emergence of publisher-authors, to literary extortion, receiving party money, holding large portfolios of publication rights to the works of the most well-known writers, current and past, and so on.

54. Gentleman's Magazine (February 1863): 243.

55. T. Hughes, Justice to a Judge, An Answer to the Judges Appeal to Justice, in Proof of the Blessings Enjoyed by British Subjects (London: Ridgway, 1793), 14. The suspension of the Act of Habeas Corpus (1679) formally passed through parliament on 7 May 1794. However, systematic violations of the act had been in effect commonplace since early 1792. 
with more determined severity; if they wish to preserve reverence for the laws, and respect for those who administer them. ${ }^{56}$

The case of the booksellers' imprisonment aroused such interest that the talented young engraver Richard Newton, at the behest of his patron William Holland, produced a two-foot etching titled "The Promenade in the State Side of Newgate" (1793) featuring twenty-two portraits of what was collectively dubbed the "Newgate Radicals." 57 The figures with an asterisk beside their names were merely "visitors," but those actually interned included Symonds and Ridgway. John Barell has argued the image helped codify a "group" of self-conscious radicals and shaped public opinion; in a very real sense, a new form of Jacobin-style radicalism required a new means of expression. These large and expensive prints were only produced in small numbers, thus well beyond the means of most members of the public towards whom they were nevertheless aimed. ${ }^{58}$ Booksellers had created a new and potent form of political expression-large prints displayed in book shop windows - which proved so effective that the adminstration regarded them as a "serious social and political problem - a great and public nuisance. ${ }^{.59}$ Barell contrasts these images with an earlier, equally important series of etchings:

These are not in the heroic vein appropriate to men facing transportation or a trial on a capital charge: as Ian McCalman has argued, these images depict 'British Jacobin civility, symbolically representing the fine manners and morals of radical philosophes under the most testing and uncivilized circumstances'. Soulagement is a variation of Hogarth's definitive image of impolite sociability, the drunken debauch. A Midnight Modern Conversation: the point is to show that the political prisoners caught up by Pitt's 'terror' exhibit the very opposite

56. Ibid. The extract appears on p. 96 of the second edition of Lessons. It should be noted, however, that this was published before their imprisonment and therefore could not have been written in response to it. There is no evidence that Williams ever visited Symonds or Ridgway in Newgate Prison, although they were held "stateside," and accordingly had generous visiting rights.

57. See Michael T. Davis's review of Richard Newton and English Caricature in the 1790s, in The Australian Journal of Politics and History 45 (1999): 132-134.

58. Barrel argues that at a half-guinea subscription, they were well out of reach for most people and were probably only produced for the relatives of the loved ones involved in the images. For a good account of the works of Richard Newton, see David Alexander, Richard Newton and English Caricature in the 1790s (Manchester: Manchester University Press, 1998).

59.John Barell,"Radicalism, Visual Culture, and Spectacle in the 179os,"Romanticism on the Net 46 (May 2007): 5, doi:10.7202/o16131ar. 


\section{Symonds and Ridgway's Conversion}

of the appallingly impolite behaviour of Hogarth's drunks. The Promenade derives from its own first version. ${ }^{60}$

Ridgway and Symonds widely and actively disseminated details of the case against them, in much the same way that John Almon earlier had documented his own trial before Lord Mansfield in The Trial of John Almon (1770) following his conviction for selling a reprint of Junius's Letter to the King. Whilst their actions did not shatter the mold of prison-dissident literature, the sheer breadth and intensity of the media they employed presented a considerable challenge to the suppression attempts of the ruling authorities. A brief account of their internment appeared in The Proceedings in Cases of High Treason, under a Special Commission of Oyer and Terminer (1794). ${ }^{61}$ However, they also found support for their cause amongst printers and publishers with whom they had little or no previous association; for example, The Chronologist of the Present War (1795), published by the small-scale printer J.W. Myers, presented their plight sympathetically. ${ }^{62}$

Both men served their full terms: the Morning Post and Fashionable World announced Ridgway's release on the 6 May 1797 with little ceremony; Symonds's release went unrecorded. While conditions in the prison were not terrible, rampant disease claimed the lives of several high-profile detainees and posed a constant threat. "Gaol fever," or typhus, became a political issue with which Symonds and Ridgway-ever willing to challenge the administration-became embroiled. ${ }^{63}$ The controversy ran for several months and centered on a report by Dr. Lettsom, who visited Newgate on 7 November 1793 investigating the deaths of Lord George Gordon and Thomas Townley Macan. His report was sup-

6o. Ibid., 28.

61. The Proceedings in Cases of High Treason, under a Special Commission of Oyer and Terminer, which was First Opened at Hicks's Hall, Oct. 2, 1794, and Afterwards Continued at the Sessions House, in the Old Bailey (London: J. Ridgway \& H.D. Symonds, 1794), 18.

62. The Chronologist of the Present War: Containing a faithful series of the events which have occurred in Europe, from the commencement of the year 1792, to the end of the year 1795 (London: J.W. Myers, 1795). Maxted records his first known imprint (1794), and his death on 6 August 180o. See "Exeter Working Papers in British Book Trade History," http://bookhistory.blogspot.com/2007/o1/london-1775-1800-m.html, accessed 21 April 2012.

63. For a first-hand account of life in prison during the 1790s, see "The Diary Thomas Lloyd Kept in Newgate Prison, 1794-96," Newgate in Revolution, 81-116. 
pressed and the fever's existence denied by the authorities. ${ }^{64}$ To Symonds and Ridgway, this represented a gross failure of government in its duty to ensure the welfare of prisoners and their visitors. On 16 November 1793, Ridgway and Symonds wrote to the Gazetteer and New Daily Advertiser testifying to the existence of the fever as diagnosed by Dr. Lettsom, who had attributed the death of Lord Gordon and Macan to "an infectious gaol fever, of the worst kind ... [in the] same class with Yellow Fever, and nearly related to it." ${ }^{65}$ Several months later, a fellow Newgate inmate, Thomas Lloyd, published a pamphlet Address to the Grand Juries of the City of London and County of Middlesex (1794), which mentioned both Ridgway and Symonds. In the pamphlet, Lloyd suggested that his poor treatment while in prison resulted from his refusal to bribe his jailor: "had I been content to pay the extortionate demands of a mercenary Jailer, as others were, he never would have removed me ONLY, for signing a certificate, in common with John Frost, James Ridgway, and Henry Delahay Symonds, respecting Dr. Lettsom's declaration of the existence of the Jail distemper, raging in this place, the later end of last October, and the beginning of November." 66 However, Symonds and Ridgway apparently suffered no long-term health problems from their imprisonment. They later published Dr. Lettsom's Hints Designed to Promote Beneficence, Temperance, and Medical Science (1797), which intriguingly reprinted in entirety David Williams's An Account of the Institution of the Society for the Establishment of a Literary Fund.

It is also clear from other testimony that, although they had no direct supervision of the technical aspects of the publications that were printed and distributed in their name during imprisonment, Symonds and Ridgway did still maintain some degree of control of their business affairs, such as taking possession of manuscripts and arranging for further publications. An 1851 article in Blackwood's Edinburgh Magazine described the case of the poet and politician Robert Southey, whose friend Robert Lovel visited Ridgway at Newgate and distinctly recalled the experience because he was "never on any other occasion within the

64. See for example Dr. Hudson's appeal not to be sent to Newgate prison as he was "given to understand (as he affirmed) on the authority of Dr. Lettsom, that a contagious distemper then raged within the prison," The World (4 November 1793).

65. Gazetteer and New Daily Advertiser (16 November 1793).

66. Thomas Lloyd, Address to The Grand Juries of the City of London and County of Middlesex (London, 1794), 2. 


\section{Symonds and Ridgway's Conversion}

walls of Newgate." ${ }^{\prime 7}$ Lovel bore the manuscript of a poem written by Southey whilst at Oxford, full of "young ardour for liberty and equality," for which he was seeking a publisher. ${ }^{68} \mathrm{An}$ extract in The Political Progress (1795) provides further evidence that Ridgway and Symonds continued publishing while in prison: "At London, a new edition was printed by Ridgway and Symonds, two booksellers, confined in Newgate, for publishing political writings. They sell the pamphlet and others of the same tendency, openly in prison." 69 In case a reader missed the point of the remarks, they continue "it is next to impossible for despotism to overwhelm the divine art Printing. ${ }^{.70}$ Their experiences in Newgate, the connections they made, and their now-personalized sense of injustice mark a turning point in their careers as well as the acceleration of a political transformation that had already begun before their confinement. Both men now seemed to have fully embraced the cause of radical reform. In 1794, a half-penny Conder token appeared with a picture of Newgate Prison on the obverse and the phrase "payable at the residence of Messrs. Symonds, Winterbotham, Ridgway \& Holt" on the reverse, a significant gesture since the very act of issuing a token represented a protest against royal power, which had long tried to legislate against the use of private tokens that had proliferated during the periodic times of coin shortage. ${ }^{71}$

67. Blackwood's Edinburgh Magazine 69, no. 426 (April 1851): 399.

68. Ibid., 398 .

69. James T. Callender, The Political Progress of Great Britain: or, An Impartial History of Abuses in the Government of the British Empire, in Europe, Asia, and America, 3rd ed. (Philadelphia: R. Folwell, 1795).

7o. Ibid.

71. The Crown had not minted new copper coin since 1775, leading to an acute shortage of small coin, especially in the provinces. Though never legal tender, in response to this lack, businesses began issuing their own tokens, redeemable at their outlets. The final decade of the eighteenth century saw a huge proliferation of such tokens, which were also used for advertising, and unlike their seventeenth-century equivalents, conveyed political messages. In 1797, the use of tokens was made expressly illegal to support the issuance of new coinage. Although issued before the express prohibition of token usage, Symonds and Ridgway's decision to issue a token represented a firm statement against the Crown prerogative of minting coinage. W. Longman in his work on eighteenth-century tokens suggests that William Sherwood, who was at this time only seventeen years old and apprenticed to Symonds was, "largely responsible for carrying on the business when Symonds was sent to prison," Tokens of the Eighteenth Century, Connected with Booksellers $E^{2}$ Book Makers (London: Longmans, Green \& Company, 1916), 43-44. 
Symonds and Ridgway's incarceration also settles the lingering question of Williams's authorship of Lessons. Booksellers often advertised new titles or editions by including a list of them as back matter in the books they vended, and Lessons had always appeared as anonymously authored or by the pseudonymous "Old Statesman." However, the list of new publications attached to a piece of prison literature they issued in 1793 included an entry for "Lessons to a Young Prince by the Rev. David Williams, Sixth Edition enlarged." ${ }^{2}$ Extant copies of the first American and sixth English editions continued to bear the pseudonym on their title pages "Old Statesman," and so this must surely have been an oversight, especially since it contravened the explicit statement at the beginning of Lessons that the printer and publisher were unaware of the author's identity (and, as contemporaries argued, that a "price" on anonymity had likely been settled on). Such a slip can only be explained by the fact that the interned Symonds and Ridgway did not have direct supervision of their businesses, underscored by the running title on the same page that read "First Year of [their] Imprisonment at Newgate." 73 Ralph Manogue supports the conclusion that their time in Newgate was the catalyst for their further radicalization. Always advocates of a free press, and inclined to liberal opinions, it was in prison that Ridgway and Symonds "connected with all the leading radical bookseller-publishers and major reform societies of the day." ${ }^{4}$ The argument advanced by McCalman that imprisonment in fact had a positive effect on their businesses is underscored by a slew of publications produced in various partnerships with other incarcerated publisher-booksellers and writerinmates, including Daniel Holt, William Winterbotham, John Thelwall and Horne Tooke.

72. Henry Yorke, These are the Times that Try Men's Souls! (London: Ridgway \& Symonds, 1793).

73. A "person in an official situation" who, perhaps considering it provocative, wrote to the Morning Post, noticed this running title. Ridgway and Symonds were requested to explain the meaning of this statement, and their reply is quoted by the letter writer: "Because we wish to call the attention of the Public to our Advertisement, and we mention the fact to caution others against falling into a similar predicament." This did not convince the "person in an official situation," who saw it as an opportunistic attempt by the "Newgate publishers" to bring their plight and situation to the attention of the newly formed cabinet, "it was not however, to consider of the circumstance, that the Cabinet Council was assembled" (Morning Post [12 June 1793]).

74. Manogue, “The Plight of James Ridgway," 158. 


\section{Symonds and Ridgway's Conversion}

Symonds and Ridgway's imprisonment in 1791 and 1793 indicates that, above and beyond the profit motive, their political beliefs were largely in accord with the views of the radical authors they chose to publish. In the absence of detailed financial records for the period, it is difficult to determine whether their businesses flourished during incarceration (evidenced by the marked increase in output, as Michael Davis and others suggest), or whether imprisonment had a negative impact on their establishments (as both Ridgway and Symonds claimed) ${ }^{75}$ On the one hand, imprisonment provided rich and fertile ground for recruiting authors and obtaining material relating to state prosecutions, which was very much in demand, and it fostered what McCalman has called "a forum for political expression and cultural resistance." On the other hand, day-to-day superintendence of their businesses was impossible, and this, coupled with the expenses of the trials and maintenance in prison, resulted in the accumulation of large debts. ${ }^{76}$ On 3 January 1795 , Symonds, Ridgway, and Holt drafted a letter intended for "general circulation," that supports the latter view. It appealed for financial assistance to alleviate their suffering, detailed their crippling expenses, and outlined the effect imprisonment was having on their businesses, complaining of "daily feeling the severe and calamitous pressure of a long, distant and ruinous separation from our business, our families, and our friends at large." 77 The letter illustrates the fraternal bond forged between the three publishers, dating the letter "our second year of imprisonment." It intimates that the publishers considered their imprisonment a hazard of their occupation, appeals for benevolence on the basis of no criminal intent, and claims it was unfair that their families should be left destitute for whatever misdemeanors they may have performed. Most tellingly, it

75. See George Dyer, A Dissertation on the Theory and Practice of Benevolence (London: Kearsley, 1795), 87-90.

76. McCalman et al., Nervgate in Revolution, xi.

77. McCalman emphasizes the positive side of the Newgate experience as a catalyst for a number of publications. However, their imprisonment did prevent them publishing works, whether because of accessibility issues or because of the stigma. Samuel Taylor Coleridge offers one such example: "It was the zealous Wade who, with the help of Robert Allen, Coleridge's schoolfellow, took over the London arrangements for advertisements and for finding a publisher. Coleridge had wanted Ridgway, but in the end Parson's was engaged," and the accompanying note, "James Ridgway was still in Newgate Prison, serving a four-year sentence" (Lewis Patton, introduction, The Collected Works of Samuel Taylor Coleridge: The Watchman [London: Routledge \& Kegan Paul, 1970], xxxiv-xxxv). 
affirms that they believed they were "suffering in a public cause." 78 The publishers said the initial experience had cost them $£_{1}, 700$, and after their full terms had been served, an aggregate of $£_{3}, 800$ each, especially punishing since they had "now in some measure suspended" their businesses. ${ }^{79}$ George Dyer, who reproduced this letter in his Dissertation on the Theory and Practice of Benevolence (1795), also argued that Ridgway's was an especially acute case, hinting at the same time that the letter had been suppressed, only reaching John Cartwright, a naval officer and campaigner for parliamentary reform. Whilst conceding that the connection between imprisonment and political martyrdom might in some cases "raise the reputation and extend the profits of a bookseller," this was not the case with Ridgway, his situation "singularly hard" and meriting "distinct consideration." ${ }^{0}$

Either way, their activity during imprisonment agrees with Burrow and Barker's study of late eighteenth-century publishers, in which they argue that the risks for publishers were great indeed, and that "dedication to publishing in such circumstances often required considerable prudence, occasional courage, and ideological commitment." ${ }^{11}$ It is inconceivable that either man was unaware of the risks that attended the selling or publication of the works for which they were convicted. Yet Symonds and Ridgway's convictions underpinned their advocacy of a free press, a cause that resonated deeply — and connected them firmly but not identically - with Williams, who also advocated press reforms and the protection of intellectual liberty. The author-publisher relationship, though complex, is almost always brokered by mutual advantage, a contract that assumes publishers carefully selected their authors and authors, once established, chose their publishers. James Dybikowski notes that Williams's interest was not so much in freeing an already "half-free" press from censorship but in preventing its corruption by the use of government and party funds - theoretical freedom from political culture, not literal freedom from litigation and judicial harassment. He held deep-seated reservations about the effect of unrestrained freedom of speech in which there was little defense against real libel. What Wil-

78. Dyer, Dissertation on Benevolence, 88.

79. Ibid.

80. Ibid., 96. It appears that the letter was never circulated.

81. Hannah Barker and Simon Burrows, Press, Politics, and the Public Sphere in Europe and North America 1760-1820 (Cambridge: Cambridge University Press, 2002), 15. 


\section{Symonds and Ridgway's Conversion}

liams advocated was "truth" as a defense against the charge of libel, as well as more robust mechanisms to deal with genuine cases of libel when they arose. Dybikowski argues that "Williams never believed that an unencumbered intellectual liberty implied the absence of protection for those libeled. As matters stood however, defenses against libel were weak." ${ }^{82}$

In many ways the activities of Symonds and Ridgway - mercantile and opportunistic, often insensitive and abandoned, but based on broad ideological allegiances and increasingly fiercely defensive of their right to print and distribute works freely-encapsulated the dilemma that Williams wrestled with for most of his life: how to maintain a completely unfettered press whilst protecting individuals from libels. ${ }^{83}$ For Williams, it was sometimes hard to distinguish the tyranny of booksellers and publishers from the oppressive and despotic actions of government. It was on this very point that Symonds and Ridgway's opinions diverged with those of Williams, leading to vastly different interpretations of the Glorious Revolution of 1688 . For the publisher-booksellers, more in line with the Whig Tradition, it was the Glorious Revolution that ushered in a period of press freedom, when the lapse of the Licensing Act in 1695 meant publications no longer required registration and licensing at Stationers' Hall prior to their distribution within the realm. For Williams, this absence of licensing requirements led to licentiousness within the book trade and the general mediocrity of literature. One of Ridgway's own stable writers, John Williams (alias Anthony Pasquin), offered a more extreme view of the power afforded booksellers as a result of relaxation of censorship. He claimed that booksellers held the literati in chains and urged them to disregard the impact their writing had on the personal reputations that many of their works attempted to destroy - all in pursuit of profit. Ridgway was by no means innocent of such venal behavior. For example, on 7 January 1792, The Times reported that the famed actress Mrs. Elizabeth Billington had served a bill of indictment before a grand jury against Ridgway for writing what were termed "extortionary letters" on the "subject of suppressing certain memoirs of the Lady, intended for publication. ${ }^{\prime 84}$ In this case, it was not a matter of libel but

82. James Dybikowski, On Burning Ground: the Life of David Williams (Oxford: Voltaire Foundation, 2006), 231.

83. For an extended discussion of Williams's views on the freedom of the press, see Dybikowski, On Burning Ground, 231-234.

84. The Times (7 January 1792). 
publishing ethics; whether the publisher had the right to print the letters against the wishes of their author. Ultimately the case was thrown out, but it highlights the aggressive practices of many of the leading booksellers ${ }^{85}$ Ridgway went ahead and published; the title page of Memoirs of Mrs. Billington (1792) declared that it reproduced several original letters "now in the possession of the publisher." ${ }^{66}$ The work caused such a stir that contemporary Franz Joseph Haydn noted in his diary, "you couldn't get a single copy after 3 o'clock in the afternoon." ${ }^{87}$ At first the production of this scandalous, pornographic material appears at-odds with his output as a radical publisher, leading one contemporary to describe him as a "scribbling pamphleteer, a griping bookseller" and an "obscure vendor of Grub Street pamphlets." ${ }^{88}$ However, as Levin argues, Ridgway's works invariably focused on important public figures, and detailing the affairs of performers, musicians, artists, and elite political figures was an eighteenth-century commonplace. ${ }^{89}$ Pioneering research by Robert Darnton and Lynn Hunt has shown that what at first glance we see as unself-consciously salacious behavior is the result of our projecting modern conceptions of pornography onto a pre-pornographic literaryscape (pornography only emerged as a distinctly self-conscious genre in France at the beginning of the nineteenth century - and slightly later in England, when it solidified in the context of mid-nineteenth century moralizing)..$^{90}$ Both scholars show how readers in the late eighteenth century consumed illicit material without the stigmatization that accompanied its emergence as a "category of thinking," and which later

85. For a brief account of the life of Billington, see Rachel E. Cowgill, "Billington, Elizabeth (1765-1818)," ODNB, doi:10.1093/ref:odnb/2397.

86. Memoirs of Mrs. Billington, from Her Birth: Containing a Variety of Matter, Ludicrous, Theatrical, Musical, and ..... with Copies of Several Original Letters, Now in the Possession of the Publisher, written by Mrs. Billington, to Her Mother, the Late Mrs. Weichsel: a Dedication; and a Prefatory Address (London: James Ridgway, 1792).

87. Howard C.R. Landon, ed., The Collected Correspondence and London Notebooks of Joseph Haydn (London: Barrie \& Rockliff, 1959), 255.

88. An Answer to the Memoirs of Mrs. Billington. With the Life and Adventures of Richard Daly, Esq. and an Account of the Present State of the Irish Theatre. Written by a Gentleman, Well Acquainted with Several Curious Anecdotes of All Parties (London: for the author, 1792), 1-2.

89. Levin, "Vice, Ugly Vice," 59.

90. See Robert Darnton, The Forbidden Best-Sellers of Pre-Revolutionary France (New York: Norton, 1996); and Lynn Hunt, ed., The Invention of Pornography: Obscenity and the Origins of Modernity, 1500-1800 (New York: Zone Books, 1993), 9-48. 


\section{Symonds and Ridgway's Conversion}

became a symbol of moral corruption and deviancy. ${ }^{91}$ Furthermore, representation of sexual activity, whether visual or textual, had a long tradition as a form of political humiliation and cultural resistance, embodied by the numerous tales (and engravings) of "pious" priests defrocked and lords caught rutting with their maidservants. As Hunt writes perceptively, "[pornography] was linked to free-thinking and heresy, to science and natural philosophy, and to attacks on absolutist political authority."92 In England, much like in pre-Revolutionary France, the distinction between different forms of "suppressed" books was conspicuously absent, suggesting that non-conformity might be interchangeably of a political, religious, or sexual nature.

Despite being aware of "what a valuable traffic is SCANDAL!", Ridgway protested in his "Prefatory Address" to the Memoirs that his motivation for publishing them was morally justified: he was only responding to the legal and personal threats made against him by agents acting for the Billingtons; and he felt compelled to show the virtues of a good life through the public "reprobation of a wretch, who has been the sole cause of alienating, an indulgent husband from an amiable and virtuous wife. ${ }^{{ }^{3} 3}$ Ridgway's only ethical concern about the letters was to establish their authenticity, for he had "some credit at stake with the public, and did not want to be informed, what construction that Public would put upon [his] conduct." ${ }^{94}$

Drawing together the implications of the three legal disputes discussed in this article, coupled with Ridgway's tampering with the Whig Club Speech, we can now more clearly discern the long-term and decisive shift by Symonds and Ridgway - the later perhaps more visiblytowards publishing independence and involvement with a burgeoning radical press, in the process casting off the Whig patronage and ideological identifications of the formative period of their businesses. We can also see that their migration toward independence of publication, advocacy of parliamentary reform, and championing of a free press predated their incarceration in Newgate prison, an event which nonetheless accelerated the process by giving them direct contact with a number of leading radicals. Clearly, contemporary judgments of Ridgway as a

91. Hunt, Invention of Pornography, 11.

92. Ibid.

93. Memoirs of Mrs. Billington, xv.

94. Ibid., iv-v. 
Whig stooge during the period 1788-1793 have no real purchase, and the notion that publishers remained ideologically and politically static is simplistic at best. While a significant amount of research remains to be done in order to fill in the many gaps in the personal lives and business activities of publisher-booksellers like Symonds and Ridgway, this article represents a significant step in what is likely to be a long, but highly rewarding process. 


\title{
BIBLIOGRAPHICAL NOTES
}

\section{Caxton's Death-Bed Prayers in Manuscript and Print}

\author{
A. S. G. EDWARDS
}

$\mathrm{T}$

He SINGLE SHEet BROADside known as Death-Bed Prayers was published by William Caxton in his Type $4^{*}$, ca. $1484 ;^{1}$ the only known copy is in the John Rylands Library of the University of Manchester. This work comprises two Middle English prose prayers, the first beginning "O Glorious Ihesu. O mekest Ihesu. O mooste swettest Ihesu I praye the that I may haue trewe confession contricion and satisfaction," the second "O The moost swettest spouse of my soule Cryste Ihesu desyryng hertely euermore for to be with the in mynde and wyll."2

These prayers seem to have attracted little commentary, although recently they have been identified as "the first work of Catholic spirituality printed in the English language." ${ }^{3}$ After first being produced by Caxton

1. STC 14554; Duff 112. For Caxton's types see William Blades, The Biography and Typography of William Caxton, England's First Printer (London: Trübner, 1882), 115-18.

2. These are represented collectively as no. 488 in N. F. Blake, R. E. Lewis, and A. S. G. Edwards, An Index of Printed Middle English Prose (New York: Garland, 1985); no manuscript copies of these prayers are recorded there.

3. John Saward, John Morrill, and Michael Tomko, eds., Firmly I Believe and Truly: The Spiritual Tradition of Catholic England (Oxford: Oxford University Press, 2011), 11. For brief discussion of these prayers see E. G. Duff, "English Fifteenth-

A. S. G. Edwards (University of Kent, Canterbury, Kent, UK, $\mathrm{CT}_{2}{ }_{7} \mathrm{NX}$ ) is Professor of Medieval Manuscript Studies in the School of English. He has recently edited (with Julia Boffey) A Companion to Fifteenth Century Poetry (Cambridge: Boydell \& Brewer, 2013) and published Nicolas Barker at Eighty. A List of His Publications to Mark His 8oth Birthday (New Castle, DE: Oak Knoll, 2013). He is currently engaged in studies of attribution in Middle English verse and of the trade in Middle English manuscripts in the nineteenth and twentieth centuries and he is a William H. Helfand Fellow at the Grolier Club. 
they enjoyed a quite extensive subsequent printed tradition and were incorporated into numerous books of hours by printers in England, including Caxton's immediate successors Richard Pynson ${ }^{4}$ and Wynkyn de Worde, ${ }^{5}$ and on the Continent for the English market, from the late fifteenth century onwards, down to at least $1531 .^{6}$

While the appearances of these prayers in printed form can be readily documented, it does not seem to have been observed that they also enjoyed a quite extensive manuscript tradition. In 1984, Ralph Hanna identified two copies in manuscripts in the Huntington Library, where they appear added at the end of a processional written in England in the early sixteenth century, and also in an early sixteenth-century Sarum Hours, written in Flanders for the English market. ${ }^{7}$ Hanna also drew attention to other manuscripts containing these prayers in Westminster Abbey ${ }^{8}$ and Magdalene College, Cambridge. ${ }^{9}$ These are both English collections of devotional materials of the late fifteenth or early sixteenth centuries.

Century Broadsides," Transactions of the Bibliographical Society, 9 (1906-08): 222-23; and George Painter, William Caxton (London: Chatto \& Windus, 1976), $156-57$.

4. Pynson's Hore intemerate beatissime virginis Marie (London, 1497 ), $\mathrm{G} 6^{\mathrm{r}}-\mathrm{G} 7^{\mathrm{r}}$ (STC 15886) is the only surviving incunable printing in England apart from Caxton's original. However, a number of early English printed books of hours survive only in fragments: for example, STC 15873.5, 15874, 15875, 15876, 15878, 15882, 15891 , 15893,15894 , and 15895 , so more early printed versions of these prayers by English printers likely once existed.

5. The earliest edition of de Worde's in which they appear is Hore beate Marie virginis secundum vsum insignis ecclesie Sarum totaliter ad longum \& sine require (London, $\left.{ }_{1503}\right), \mathrm{G}_{4}{ }^{\mathrm{r}}-\mathrm{G}_{5}^{\mathrm{r}}$ (STC ${ }_{15899)}$.

6. This Prymer of Salysbury Vse (Paris, 1531), fol. 1xxij ${ }^{\mathrm{r}-\mathrm{v}}$ (STC 15973).

7. MS EL. 34 B 7, fol. 82 $2^{\mathrm{v}}$; HM 1344, fol. $104^{\mathrm{r}-\mathrm{v}}$. See Ralph Hanna, The Index of Middle English Prose, Handlist I: A Handlist of Manuscripts Containing Middle English Prose in the Henry E. Huntington Library (Cambridge: Brewer, 1984), 39. The claim made there that these prayers occur in York Minster XVI. G. 5 is incorrect; this MS is unrecorded in O. S. Pickering \& Susan Powell, The Index of Middle English Prose, Handlist VI: A Handlist of Manuscripts Containing Middle English Prose in Yorkshire Libraries and Archives (Cambridge: Brewer, 1989).

8. MS 39, fols 83-86. On the Westminster manuscript see N. R. Ker, Medieval Manuscripts in British Libraries I: London (Oxford: Clarendon, 1969), 414; Hanna gives different foliation; it contains the arms of Henry VII's mother, Margaret Beaufort.

9. MS F. 4. ${ }_{13}$, fols $41^{\mathrm{v}}-42^{\mathrm{r}}$. On the Magdalene manuscript see M. R. James, $A$ Descriptive Catalogue of the Manuscripts in the College Library of Magdalene College Cambridge (Cambridge: Cambridge University Press, 1909), 24-37, esp. 24 and 29, where it is described as "beautifully written by or for Jasper Fyloll then apparently at Syon monastery." It is dated to " 1518 " by James. 


\section{Caxton's "Death-Bed Prayers"}

Other manuscript copies of these prayers have since come to light. An incomplete version has been identified in a fifteenth-century English manuscript containing verse and prose in Middle English, Latin, and French. ${ }^{10}$ And yet another copy has been published, but not identified, found in a manuscript in the Reed Collection, at the Dunedin Public Library in New Zealand: the Mantell Hours, an illuminated fifteenthcentury Sarum Hours made in Flanders for the English market. ${ }^{11}$

A further copy, again in an illuminated Sarum Hours, is in a manuscript in the Kent State University Library Department of Special Collections and Archives. This is a small ( $99 \times 68 \mathrm{~mm}$ ) hours, made probably in Flanders for export, with no shelf mark. ${ }^{12}$ It seems to date from the later fifteenth century or early sixteenth century if the hand provides a reliable guide. It includes on fols. [12]-[13] (the manuscript is unfoliated) these two Middle English prayers, preceded by two Latin prayers on fols. $[10]^{\mathrm{v}}-[12]^{\mathrm{v}} .^{13}$

There are few distinctive orthographic features in the Caxton DeathBed Prayers. The chief of these are they for thy $(4,6)$, abowe for above (27), as well as aboue (28), hawe for hav' (40) and the substitution of consonantal $u$ for $w$ elsewhere: treue (2, 7), uelcum (15), suettyst (18), and occasionally vice versa lowyt (28). It is entirely possible that these variants are without dialectal significance and are simply mistranscriptions. This

10. Paris, Bibliothèque Mazarine 514, fol. 147\% . See James Simpson, The Index of Middle English Prose, Handlist VII: A Handlist of Manuscripts Containing Middle English Prose in Parisian Libraries (Cambridge: Brewer, 1989), 19-20; and Alexandra Barratt, "Two Middle English Lyrics in the Bibliotheque Mazarine," Notes \& Queries, n.s. 31 (1984), 24-7.

11. MS 10, fols. $44^{\mathrm{r}-\mathrm{v}}$. The texts of these prayers are printed in Greg Waite, "Middle English Prayers and a Charm in a Dunedin Manuscript," World and Stage: Essays for Colin Gibson, ed. Greg Waite, Jocelyn Harris, Heather Murray, and John Hale (Dunedin: University of Otago, 1998), 93-108, esp. 97-99.

12. I am much indebted to Kent State University Library, and especially to Kathleen Medicus, Department of Special Collections and Archives, Libraries and Media Services, for permitting me to examine this manuscript, making available digital scans of the relevant leaves, and answering a number of questions.

13. The incipits to these prayers read respectively "O bone ihesu o dulcis o Ihesu fili marie uirginis" (fol. $11^{\mathrm{r}-\mathrm{v}}$ ) and "O bone Ihesu miserere mei dum tempus est miserendi" (fol. $\left.1 \mathrm{v}^{v}\right)$. Prayers with the same incipits occur in close proximity to the versions of the two Middle English prayers in Huntington Library HM 1344; see the description of this manuscript in Consuelo W. Dutschke, Guide to the Medieval and Renaissance Manuscripts in the Huntington Library, 2 vols. (San Marino, CA: Huntington Library, 1989), 2:573. 
probability is strengthened by a number of other clear mistranscriptions: an for and (12), crey for cry (16), erly for erply (20), synnyer for sinner (24), pleneuously for plenteuously (35).

It is rarely possible to distinguish confidently between careless and faithful copying of an eccentric exemplar. The Kent State manuscript, like the Huntington and Dunedin copies, was evidently copied on the Continent. The errors it contains may simply be the result of the unfamiliarity of a foreign scribe with English forms and script. Equally possible is that the errors of copying in the Kent State manuscript were caused by the prayers having been copied from a printed edition done on the Continent for the English market by compositors with an uncertain grasp of English. ${ }^{14}$ (These possibilities are not mutually exclusive.) Fourteen incunable editions of Sarum Hours are recorded as printed on the Continent, one in Antwerp by Gerard Leeu, one in Rouen by Martin Morin, and, with considerable frequency, in Paris, with five editions each by Philippe Pigouchet and Jean Jehannot, one by Jean Phillippe, and one by an unidentified printer; ${ }^{15} \mathrm{I}$ have identified these English prayers in six of these editions. ${ }^{16}$ The other editions are either fragmentary or do not contain the prayers (or both). The orthography in these editions does not correspond to that in the Kent State manuscript.

Nevertheless, all the manuscript copies of the Death-Bed Prayers are late and seem likely to post-date Caxton's edition and/or at least a number of the subsequent printed editions that incorporated these prayers. The variants from Caxton's text in the Kent State manuscript noted below are not sufficiently significant (they are mainly omissions) as to establish any textual relationship between the manuscript and printed forms of the text. But it seems possible that the Kent State version and some or all of the other manuscripts noted above could be added to the growing record of manuscripts copied from printed books in the later

14. See, for example, Curt F. Bühler, "'At thy golg first eut of the hous vlysse the saynge thus," Studies in the Renaissance 6 (1959): 223-35, on what he terms "the peculiar English ... in glancing over the foreign horae one is constantly struck by such truly astounding orthography" (223).

15. Leeu: STC 15873; Morin: STC 15877; Pigouchet: STC 15879, 15880, 15883, 15887, 15889; Jehannot: STC 15881, 15881.3, 15888, 15890, 15895.5; Phillippe: STC 15885; unknown: STC 15892.

16. STC ${ }_{15} 880, \mathrm{hr}^{\mathrm{r}}-2^{\mathrm{v}}$; STC $15885, \mathrm{i}^{\mathrm{v}}-5^{\mathrm{r}}$; STC ${ }_{15} 887$, i $^{\mathrm{r}}-7^{\mathrm{r}} ; \mathrm{STC}_{15} 888, \mathrm{I}_{3}^{\mathrm{v}}-5^{\mathrm{r}}$; STC ${ }_{15889}, \mathrm{H}_{7}{ }^{\mathrm{r}}-8^{\mathrm{r}}$; and $\mathrm{STC}{ }_{15890}, \mathrm{i}_{4}{ }^{\mathrm{r}}-5^{\mathrm{r}}$. 
Middle Ages in England. ${ }^{17}$

It is, of course, possible that more manuscript copies of the Death-Bed Prayers will come to light. But it is already clear that its brevity and subject matter made it a useful filler both in English printed and manuscript books of hours and in late devotional manuscript collections. Caxton's printing seems to have been the earliest surviving form in which these prayers circulated. Its surprisingly extensive afterlife in both manuscript and print seems worth a fuller appreciation than it has received.

I offer below a transcription of the Kent State version of the prayers. Transcription is literatim, and no effort has been made to correct apparent errors in view of their possible evidential value as discussed above. Contractions have been silently expanded, the Middle English graph thorn (p) and original capitalization have been retained; lineation has been added; punctuation has not been added:

[fol. $12^{\mathrm{r}}$ ] O glorious Ihesu $\mathrm{O}$ mekeste Ihesu $\mathrm{O}$ most swettest Ihesu I pray the that y may haue treue confession contrycion and satisfaccion or y deye and pat $y$ may see and receyue they holy body god and man sauyour of al mankynde Criste Ihesu without synne and pat pou wylte my lorde God forgyue me al my synnes for they glorious wondes and passion and pat [fol. $\left.12^{\mathrm{v}}\right]$ y may ende my lyfe in pe treue faype of holy chirche and parfyte loue and charite with myne euyn cristen as thy creature And y commande my soule into thy holy handys thrugh pe glorious helpe of thy blessyd modyr of mercy our lady saynt Mary and al the holy company of heuen An pe holy body of Criste Ihesu be my saluacyon of body and soule The gloryous blode of Criste Ihesu brynge my soule and body into euyrlastyng blysse and y cry God mercy y cry God mercy y cry God mercy welcum my maker uelcum my redemer uelcum my sauyour y crey pe mercy with herte contrite of my grete onkyndnys pat y haue hadde to pe [fol. $\left.13^{\mathrm{r}}\right] \mathrm{O}$ the most suettyst spouse of my soule Criste

17. On such manuscripts in general see J. K. Moore, Primary Materials Relating to Copy and Print in English Books of the Sixteenth and Seventeenth Centuries, Oxford Bibliographical Society Occasional Publication 24 (Oxford: Bodleian Library, 1992), esp. 1-10. On manuscripts copied from Caxton's editions see N. F. Blake, "Manuscript to Print," in J. Griffiths and D. Pearsall, eds., Book Production and Publishing in Britain, 1375-1475 (Cambridge: Cambridge University Press, 1989), 40332; see esp. 409-425, Appendix A: "Caxton prints for which a copy text survives or which were used as a copy," a useful work in urgent need of revision. 
96 Bibliographical Society of America

Ihesu desyryng hertylly euyr more for to be with pe in mynde and wylle and to lette none erly thinge to ly so ney

my herte as pou Criste Ihesu and y dred not for to dey

for to goo to pe Criste Ihesu and pat y may euyr more say

to pe with a glade chere my lorde my God my suffrayne sauyour Criste Ihesu I beseche pe hertly take me synnyer onto pi

grete mercy and grace for y loue pe with al my herte with al

my mynde and with al my myzte And nothyng so moche in erthe

ne abowe erthe as y do pe my swete lorde Ihesu Criste and

for pat y haue not lowyt pe and worschypyt the aboue al thyng as my lorede my god and my sauyour Crist Ihesu y beseche pe

with mekenys [fol. $\left.13^{\mathrm{v}}\right]$ and herte contrite of mercy and forgyuenesse 30 of my grete vnkyndenes for pe grete loue pat pou schewdest for me and alle mankynde what tyme pu offeredest thi glorious bodi

God and man vnto pe crosse per to be crucified and wounded and onto pe herte a scharpe spere there rennyng out

pleneuously blode and watyr for pe redempcioun and saluacyoun of 35

al mankynde and thus hauyng remebraunce stedfastly

in my herte of pe my saueour Crist Ihesu I dowte not but

pou wylte be ful nighe me and comforte me bothe bodely and gostly

with thy glorious presens and at pe laste brynge me vnto

thyne euerlastyng blysse pe whiche neuer schall hawe ende Amen

Variants Between Kent State MS. and Caxton's Edition (C):

7.om.] C alle

8. om.] C in; myne] $\mathrm{C}$ my

9. commande] $\mathrm{C}$ commende

11. om.] C Amen

12. An the] $\mathrm{C}$ The; brynge] $\mathrm{C}$ be

13. om.] C Amen; om.] $\mathrm{C}$ and

14. om.] $\mathrm{C}$ the; and] $\mathrm{C}$ Amen

15. om.] $\mathrm{C}$ haue

2o. erly] C erthely; to lye] $\mathrm{C}$ be

21. my] $\mathrm{C}$ myn; om.] $\mathrm{C}$ that

22. om.] $\mathrm{C}$ vn

27. ne] C nor; Ihesu Criste] C Cryst Ihesu

34. om.] C glorious

35. om.] C me

36. om.] $\mathrm{C}$ and

40. thyne] $\mathrm{C}$ thy 


\title{
Stemmata for Shakespeare Texts: A Suggested New Form
}

\author{
Pervez Rizvi
}

$\mathrm{T}$ EXTUAL ANALYSES of Shakespeare's works often contain stemmata that tell in a visual way the sometimes complicated stories of their transmission. This practice offers more than just the incidental benefit of representing in a picture the thousand words a scholar may spend on description. It offers a substantive benefit too. As is well understood, diagrams do not merely illustrate thoughts in symbolic representations, they also elicit new thoughts by invoking our minds' facility with visual patterns.

Shakespearean scholarship adopted its techniques for the visual presentation of textual relationships, including the form in which stemmata are drawn, from those developed by nineteenth-century scholars for the study of classical and biblical texts. In this note, I do not mean to question in any way the forms employed in classical and biblical scholarship. But I'd rather like to suggest that stemmata for Shakespeare texts could be constructed in a different, clearer fashion. I do this by presenting a small number of examples from current Shakespeare scholarship and arguing that, at best, they miss the opportunity to convey information more usefully, and, at worst, they inadvertently risk confusing the reader. ${ }^{1}$ I conclude by suggesting a new design for early modern textual

1.The aim of this note is solely to recommend to readers a better form; I am not arguing for or against the content of the stemmata I use as examples. Moreover, nothing in this should be taken as a criticism of the scholars whose stemmata I have chosen as my examples, since they have used the prevailing standard form.

Pervez Rizvi (15 Blake Road, Croydon, UK, CR0 6UH) is an independent student of Shakespearean textual criticism and bibliography. 
stemmata, one that enables them to be more rigorous, while remaining easy to both compose and comprehend.

In this note I shall present three examples. The first is Gary Taylor's stemma for the transmission of Troilus and Cressida (see fig. 1 ). ${ }^{2}$ Notice that the stemma has seven nodes while the theory of transmission it represents contains only five material objects: the foul papers, the fair copy, the promptbook, the 1609 quarto, and the 1623 folio. Closer inspection reveals that the promptbook and the quarto are shown twice, each at different stages of their lives. It is of course essential to convey this information, but the form in which it has been presented makes it difficult for the viewer to see at a glance how many discrete material objects are actually involved in the transmission of the play.

My second example is taken from the chapter on Henry $V$ in the $\mathrm{Ox}^{-}$ ford Textual Companion (see fig. 2). ${ }^{3}$ The reference to "performances" in the left branch should perhaps have been omitted, since a performance is neither a material object nor a change in a material object. However that is not my main objection. Even if we omit "performances," the stemma shows a line of transmission from the promptbook to the memorially reconstructed manuscript. Of course there may be some connection between the two, since some scholars have argued that the text of $\mathrm{Q}_{1}$ was likely reconstructed from actors' recollections of their parts and what they could recall of others not available when the decision to publish was made. But there is no bibliographical link between the two objects. The theory of transmission represented here does not say that one object was copied or consulted to produce the other: it says the opposite. That is what the theory of memorial reconstruction posits. The stemma correctly uses a dotted line to show that there is some demonstrable textual link between $\mathrm{Q}_{3}$ and $\mathrm{F}$, the former having been consulted when printing the latter. But by using the same convention to connect the promptbook with the memorially reconstructed manuscript, ambiguity is introduced, possibly misleading the reader.

My final example is from Jay L. Halio's edition of the Folio text of King Lear (see fig. 3). ${ }^{4}$ The stemma, as drawn by Halio, does not use arrow heads, but the direction of transmission is perfectly clear. For brev-

2. Gary Taylor, "Troilus and Cressida: Bibliography, Performance, and Interpretation," Shakespeare Studies 15 (1982): 127.

3. Stanley Wells and Gary Taylor with John Jowett and William Montgomery, William Shakespeare: A Textual Companion (Oxford: Clarendon Press, 1987), 375.

4. The Tragedy of King Lear, ed. Jay L. Halio (Cambridge: Cambridge University Press, 1992), 70. 


\section{Stemmata for Shakespeare Texts}

ity, Halio has conflated two stages of transmission into one: the Quarto Copy $Y$ was of course printed in 1608 and revised around 1611-12, so two nodes should be shown. But my main objection concerns the initial impression that the foul papers were put to three uses: to create a fair copy, to print Quarto Copy X, and to print Quarto Copy Y. However this is misleading, since the production of copies $\mathrm{X}$ and $\mathrm{Y}$ occurred as part of the same print run and thus constitutes only one node, or stage of transmission. The stemma correctly shows Copy $\mathrm{X}$ and Copy $\mathrm{Y}$ as different material objects, but implies they emerged from separate processes.

Rather than state abstract rules governing the new form of stemmata that I wish to recommend to Shakespeare scholars, I have redrawn each of the stemmata discussed above in the new form, while remaining faithful to the theories of transmission they present. The rules will be apparent from my discussion of the new diagrams.

Figure 4 re-presents the information in Figure 1, using the new form. The left column gives a list of all the material objects involved in the transmission. As I noted above, there are five of them, and it is now possible to see and count them at a glance. Each horizontal line of shapes is known as a "swim lane," a term borrowed from diagrams drawn in business process analysis. As is the case in mathematical and scientific diagrams, time runs from left to right.

Each swim lane shows, in chronological order, the different states of the material object identified at the start of the lane. Each rectangular box represents a material and textual transformation of that object during its life. Here, the topmost swim lane shows Shakespeare's creation of the foul papers, his autograph manuscript. A little further down, the fourth swim lane shows "Jaggard's Exemplar," a particular copy of the 1609 quarto based on the foul papers, which was subsequently annotated in 1623 .

Each unbroken arrow between two objects, $\mathrm{A} \rightarrow \mathrm{B}$, tells us that object $A$ was used to create object $B$, most often by a process of copying or printing. A dotted arrow tells us that the relationship was one of consultation rather than copying. In this example, we see that the foul papers were used to create the fair copy, but that Shakespeare consulted rather than copied the former to create the latter. By contrast, the third swim lane shows that the scribe copied the fair copy to create the promptbook. No arrow is drawn between the nodes "Copied by Scribe" and "Revised by Shakespeare" since these are different stages in the life of one material object. That information is already conveyed by the fact that the two nodes are in the same swim lane. An arrow is drawn only to show one 
material object being used in the creation or alteration of another.

Figures 1 and 4 represent exactly the same information, but in different forms. Figure 4 offers several advantages over Figure 1:

1) It allows the material objects to be instantly identified, by looking down the left-hand column;

2) It separates object from process;

3) By looking from left to right along a swim lane, it is easy to see the stages an object goes through in its life;

4) It is visually more coherent.

I may deal with the other two examples more briefly. Figure 5 presents the information in Figure 2, using the new form. Notice that, unlike Figure 2, here we have no arrow between the promptbook and the memorially reconstructed text. This shows that the material object called the promptbook was neither copied nor consulted in creating the material object called the memorially reconstructed text. We have no reason to suppose that the promptbook was available to the creators of the memorially reconstructed text, so it would be misleading to connect the two objects by an arrow. The diagram reflects the reality that the memorially reconstructed text, like the foul papers, was created de novo.

Finally, Figure 6 presents the information in Figure 3, using the new form. The significant point to notice here is that, because the theory of transmission involves two different copies of $\mathrm{Q}_{1}$, called copy $\mathrm{X}$ and copy $\mathrm{Y}$, both are shown as different material objects, each in its own swim lane. The unbroken line between them, with no arrowhead, tells us that they came into existence in the same operation, the printing in 1608 . Thereafter, each copy enjoyed its own fortune: $\mathrm{Y}$ was marked up with revisions by Shakespeare and then used to create a promptbook, while $\mathrm{X}$ came into the possession of the printer of Quarto 2.

Figures $4^{-6}$ demonstrate how my proposed stemmata scheme clarifies the difference between object and process while minimizing possible ambiguities. Usually one would arrange the swim lanes in chronological order of creation of the material objects, the earliest object being in the top swim lane. But it is not essential to do this. The two stemmata in Figure 7 convey exactly the same information.

From both stemmata, we learn that $\mathrm{A}$ was used to create $\mathrm{B}$, which was then used to create $\mathrm{C}$. The order of the swim lanes is not significant. Sometimes, when drawing a complex stemma, two arrows may cut across each other. While not diminishing the accuracy of the diagram, such in- 
felicities clutter the image and introduce possible confusion. However, by placing the swim lanes in a different order, one can often eliminate intersecting lines and thus clean up the image. Sometimes, it may also be more convenient to draw the stemma in portrait rather than landscape form, with the material objects along the top and the swim lanes running vertically downwards. In such a diagram, time would be understood to run from top to bottom rather than from left to right.

I have tried to keep the new form as simple as possible, to make stemmata easy to draw, whether using pen and paper or software. The standard commercial software for drawing such diagrams is Microsoft Visio, which unfortunately is expensive. However, I have drawn all diagrams in this note using web-based software called Lucidchart, ${ }^{5}$ which I have found easy to use. It comes in both free and paid-for versions; the free version was more than adequate for the diagrams I have presented here. Lucidchart also allows diagrams to be saved at a resolution of $300 \mathrm{dpi}$, which publishers usually require.

I hope that scholars will make use of this new form, which, I respectfully suggest, is, for theories about the transmission of Shakespeare texts, an improvement on the traditional form.

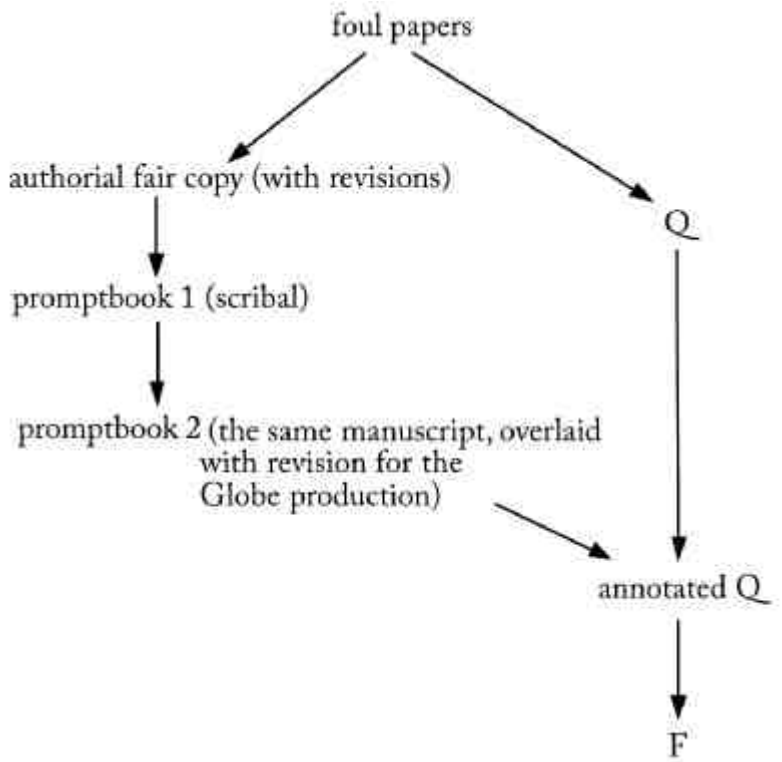

Fig. 1: Gary Taylor, "Troilus and Cressida: Bibliography, Performance, and Interpretation," Shakespeare Studies 15 (1982): 127.

5. See http://www.lucidchart.com. 


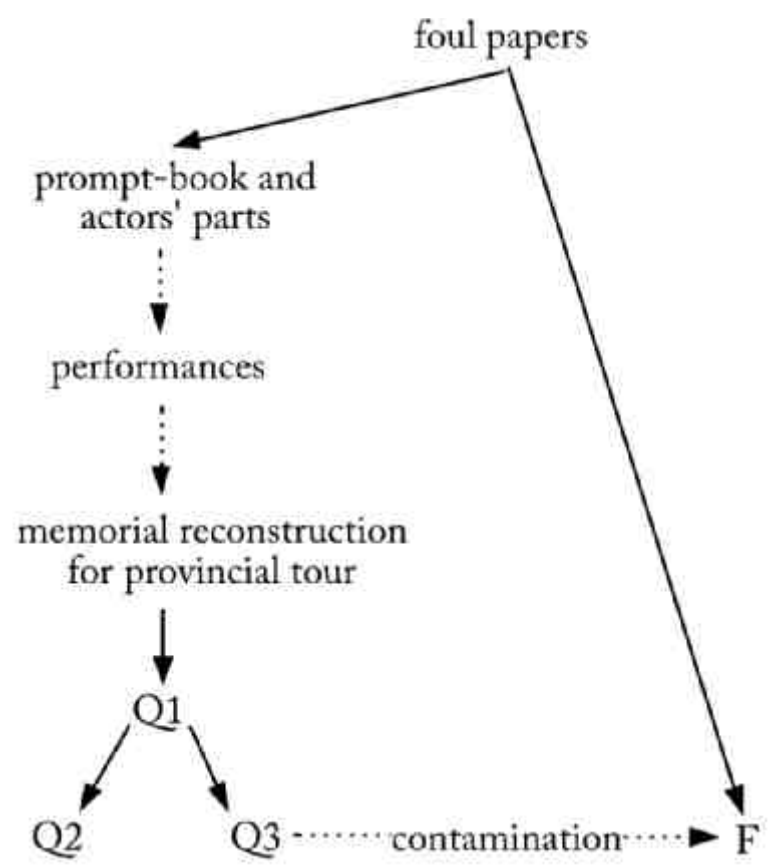

Fig. 2: Stanley Wells and Gary Taylor with John Jowett and William Montgomery, William Shakespeare: A Textual Companion (Oxford: Clarendon Press, 1987), 375.

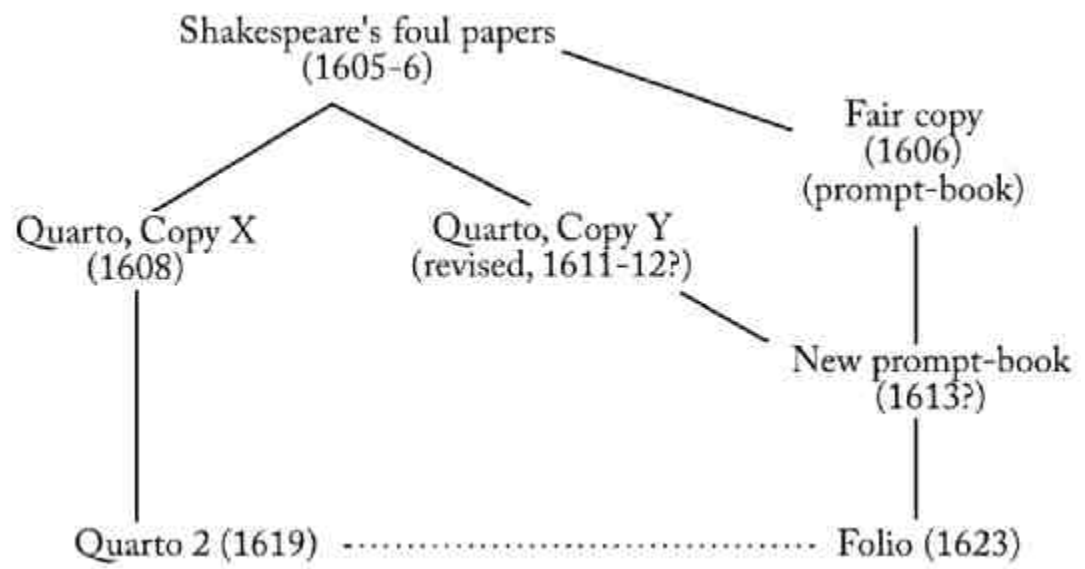

Fig. 3: The Tragedy of King Lear, ed. Jay L. Halio (Cambridge: Cambridge University Press, 1992), 70. 


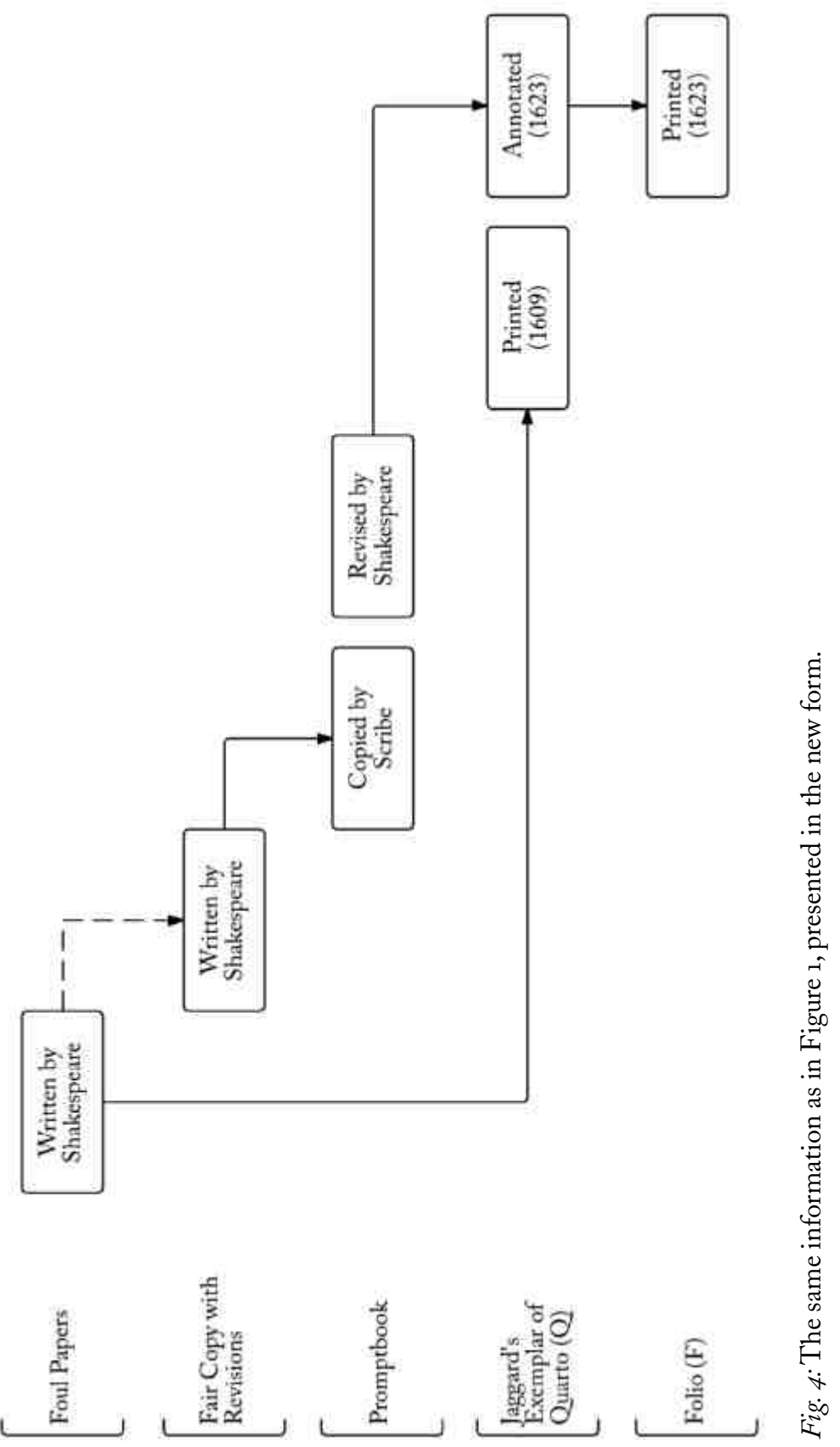




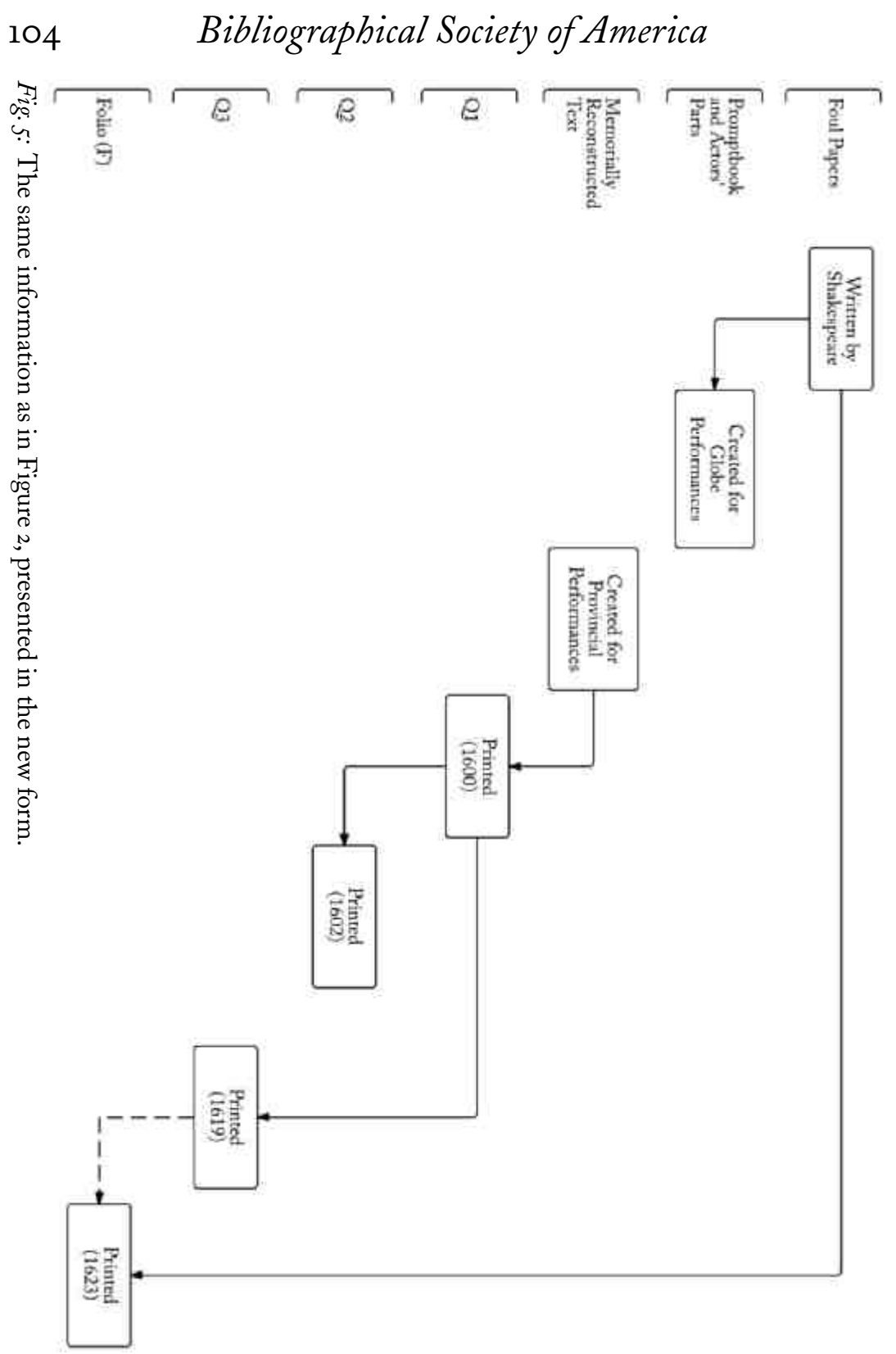




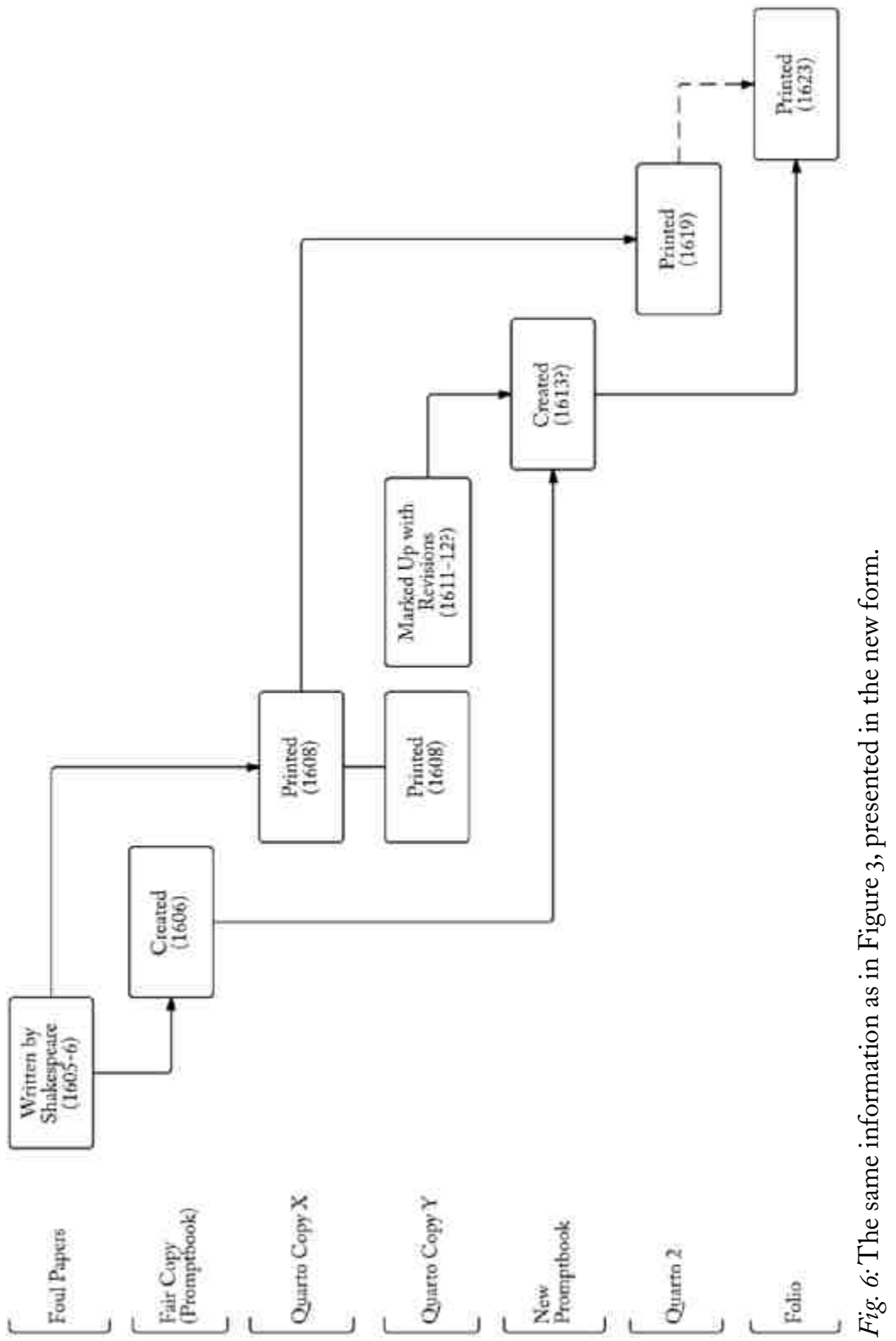



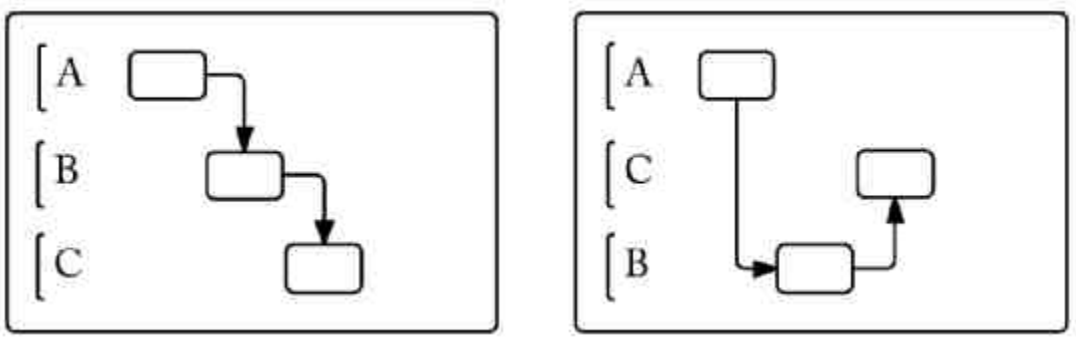

Fig. 7: Swim lanes arranged in different orders convey the same information. 


\title{
Finding Matthew Parker in Manuscripts of the Anglo-Saxon Chronicle
}

\author{
Nicholas A. Sparks
}

I SOLATED IN SPACE AND TIME: a man, a name, and a scribe called the “Talbot annotator," who added various annotations to manuscripts of the Anglo-Saxon Chronicle and other volumes mainly in the collection that Matthew Parker (d. 1575) donated to Corpus Christi College, Cambridge. The "Talbot annotator" is the protagonist of this story, and consideration of the way he used these manuscripts, the subject of this note.

The "Talbot annotator" is well known in the field of Chronicle studies, though the name, that is, the sobriquet, is still young-it sprang from the literature of the last century. The name was coined by Janet Bately in her 1986 edition of The Parker Chronicle, also cited as MS A. ${ }^{1}$ However, new evidence about him has recently emerged as part of textual work on a forthcoming digital facsimile edition of The Peterborough Chronicle, also cited as MS E, now in the Bodleian Library, information that calls into question our scholarly assumptions about his identity. ${ }^{2}$ What follows is a reasessement of the "Talbot annotator" in light of this evidence.

1. The chronicle itself occupies fols. $\mathrm{I}^{\mathrm{v}}-32^{\mathrm{v}}$ of Cambridge, Corpus Christi College MS 173; CCCC used for subsequent references to books in Cambridge, Corpus Christi College. Janet M. Bately, ed., The Anglo-Saxon Chronicle: MS A, The AngloSaxon Chronicle: A Collaborative Edition (Cambridge: D. S. Brewer, 1986), xlv.

2. Bernard J. Muir and Nicholas A. Sparks, eds., A Digital Facsimile of Bodleian Library, MS Laud Misc. 636, "The Peterborough Chronicle," Bodleian Digital Texts 4 (Oxford: The Bodleian Library, forthcoming).

Nicholas A. Sparks (Dept. English (SLAM), University of Sydney (A2o), NSW 2006, Australia) is at present affiliated with the Medieval and Early Modern Centre, University of Sydney and the Institute of English Studies, University of London. 
The best account of the writer of these notes is in the 1954 facsimile edition of The Peterborough Chronicle, ${ }^{3}$ where Dorothy Whitelock, whose analysis forms the basis of this note, described the annotator's hand as "sixteenth century" - which it is - and goes on to identify the notes and marks in that hand in that particular Chronicle manuscript. Then, casting the net a little wider, she identified signs of his active interest in other books, mainly associated with Parker and his circle. Those annotations in the The Peterborough Chronicle are located on fols. $11^{\mathrm{v}}, 14^{\mathrm{r}}, 5^{8^{\mathrm{r}}}$, and $59^{\mathrm{v}}$, and especially the long one on fol. $34^{\mathrm{r}}$, which reads in part: "R. talbot in suo Itinerario refert ad a ' 890 ' et chron. Sax. cantuar" (the date 890 stands in rasura, having manifestly been altered).

This note refers to the antiquary Robert Talbot ("R. talbot") and his commentary on the Itinerarium Antonini ("suo Itinerario") 4 in which is inserted a Latin rescript of the annal 893, derived from the version of the Anglo-Saxon Chronicle, known as the F-text or the Domitian Bilingual. Three manuscript copies of the Itinerarium are currently among the holdings of Cambridge College libraries, a fourth in Cambridge University Library, and a fifth copy, at the British Library, is in John Joscelyn's "Notebook," which he probably derived from one of the Corpus Christi books; a few smaller extracts are shelved in different classes in the Bodleian Library at Oxford University. ${ }^{5}$

However, the "Talbot annotator" is not, as Charles Plummer originally proposed in 1899, Robert Talbot himself (Whitelock disposed of Plummer's claim on paleographical grounds). ${ }^{6}$ Therefore, we need to

3. Dorothy Whitelock, ed., with Cecily Clark, The Peterborough Chronicle (The Bodleian Manuscript Laud Misc. 636), Early English Manuscripts in Facsimile 4 (Copenhagen: Rosenkilde \& Bagger, 1954).

4. For an account of Talbot's life see James P. Carley "Talbot, Robert (1505/61558)," Oxford Dictionary of National Biography (Oxford: Oxford University Press), doi:10.1093/ref:odnb/26941. Talbot's work, first printed in Oxford under the title Annotationes in eam partem Antonini Itinerarii que ad Britanniam pertinent, appears in the third volume of The Itinerary of John Leland the Antiquary, 9 vols. (Oxford: 1710-12). For further discussion and identification of Talbot's source, see Timothy Graham, "Anglo-Saxon Studies: Sixteenth to Eighteenth Centuries," in A Companion to Anglo-Saxon Literature, ed. Phillip Pulsiano and Elaine Treharne (Oxford: Blackwell Publishing, 2001), 416-17.

5. CCCC Ms. 379 (Talbot's autograph); CCCC Ms. 101 (the basis of Hearne's edited text); Gonville and Caius College Library Ms. 391 (with annotations by John Caius); a partial copy ("imperfectæ et depravatæ") in Cambridge University Library Ms. Dd. 3. 88; and British Library, Ms. Cotton Vitellius D. vii.

6. Charles Plummer, ed., Two of the Saxon Chronicles Parallel, 2 vols. (Oxford: Clarendon Press, 1892, 1899; repr. with two notes by D. Whitelock, 1952), 2:xxxiv. 
distinguish very clearly the writer of the "Talbot annotator" notes from the antiquary Talbot. To persist in referring to the scribe whose hand is found in books mainly from Parker's collection at Cambridge as the "Talbot annotator" is misleading, and that name is best abandoned.

Further notes in the same hand occur in both the Parker and Peterborough Chronicles, often, though not invariably, in connection with passages underlined in red crayon, marks that indicate those volumes were either used or owned by Matthew Parker. ${ }^{7}$ In both Chronicles, events these marks highlight relate the doings of archbishops, bishops, and other persons involved in affairs of church and state. In the margins of The Parker Chronicle, for instance, the hand responsible for a similar entry on fol. $16^{\mathrm{v}}$ : "R. Talbotus in suo Itinerario transfert hec verba in Latinum." The same hand also made an appearance on fols. $1^{\mathrm{r}}$ and $32^{\mathrm{r}}$, which Neil Ker identified as in the hand of Matthew Parker. ${ }^{8}$ The note on fol. $32^{\mathrm{r}}$, beside the first few lines of the Acta Lanfranci, reads: "hec habentur in lib $^{\circ}$ s. aug. cui titulus est Diversi tractatus monasterii s. augustini." This refers to a complex miscellany from St. Augustine's, Canterbury, ${ }^{9}$ formerly in Parker's possession but marked in the Corpus Christi copy of his Register as already missing by the time the collection was bequeathed to the college. ${ }^{10} \mathrm{~A}$ related note on $\mathrm{p} .351$ of the Lambeth manuscript, also located beside the Acta Lanfranci, reads: "excerpta sunt de antiquo libro anglico ecclesie Christi," which must refer back to The Parker Chronicle.

An examination of other instances of this hand in The Parker Chronicle reveals further paleographic similarities. The modern title, inscribed in ink at the head of the present first folio leaf, reads "chronica scripta anno 23 etatis alfredi Annales Saxonici," and Ker identified the hand as that of Matthew Parker. If we compare the modern title and the notes on fols. $16^{\mathrm{v}}$ and $32^{\mathrm{r}}$, a common scribal hand begins to emerge. One more

7. On notes in the red crayon, see C. E. Wright, "The Dispersal of the Monastic Libraries and the Beginnings of Anglo-Saxon Studies," Transactions of the Cambridge Bibliographical Society 1, no. 3 (1951): 228.

8. Neil. R. Ker, Catalogue of Manuscripts Containing Anglo-Saxon, (1957; repr. with suppl., Oxford: Oxford University Press, 1990), lii.

9. Currently in the Lambeth Palace Library, Ms. 1213. See Montague Rhodes James, A Descriptive Catalogue of the Manuscripts in the Library of Lambeth Palace (Cambridge: Cambridge University Press, 1930-32), cit. no. 1213.

10. CCCC Ms. 575 is the Parker Register. For discussion see Raymond I. Page, “The Parker Register and Matthew Parker's Anglo-Saxon Manuscripts," Transactions of the Cambridge Bibliographical Society 8 (1981): 1-17. 
annotation, on fol. $2 \mathrm{O}^{\mathrm{r}}$, beside the annal 900 where Alfred's death is underlined in red, bears a cross reference: "in lib ${ }^{\circ}$ petriburg. 28 annis et dimidio," and, of course, this is The Peterborough Chronicle, where the date of Alfred's death is given in terms of the Roman calendar, " 7 kal. Novemb." (26 October). That this is the same hand is undeniable, linked by certain paleographic features: the round $a$ with back and bow joined; $b$ and $l$ with long ascenders; the distinctive $g$ with sweeping tail; $p$ with a crossed bow and descender looped-back; and superscript $o$ as in "lib" all the same as in fol. $32^{\mathrm{r}}$.

Other books in Parker's collection bear similar annotations. For example, as Whitelock notes, throughout his copy of Sigebert of Gembloux's Chronica, several passages are underlined in red, accompanied by notes in Parker's own hand. So too does another Parkerian volume, a collection of historical items, mainly antiquarian transcripts, in Latin and Old English, containing inter alia, a transcript of Talbot's commentary on the Itinerarium Antonini. ${ }^{11}$ One particular note on p. 416 reads "In chro a saxonica petriburgensi . hec verba sunt in $\mathrm{a}^{\circ} 89[$ [.] sed in chro. saxo ${ }^{\mathrm{a}}$. cantuariensi est in an $^{\circ} 893$." The numeral "89[.]," trimmed at some point by binders, can be supplied by The Peterborough Chronicle, where the corresponding entry appears under annal 892.

However, Whitelock apparently missed significant further entries in the same hand toward the end of this volume, a list of eminent men named Matthew that James identified as in Matthew Parker's handwriting. ${ }^{12}$ Finally, there is a further single entry by the same hand in Talbot's autograph copy of his commentary on the Itinerarium Antonin $i^{13}$ that Whitelock failed to consider. Had she done so, she would have seen the cross reference at fol. $52^{\mathrm{v}}$, whose wording closely resembles that in Parker's collection of historical items: "hec chronica saxonica . est ecclesiæ cantuar. quonda $m$. et chronica peterburgensis habet eade $m$ verba in $a^{\circ}$ 892." 14 The "chronica saxonica" of Christ Church, Canterbury is, of course, none other than The Parker Chronicle. The earliest known reference to it after the dissolution of the monastaries is when it was already

11. CCCC Ms. 101.

12. James, Corpus Christi, cit. no. 101. See also R. I. Page, Matthew Parker and his Books, Sandars Lectures in Bibliography, 14, 16, and 18 May 1990 at the University of Cambridge (Kalamazoo, MI: Medieval Institute Publications, Western Michigan University, 1993), 126.

13. CCCC Ms. 379.

14. See Hearne, The Itinerary of John Leland the Antiquary, 2nd ed., 9 vols. (Oxford: $\left.1744^{-45}\right), 3: 158$. 
the property of Dr. Nicholas Wotton (d. 1567), first dean of Canterbury, whence it came to be known to Parker and his circle, especially to Joscelyn, who compiled a list of sources for the Anglo-Saxon Chronicle, whilst the book was still in Wotton's possession. ${ }^{15}$

One task remains - the identification of the hand. To whom are we to attribute these annotations in Parker's books? My work indicates that the obvious answer is in this case the right one: the annotator is none other than Matthew Parker himself. Distinctive letter forms support this claim: the idiosyncratic $e$; the $s$ shaped like an integral sign; the $f$ shaped like an integral sign; the letter $b$ that assumes a very distinctive shape; the suspension stroke over the preceding vowel for final $m$. For comparison, authenticated examples of Matthew Parker's handwriting in Greg's English Literary Autographs support this identification. ${ }^{16}$

It may be of interest to recall Page's analysis of the variety of Parker's handwriting throughout the course of his career; a matter which seems to call for further discussion by paleographers. ${ }^{17}$

15. British Library, Ms. Cotton Nero C. iii, fol. 208 ${ }^{\mathrm{r}}$. For an edition of Joscelyn's list, see Timothy Graham and Andrew G. Watson, ed., The Recovery of the Past in Early Elizabethan England: Documents by John Bale and John Joscelyn from the Circle of Matthew Parker, Cambridge Bibliographical Society Monograph 13 (Cambridge: Cambridge Bibliographical Society, 1998), 55-59.

16. W. W. Greg, ed., English Literary Autographs: 1550-1650 (Oxford: Oxford University Press, 1925-32), cit. no. lxvii.

17. Fittingly, Page wrote, "I have been amazed, and depressed, to find out how often, as I have laboriously worked through a range of manuscripts to a particular conclusion, Dr. Ker has beaten me to it"; and Professor Page has done the same to me (Page, Matthew Parker, 90-91); a fact of which I was ignorant when I wrote the above; in memoriam, R. I. Page. 


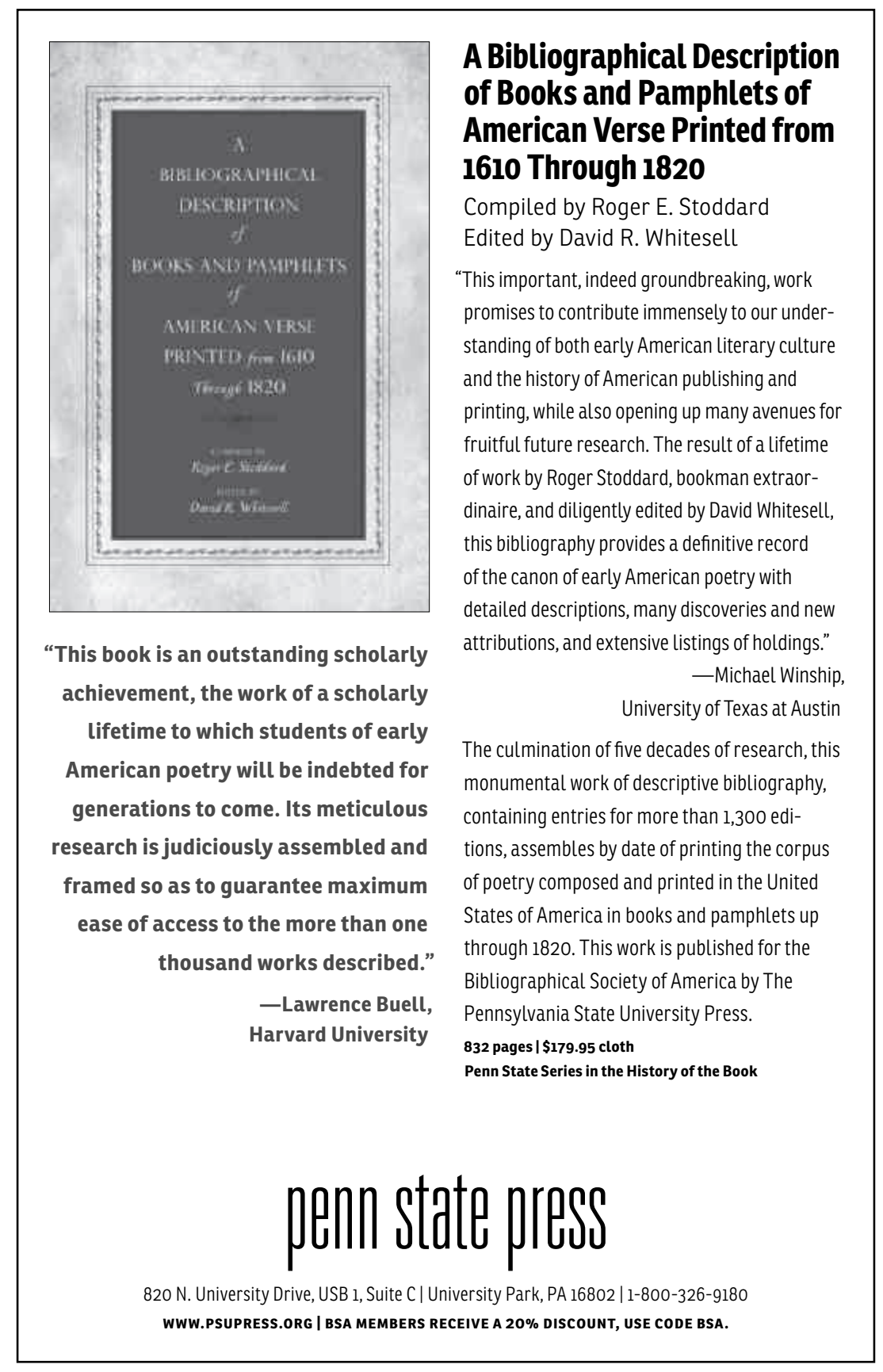




\section{BOOK REVEIWS}

Bland, Mark. A Guide to Early Printed Books and Manuscripts (Malden, MA; Chichester, West Sussex: Wiley-Blackwell, 2010). x, 236 pp. \$115.95. Illus. (ISBN 978-1-4051-2412-6)

Reviewed by Kevin J. Donovan

Over the past twenty years, Mark Bland has published a dozen or so illuminating articles on the historical and cultural significance of English printed books and manuscripts from the late-sixteenth and early- to mid-seventeenth centuries, mainly, though not exclusively, concerned with Ben Jonson's texts. This Guide, a product of his long immersion in rare book libraries and his wide reading in bibliographical and textual scholarship, provides a valuable vade mecum to researchers, both beginners and experienced scholars, who work with documents from this period. Individual chapters discuss such topics as paper, format, methods of textual production, the interpretation of bibliographical evidence, etc. - the topics of analytical and descriptive bibliography that one would expect from such a guide. The Guide also provides a spirited defense of the value of bibliography as a contribution to the historical understanding of human culture.

A particular guiding light for Bland is D. F. McKenzie's orientation of bibliography toward a "sociology of texts" and toward books as expressive forms apart from their verbal content (he was McKenzie's student at Oxford). Bland likewise cites studies by Mirjam Foot, Hugh Amory, Randall McLeod, and other bibliographers and textual scholars interested in "the connection between material evidence and broader social narratives" (18). While his account of the material practices involved in producing manuscripts and printed books is thoroughly grounded in knowledge of their relevant technological, economic, and commercial contexts, Bland insists on the importance of aesthetics to a

Kevin J. Donovan (Professor of English at Middle Tennessee State University, Murfreesboro TN 37132) is the co-editor of a two-volume anthology, Irish Drama of the Seventeenth and Eighteenth Centuries (2003) and the author of the historical survey of interpretive criticism of King Lear for the forthcoming New Variorum Shakespeare edition of that play, for which he served as associate editor. Since 1991 he has co-directed the biennial Conference on John Milton sponsored by MTSU, where he has also coordinated a series of educational residencies by Shakespearean Actors from the London Stage. He is currently completing a survey of recent scholarship on Ben Jonson, on whose texts he has published essays in the past. 
proper understanding of the forms and uses of books and manuscripts: "without an understanding of the role of aesthetics in the making" of documentary materials and their texts, "we know not what we do" (21).

The appearance to the eye of books and manuscripts is given particular emphasis. Bland begins by drawing an analogy between examining a document and forming an impression of someone's personality from their handwriting: "Looking at early printed books and manuscripts requires the same kind of visual, tactile, and historical discrimination: memory, comparative analysis, and sensory perception are fundamental skills that are as much applied as they are theoretical" (2). Later, an account of manuscripts and their uses classifies them in such a way as "to shift the emphasis from a concern with content towards the appearance on the page" (101), which will to the experienced eye indicate the original source or function of a particular document. Likewise, Bland discusses how an owner's choice of bindings "is revealing about the social and cultural values that shaped a collection, and (in cases of patronage) the role of the author in the presentation of a copy" (79-80), a point Bland illustrates with examples from extant volumes of Jonson's works in contemporary bindings.

Informed seeing requires a knowledge of the norms and conventions used in the material forms of documents. Various chapters usefully identify such conventions in order to make exceptions stand out. Thus in "Paper and Related Materials," Bland points out that "the jug, or pot, to be found in paper from northern France is the most familiar watermark in sixteenth- and seventeenthcentury English books and manuscripts, to the extent that it was for many years the ordinary stock of the publishing trade, and a standard for writing paper. Thus when a printed book is not on pot this may be of interest" $(26-27)$. In the same chapter's discussion of fine paper, we learn that "Spanish and Italian papers have wide chainlines, superior whiteness, and a light texture: Bacon and Northampton, as well as Jonson, had a taste for paper of this kind and used it almost all the time" for their manuscripts (43). Similarly a chapter on "The Structure of Documents," which discusses format and other topics conventionally treated by descriptive bibliography, especially focuses on "why books have the format, structure, or binding they do, and what this might communicate about their purpose and use" $\left(5_{2}\right)$. Here too Bland cites significant anomalies: Archbishop Laud's manuscript diary, folded in an extraordinary long decimosexto format, is cited as a marked departure from convention; so is the second issue of Benson's pirated 1640 edition of Jonson's Q. Horatius Flaccus his Art of Poetry, with its very unusual pattern of signatures caused by cancels and insertions which were made in order to accommodate Benson's late acquisition of a superior text of The Masque of Gypsies.

Complementary to its concern with identifying bibliographical norms and conventions, and any significant departures from them, the Guide is also particularly careful to warn bibliographers against erroneous assumptions about 
regularity in the production of books that are based on inadequate or incomplete evidence. For instance, Bland observes that "all too often, arguments about the market for books assume that a printer or publisher would maximize production and income, and that this drove the organization of work in hand. Trade practices tell a different story: concurrent production and shared printing ensured that the organization of activity was consistent in volume, and flexible in its use of materials, thus avoiding erratic fluctuations in staff caused by shortages of work in hand" (137). Sometimes overlooked in other studies are "the social and familial links that glued many business relationships together. It is friendship, not logic or profit, that led to the work being shared for [Francis Godwin's Annales of England (1630)] in the way that it was" (137). Bland singles out compositor identification as originally developed by Charlton Hinman as an area in which bibliographers are especially prone to err due to relying on incomplete evidence. Accordingly he identifies five areas that need to be addressed before undertaking to distinguish compositors: (a) consistency in the underlying copy; (b) sufficient distinctiveness in compositors' habits; (c) removal from consideration of spelling variants in justified lines; (d) the need to analyze the text "line by line, not page by page, because one compositor can take over from another at any point" (140); and (e) careful analysis of the type to determine if more than one case was used, or if there are differences in the layout of the pages and the level of accuracy in the typesetting. Incomplete evidence is also cited by Bland as a serious problem in any discussion of the sixteenth- and seventeenth-century English book trade that overlooks the significant role of books imported from the Continent, especially in Latin: "Without an understanding that imported books would have constituted a major portion of any bookseller's stock, our sense of the trade is radically incomplete" (210).

Among the particular virtues of the Guide are its helpful practical instructions on such matters as analyzing and describing laid paper, identifying the date or origins of a document on the basis of its paper, distinguishing compositors, and calculating composition by ens (a more reliable way of estimating a printer's output than the number of edition sheets). A chapter on textual variants includes practical instructions regarding collating, establishing the order of variants, and stemmatic analysis.

Also valuable are a number of particular insights about books and manuscripts in society. For instance, Bland notes that "the overall size of the [English book] trade was, for a long time, quite modest. . . . It is likely that Southampton, Egerton, Pembroke, and Cecil each had a greater personal net worth than the asset value of the trade as a whole: that places their relationship with Shakespeare, Donne, Daniel, and Jonson, and their ability to protect them, in a rather different perspective" (202). A discussion of censorship during the period sensibly sides with Cyndia Clegg's interpretation of the evidence against Annabel Patterson's, arguing that "the mechanisms of control existed more to 
assuage official and public concern than to enforce an ideology" (200). The argument is supported by brief overviews of the licensing activities of three chaplains to bishops who served as ecclesiastical censors: Abraham Hartwell, William Barlow, and Zacharaiah Pasfield. The evidence suggests that authors "might approach a chaplain known to be sympathetic to their work; hence the fact that the same person could have all his work authorized by a single chaplain, regardless of the publisher" (190-91). Pasfield was apparently "preferred by Jonson" (192) until the Master of the Revels Sir George Buc took over licensing of printed drama. "It was, in fact, only those who lacked patronage, that were liable to have their texts altered by authority" (199). Bland also takes issue with Peter Blayney's claim that Nicholas Okes's printing house operated significantly differently from normal practice by producing books sequentially rather than concurrently. Blayney's rationale for claiming that Okes produced books sequentially rather than concurrently is "based on an argument of urgency, and the need for rapid turnover and cash-flow" (141); Bland finds insufficient evidence for both claims.

The Guide ends with a spirited defense of bibliography and the value of actual books and manuscripts rather than digital images to historical understanding, returning to the idea that underlies the entire book: that material books and manuscripts have far more to tell us than their verbal content alone. In what may be the most eloquent passage in the book, Bland decries the divergence of public funding from the maintenance of libraries' physical collections:

Instead of arguing from high moral principle for the provision of adequate funding, those concerned collude in the belief that the book is only a text, that a text is only information, and that the physical copy can be discarded and replaced by a digital image. At the same time, the funding that ought to be devoted to libraries, and the maintenance of the human written record, is instead diverted by governments into projects that seek to gather information of an ever more intrusive nature on the lives of private citizens. The pursuit of information at the expense of knowledge and understanding as represented by considered written discourse, the privileging of political self-interest over a broader ethical responsibility that ought to be at the heart of civilized government, and the claim that such institutions have the assumed right to control the behaviour of others rather than tolerate the liberty of individual conscience, has quietly been pursued by the lights of perverted science $(216-17)$.

Like his mentor McKenzie, Bland persuasively locates bibliography, too often regarded as peripheral dryasdust pedantry, at the heart of humanistic scholarship.

The book is not without faults. The prose style is sometimes pedestrian and there are some minor errors or faults that could have been caught by more careful editing. For instance, the index includes an entry for Laud, but it overlooks the reference to him which has been cited above; it also misspells Nicholas Okes's name. Heidi Brayman Hackel's Reading Material in Early Modern Eng- 
land is rendered as Reading Materials (215n). There is an erroneous reference to the "Pied Bull quartos of Shakespeare, with their false imprints," where the Pavier quartos are clearly intended (200); presumably this was a momentary lapse explainable by the fact that the first quarto of Shakespeare's King Lear is frequently referred to as the Pied Bull quarto while the second quarto of that play is one of the notorious Pavier quartos. In addition, I think that Bland seems to accept too uncritically the largely discredited accounts by Steven Urkowitz and Gary Taylor that ascribe virtually all of Folio Lear's textual differences from the Quarto to Shakespearian revision.

However, these are minor flaws in what is a valuable contribution to bibliographical and textual scholarship. A Guide to Early Printed Books and Manuscripts admirably succeeds in its stated goal of complementing Gaskell's New Introduction to Bibliography. It belongs on the shelf of any scholar working with books and manuscripts from the sixteenth and seventeenth centuries, especially since it is now available in paperback at an affordable price.

Mak, Bonnie. How the Page Matters. Studies in Book and Print Culture. Toronto: University of Toronto Press, 2011. xii, $129 \mathrm{pp}$. Col. Illus. Cloth, \$55.00 (ISBN 978-o-8020-976o-6); Paper, \$24.95 (ISBN 978-1-4426-1535-9).

Reviewed by BRETT A. Hudson

Bonnie Mak's How the Page Matters is a small volume, but one that engages a very large subject. In it, she presents a concise historical and comparative examination of how the organization of the spaces in which ideas are transmitted to readers has adapted to various textual technologies, exploring how the page as interface - whether in a medieval manuscript, printed book, or computational device - matters to the production of meaning. According to Mak, the architecture of the page - physical or digital - involves "a complex and responsive entanglement of platform, text, image, graphic markings, and blank space," one in which the designer of the page influences the engagement of a reader with a text (5). How the Page Matters is situated firmly within the emerging discussions over the importance of digital humanities to textual and bibliographic criticism. Mak's central argument is that the concept of pagina, the discrete, rectangular unit of text familiar to readers throughout the ages, has extended

Brett A. Hudson (Middle Tennessee State University, Box 70, 1301 East Main Street, Murfreesboro, TN, USA, 37132) is a Lecturer in the Department of English. His research is on early modern nonconformity, prison literature, reading practices, and book reception. He writes on John Milton, Andrew Marvell, John Bunyan, and nonconformist biography. He has a chapter on Bunyan's The Pilgrim's Progress in Prison Narrative from Boethius to Mehdi Zana, edited by Philip Phillips (forthcoming 2014). 
beyond the physical dimensions of papyrus scroll, parchment manuscript, and printed codex to engage with a variety of digital platforms, a move that needs to be investigated. Furthermore, Mak argues against a simplistic binary opposition that views digital and analogue pages as somehow distinctly different phenomena - after all, texts are written by hand on digital devices, and born-digital texts are printed onto paper. Thus, certain strategies used in the production and consumption of the textual page have been translated from past and current print practices to emerging digital technologies - a borrowing of knowledge and insight whose origins Mak locates in the western transition from the scroll to codex some 2,00o years ago.

The backbone running through Mak's examination of the page is her meticulous analysis of Controversia de nobilitate, a Latin treatise on homo novus written by the fifteenth-century Florentine humanist and jurist Buonaccorso da Montemagno, and a text that spread across Europe and was translated into and published in many other languages, including Italian (Trattato della Nobilità), French (La Controversie de Noblesse), and English (Declamacyon de Noblesse). Mak chooses these textual artifacts as the locus of her examination because Buonaccorso's treatise appeared in manuscript, print, and digital forms, and survives on parchment, paper, and computer. Having been modified and codified by scribes and translators, printers and publishers, book owners and readers, librarians and digital archivists, the Controversia provides a particularly rich illustration of how the pages from a single source text retain the "residue" left by various historical, cultural, and technological changes. As one might expect, the scope of Mak's investigation is expansive. In the first chapter she lays the groundwork for her analysis of the Controversia by presenting a brief overview of the many fields that inform her project. She observes that classicists, bibliographers, codicologists, paleographers, literary critics, and others all study the same "text" but interpret it from their own disciplinary perspective: how it appears in different periods, languages, scripts, or physical embodiments, along with the complex set of interpretive nuances that attend such differences. As Mak describes the production of papyrus scrolls, the emergence of the manuscript codex to meet the needs of the expansion of literacy, and the invention and development of late medieval and early modern print technologies, How the Page Matters becomes a valuable introduction to these disciplines; in the process, Mak models the type of conversation needed to "build a foundation for examining the dynamic relationship of materiality and mattering" of analogue and digital pages (10). The history of the page that Mak presents is "one of overlapping methods, materials, and means; the paginae of scrolls and codices have worked concurrently for millennia to organize information and facilitate the transmission of ideas, sometimes on papyrus, sometimes on parchment, and sometimes on paper" (15). 
As Mak moves to her analysis of the Controversia, she becomes highly concerned with textual transmission and how cultures and reading communities developed "pages" that satisfied the needs and values of their textual communities. Mak hopes to show that the pages of the Controversia have been conceived, and have functioned, as "flexible interface[s] that can be the product of multiple technologies and can host a range of visual and verbal agendas" (28). Disappointingly, as she interrogates the pages of various manuscripts and printed editions of the Controversia, questioning the functions, aesthetics, and influences of the paratextual features of the treatise in its various translations and incarnations, she finally provides little insight into the actual cultural, intellectual, and economic pressures in which these features were employed. When in the final chapter she examines digital versions of the Controversia, she again closely studies the pages and models effective methodology for investigation into digitally born texts. She shows how digital pages share similar complexities with their analogue counterparts: how they are "interfaces that provide a point of contact between designer and reader ... [that] communicate verbally, graphically, aurally, and tactilely, and are constructed in a material way that influences how they are read and understood" (62). Therefore, Mak asserts that the digital page is a further manifestation of the pagina, yet there is a distinctness in the digital pages that goes beyond the mere imitation of print or manuscript pages. She points to the computational codes that lie hidden from the text's reader and asserts that the codes themselves are manifestations of cultural, political, and economic pressures, but she does not follow the analysis through to define or explain the nature of these pressures. Nevertheless, Mak provides an exceptional description of her textual criticism as she analyzes the facsimile edition and hypertext transcription of Caxton's 1481 edition of the treatise published by Early English Books Online. There is a careful consideration of how the various poses of authority and accuracy that the EEBO transcription takes. Yet again, as Mak makes suggestions about the differences between the digital versions and their exemplars, she does not go far enough in providing a critical analysis of the importance of these differences. She is primarily interested in revealing the current anxieties about textual transmission, ownership, and similitude in the digital humanities. For example, Mak suggests that EEBO facsimiles might become the dominant English versions of the text and will assume the role of primary exemplar for future texts (68).

The coherence of How the Page Matters loosens in the fourth chapter, "Reading the Library," as Mak's argument takes a detour from the analysis of the physical page. She focuses her study on how the "pages" of the Controversia are "incorporated into [the] places and spaces of knowledge" in which the treatise is held (47). Mak makes this transition because Buonaccorso's treatise contains a treatment of libraries and their connection to nobility. Therefore, she discusses Italian ideas of private libraries and spaces of study and reflection, 
showing how the architecture of private houses demonstrated conceptions of private intellectual reflection versus public work. Mak suggests that the theatricality of the studiolo of Federico of Montefeltro in Urbino was designed for selfexhibition, revealing the owner's interests and intellect to the room's visitors as well as to himself. But Mak's focus on Federico's studiolo and library seems arbitrarily connected to her analysis of the page or to her ongoing case study of the Controversia. Nevertheless, Mak eventually explains how the Controversia was categorized as a rhetorical example in Federico's library, rather than as a history or literary work. Mak then switches from a description of a fifteenthcentury Italian library to the modern Bibliothèque Nationale de France (BNF). She seems to choose to analyze this library system primarily because it holds twenty-two manuscripts and early printed editions of the Controversia and its various translations, which allows the treatise to "participate in multiple systems of classification" that reflect the library's "particular institutional landscape of knowledge" (56). As in many special collections, Mak explains that the most apparent divisions are manuscript and print, even though copies of the text mix technologies: manuscript and print codices are stored in separate locations at five kilometers distance in locations employing separate organizational principles. Furthermore, some manuscripts and printed books are designated as rare, requiring further categorical limitations, such as being house in the Rare Books Reserve apart from the other materials. Mak attempts to theorize on the admission procedures - described in detail by Mak - used by the manuscript and rare print archives of the BNF. Mak writes, "the Reserve bestows upon its holdings and readers a privileged status that influences the ways in which all the books of the library ... are understood" $\left(5^{8}-59\right)$. These architectural and procedural observations lead Mak to make the suggestion that the treatise has "acquired additional ways of mattering in the BNF," according to the facilities and rooms in which the manuscripts and printed books of the treatise are stored, and under which subject guides they are catalogued (59). However, Mak does not explain what exactly are the associations that are being added to the text, only that they are possible.

How the Page Matters is ambitious in its attempt to chart the evolution of the pagina from scroll to screen, and the book's ninety-four pages of criticism and notes leave many questions unanswered. However, for the student and scholar new to bibliographic and textual scholarship, the volume is approachable and engaging. The sixteen full-color plates of illuminated manuscripts, woodcuts, and libraries are clearly rendered and are helpful reference points. Furthermore, Mak's analysis, notes, and bibliography provide an excellent introduction to methodologies and theories used to investigate manuscripts, codices, and digital texts. 
Warner, J. Christopher, ed. John Bale's Catalogue of Tudor Authors: An Annotated Translation of Records from the "Scriptorum illustrium maioris Brytanniae ... Catalogus" (1557-1559). Medieval and Renaissance Texts and Studies, 375. Tempe, AZ: ACMRS, 2010. xl, 427 pp. Hardcover, $\$ 84.00$ or $£ 64.00$ (ISBN 978-0-86698-423-2).

Reviewed by Brett A. Hudson

Within the pages of this present volume are hidden many storylines: the rise of English Protestantism, the development of English drama, the social networks of English Humanists, the blossoming of the English book trade. Though J. Christopher Warner (Le Moyne College) has clearly produced an excellent reference tool, John Bale's bibliographical legacy can be read as the diary of an enthusiastic, though polemically biased, bibliophile. Warner's annotations reveal Bale as he forages through bookshops for new titles; as he scans over book pages, occasionally misreading titles; and as he appropriates the catalogues of other collectors. Out of this overwhelming and, at times, deceptive text, Warner has created a manageable, useful, and clear scholarly resource. In this volume, Warner presents an annotated translation of the Tudor-era title entries from Bale's two-part Catalogue of Illustrious British Authors (hereafter referred to as Catalogue), originally printed in two volumes: Illustrium maioris Brytanniae, quam nunc Angliam E' Scotiam uocant: Catalogus (1557) and Scriptorvm illustrium maioris Brytanniae posterior pars (1559). In its entirety, Bale's Catalogue includes entries or references to over 1,500 English, Scottish, and Irish authors. Out of this extensive list of authors and titles, Warner's condensed volume focuses upon authors who flourished or died during the Tudor period. Thus, Warner annotates and translates the entries of over 1,500 extant and lost works by 237 writers of the late fifteenth and early sixteenth centuries, making this volume a valuable resource, as Warner hopes, to "those who study Tudor political and intellectual history, the English Reformation, early sixteenthcentury literature, and the rise of the printing press and English book culture" (xiii). He has surely succeeded in his goal.

Warner's volume is not designed to stand alone; instead, Warner networks with the scholarship of others as he cross-references the Catalogue's entries with the Pollard and Redgrave Short-Title Catalogue (STC) and with Bale's autograph notebook that survives in the Bodleian Library ${ }^{1}$ (hereafter referred to as $I B S)$. However, Warner's edition is a vital tool for bibliographic research in the Tudor period for the very reason that it contains sixty authors who are not contained in the $S T C$ (such as those whose works were never printed, written in Latin, published on the Continent, or merely are no longer extant).

1. Selden MS. supra 64. The notebook has been published as Index Britanniae Scriptorum: John Bale's Index of British and Other Writers (1902; repr. D. S. Brewer: Woodbridge, 1990). 
Warner's informed introduction and clear apparatus addresses and alleviates many of the inherent characteristics or faults in Bale's Catalogue that have rendered it inaccessible to some modern scholars. The most apparent problem that Warner's translation solves is that the Catalogue is written entirely in Latin. In addition to including the titles of many Latin texts, Bale translated his English titles and their incipits into Latin. Another issue which Warner's volume addresses is that Bale's entries are occasionally confusing, with titles being given in abbreviated form or rather as a descriptive label; furthermore, some titles refer to parts of works rather than to wholes. The scholarship of Warner's annotations and the clarity of his cross-references do much to make the derivation of the Catalogue's more perplexing or redundant titles clear. Furthermore, in his introduction, Warner addresses and reconciles Bale's most frequent errors, which have made him notorious as a bibliographer, such as his ghost entries, double entries, title splitting, and generous use of the term liber as a catch-all term.

Warner's translation retains but clarifies Bale's original classification and reference system. Bale organized his authors by dividing them into groups of 100, which he calls "centuries," and within each century assigns his authors Roman numerals. In order to collect the Tudor-era authors into one volume, Warner assembles together the second half of the Catalogue's eighth century, the entire ninth century, the last eighteen authors of the eleventh century, and all seventy-one authors in Bale's appendix to the twelfth century. Furthermore, Warner regularizes Bale's appendix to the twelfth century by extending Bale's numbering system to it. Additionally, Warner further categorizes the title lists by assigning each title the number of its century followed by its sequence number in the century (e.g. the one-thousandth tile in the eighth century [8.100o] is Thomas Cranmer's [8.XC THOMAS CRANMERVS] Contra primatum Papae, which Warner translates as [Against the Pope's Primacy]). Warner's numbering system allows individual titles to be cross-referenced in his annotations to other titles within Bale's Catalogue. This feature allows Warner to explain authorial, bibliographic, or cultural connections between texts in his annotations.

As mentioned above, in order to make Bale's Catalogue more accessible, Warner provides an English translation of Bale's Latin names, titles, and incipits. Furthermore, Warner cites the dates of the authors' flourishings or deaths as supplied by Bale, or, when possible, the authors' dates from the Oxford Dictionary of National Biography. For the titles of works, Warner cross-references $I B S$ or $S T C$ and indicates when the titles are present in either source. Furthermore, when Bale's titles are identifiable, the annotations supply the full titles, expand the printers' abbreviations, provide the publication dates, and cite the $S T C$ numbers when available. For a title not in $S T C$, Warner provides publication information and a name of a library currently holding the title, and when the title is only extant in manuscript, Warner cites its location, class number, and article, starting folio, or page number. Warner clarifies Bale's notorious 
double entries and split-title entries by providing Bale's earliest reference to the larger work. Additionally, Warner's annotations list Bale's sources as provided in $I B S$. Beyond providing translations to Bale's Latin and referencing and crossreferencing the Catalogue, IBS, and $S T C$, Warner takes the liberty of suggesting possible or probable identifications to works that he cannot identify with certainty. Thus, readers of Warner's volume can only appreciate his effort to provide a comprehensive translation and reference tool.

In addition to the translated and annotated selections of Bale's Catalogue, Warner's volume includes various indices that allow readers to approach the Catalogue's content from different starting points and with varying goals. Preceding Bale's translations of Century 8, Century 9, Century 11, and Century ${ }_{12} \mathrm{~A}$ is the "English Index of Tudor Authors in John Bale's Catalogue." This index provides the century and title number where the author is found in the Catalogue as well as lists whether or not the author is in IBS or STC. Following the Catalogue, there are four additional indices appended to volume: "Appendix A: Index of Extant Works Listed in the Short-Title Catalogue of English Books, 1475-1640 by $S T C$ Number" allows readers to search for works using $S T C$ as a starting point. "Appendix B: Index of John Bale's Latin Names for Tudor Authors in the Catalogue" provides an alphabetized list of author names as they appear in the Catalogue. "Appendix C: Index of John Bale's Latin Titles for Tudor Words in the Catalogue" provides an alphabetized list of titles as they appear in the Catalogue. These specific indices are followed by "Appendix D: General Index," containing an index to the various topics and themes of the works listed in the Catalogue as well as their genres, names of translators, and additional information. These usable indices will likely allow readers of this volume to use Bale's Catalogue pragmatically in their study of Tudor-era book culture; however, readers might still want to take the time to enjoy Bale's bibliographical legacy. 


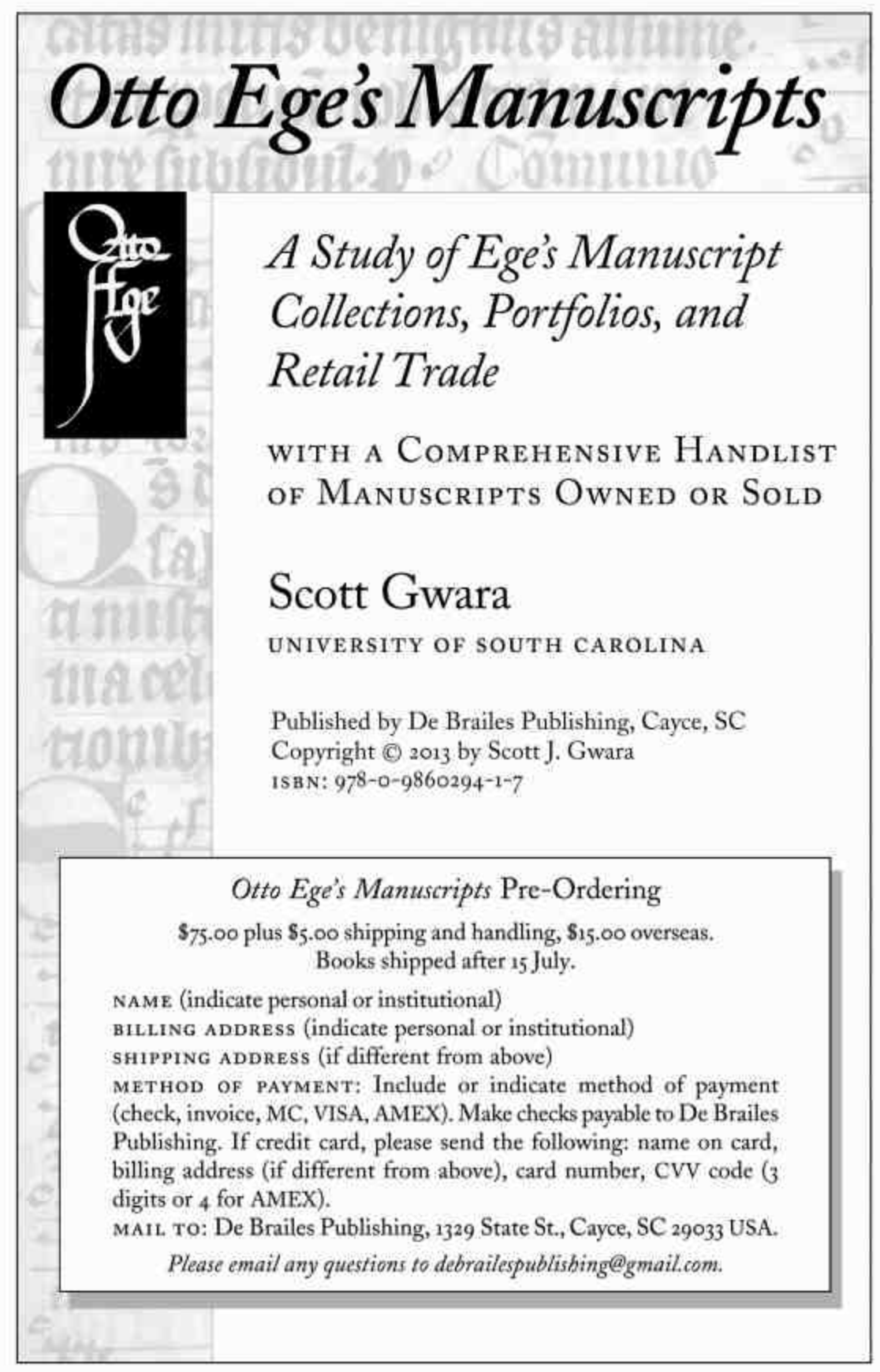




\section{INDEXTO VOLUME 107}

\section{Papers of the Bibliographical Society of America}

Subject entries, whether topical, personal name, or geographical, are set in SMALL CAPITALS. A chronological approach is provided under CHRONOLOGICAL REFERENCES. Geographical entries are made for all articles, notes, and reviews treating a subject that can be localized.

Advertisements: McEvilla, "A Catalogue of Book Advertisements from English Serials: Printed Drama, 1646 $1668, " 10-48$

ALlen, Richard: Phillips, "Versifying African Methodism: or, What Did Early African-American Hymnbooks Do?" 325-333

Arnar, Anna Sigrídur, The Book as Instrument: Stéphane Mallarmé, the Artist's Book and the Transformation of Print Culture, reviewed, 271-278

ASTEll, MARY: Dussinger, "Mary Astell's Revisions of Some Reflections upon Marriage (1730)," 49-79

Astronomy: Johns, "The Uses of Print in the History of Science," (BSA Annual Address), $393^{-420}$

attribution: Dussinger, "Mary Astell's Revisions of Some Reflections upon Marriage (1730)," 49-79; Orr, “The History, Uses, and Dangers of Halkett and Laing," $193-240$

AUThorship: Dussinger, "Mary Astell's Revisions of Some Reflections upon Marriage (1730)," 49-79; Schlueter, "The Kassel Miscellany of SeventeenthCentury Poems," 241-270

BALEs, PETer: Thadani, "For the Better Atteyning to Faire Writing': An Analysis of Two Competing WritingBooks, London, 1591," 422-466

BALLAds: Stoker, "John Marshall, John Evans, and the Cheap Repository Tracts, $1793-1800, " 81-118$
BIBLIOGRAPHICAL INDEXES, CATALOGUES, AND LisTs: Bromer and Struble, Aun Aprendo: A Comprehensive Bibliography of the Writings of Aldous Leonard Huxley, reviewed, 119-12; Geiger, "Collecting 'The Chief Glory of a Nation': A Look at the Marketplace for Printed American Verse," 319-324; Gray, "Walt Whitman's Marginalia as Occasional Practice," 467-494; Ives, Christina Rossetti: A Descriptive Bibliography, reviewed, 121-122; McEvilla, "A Catalogue of Book Advertisements from English Serials: Printed Drama, 1646-1668," 10-48; Resta, Belfagor: Indici 1946-2010, reviewed, 123-126; Stoddard and Whitesell, A Bibliographical Description of Books and Pamphlets of American Verse Printed from 1610 through 1820 , reviewed, 126-130

Bland, Mark B., "John Windet and the Transformation of the Book Trade, $1584-1610, " 151-192$

военме, јасов: Erben, “The Letters All Stand in One Root': Theory and Practice of Multilingualism in Early American Religious Poetry," 335-344

воOK TRADE: Bland, "John Windet and the Transformation of the Book Trade, 1584-1610," 151-192; McEvilla, "A Catalogue of Book Advertisements from English Serials: Printed Drama, 16461668," 10-48; McQuillen, "FifteenthCentury Book Networks: Scribes, Illuminators, Binders, and the Introduction of Print," 495-515; Stoker, "John Marshall, John Evans, and the Cheap Repository Tracts, $1793-1800$," $81-118$ 
вооквіNDing: McQuillen, "FifteenthCentury Book Networks: Scribes, Illuminators, Binders, and the Introduction of Print," 495-515

воокselling: McEvilla, "A Catalogue of Book Advertisements from English Serials: Printed Drama, 1646-1668," 10-48; McQuillen, "Fifteenth-Century Book Networks: Scribes, Illuminators, Binders, and the Introduction of Print," 495-515

вoston: Roberts, "Phillis Wheatley's Sarah Moorhead: An Initial Inquiry," 345-354

BRAINARD, JOHN: Gray, "Walt Whitman's Marginalia as Occasional Practice," 467-494

BroAdsides: McEvilla, "A Catalogue of Book Advertisements from English Serials: Printed Drama, 1646-1668," 10-48; Stoker, "John Marshall, John Evans, and the Cheap Repository Tracts, 1793-1800," 81-118

Bromer, David J., and Shannon Struble, Aun Aprendo: A Comprehensive Bibliography of the Writings of Aldous Leonard Huxley, reviewed, 119-121

савот, John: Shields, "John Rastell's The IIII Elements," 297-309

CALENDARs: McEvilla, "A Catalogue of Book Advertisements from English Serials: Printed Drama, 1646-1668," 10-48

catalogues: Arnar, The Book as Instrument: Stéphane Mallarmé, the Artist's Book and the Transformation of Print Culture, reviewed, 271-278; Orr, "The History, Uses, and Dangers of Halkett and Laing," 193-240

Cavitch, Max, "Clericus and the Lunatick," $367-376$

снАрвоокs: Stoker, “John Marshall, John Evans, and the Cheap Repository Tracts, 1793-1800," 81-118
Children's literature: Stoker, “John Marshall, John Evans, and the Cheap Repository Tracts, 1793-1800," 81-118

\section{CHRONOLOGICAL REFERENCES:}

15th century: McQuillen, "FifteenthCentury Book Networks: Scribes, Illuminators, Binders, and the Introduction of Print," 495-515; 16th century: Bland, "John Windet and the Transformation of the Book Trade, 1584-1610," 151-192; Johns, "The Uses of Print in the History of Science," (BSA Annual Address), 393-420; Thadani, "For the Better Atteyning to Faire Writing': An Analysis of Two Competing WritingBooks, London, 1591," 422-466; 17th century: Bland, "John Windet and the Transformation of the Book Trade, 1584-1610," 151-192; Erben, “The Letters All Stand in One Root': Theory and Practice of Multilingualism in Early American Religious Poetry," 335-344; Johns, "The Uses of Print in the History of Science," (BSA Annual Address), 393-420; McEvilla, "A Catalogue of Book Advertisements from English Serials: Printed Drama, ${ }_{1646}-$ 1668," 10-48; Orr, "The History, Uses, and Dangers of Halkett and Laing," 193-240; Schlueter, "The Kassel Miscellany of Seventeenth-Century Poems," 241-27o; Stoddard and Whitesell, A Bibliographical Description of Books and Pamphlets of American Verse Printed from 1610 through 1820 , reviewed, 126130; 18th century: Dussinger, "Mary Astell's Revisions of Some Reflections upon Marriage (1730)," 49-79; Geiger, "Collecting "The Chief Glory of a Nation': A Look at the Marketplace for Printed American Verse," 319-324; Orr, "The History, Uses, and Dangers of Halkett and Laing," 193-240; Stevens, "Of snatching captive souls from satan's paws': A Fundraising Poem for Wheelock's Charity School," 377-386; Stoddard and Whitesell, A Bibliographical Description of Books and Pamphlets of American Verse Printed from 1610 
through 1820, reviewed, 126-130; Stoker, "John Marshall, John Evans, and the Cheap Repository Tracts, 1793-1800," 81-118; 19th century: Cavitch, "Clericus and the Lunatick," 367-376; Geiger, "Collecting "The Chief Glory of a Nation': A Look at the Marketplace for Printed American Verse," 319-324; Gray, "Walt Whitman's Marginalia as Occasional Practice," 467-494; Ives, Christina Rossetti: A Descriptive Bibliography, reviewed, 121-122; Stoddard and Whitesell, A Bibliographical Description of Books and Pamphlets of American Verse Printed from 1610 through 1820, reviewed, 126-130; 20th century: Arnar, The Book as Instrument: Stéphane Mallarmé, the Artist's Book and the Transformation of Print Culture, reviewed, 271-278; Bromer and Struble, Aun Aprendo: A Comprehensive Bibliography of the Writings of Aldous Leonard Huxley, reviewed, 119-121; Kelly, Castleman, and Hoy, The Best of Both Worlds: Finely Printed Livres d'Artistes, 1910-2010, reviewed, 271-278; Resta, Belfagor: Indici 1946-2010, reviewed, 123-126

COlONial America: Stevens, “Of snatching captive souls from satan's paws': A Fundraising Poem for Wheelock's Charity School," 377-386; Stoddard and Whitesell, A Bibliographical Description of Books and Pamphlets of American Verse Printed from 1610 through 1820 , reviewed, 126-130; Erben, "The Letters All Stand in One Root': Theory and Practice of Multilingualism in Early American Religious Poetry," 335-344

COPYright: Stoker, "John Marshall, John Evans, and the Cheap Repository Tracts, 1793-1800," 81-118

COURT OF CHANCERY: Stoker, "John Marshall, John Evans, and the Cheap Repository Tracts, $1793^{-1800, " ~ 81-118 ~}$

DARTMOUTh COllege: Stevens, "Of snatching captive souls from satan's paws': A Fundraising Poem for Wheelock's Charity School," 377-386
DAting: McEvilla, "A Catalogue of Book Advertisements from English Serials: Printed Drama, 1646-1668," 10-48

DEAN, JOHN: Neuman, "The Versified Lives of Unknown Puritans," 355-366

DEvotional Literature: Cavitch, "Clericus and the Lunatick," 367-376; Erben, "The Letters All Stand in One Root': Theory and Practice of Multilingualism in Early American Religious Poetry," 335-344; Neuman, "The Versified Lives of Unknown Puritans," $355-366$

Dictionaries: Orr, "The History, Uses, and Dangers of Halkett and Laing," 193-240

DICTIONARY OF ANONYMOUS AND PSEUDONYMOUS ENGLISH LITERATURE: Orr, "The History, Uses, and Dangers of Halkett and Laing," 193-240

DRAKE, SIR FRANCIS: Shields, "John Rastell's The IIII Elements," 297-309

DRAMA: McEvilla, "A Catalogue of Book Advertisements from English Serials: Printed Drama, 1646-1668," 10-48; Orr, "The History, Uses, and Dangers of Halkett and Laing," 193-240

Dussinger, John A., "Mary Astell's Revisions of Some Reflections upon Marriage (1730)," 49-79

EARLY ENGLISH BOOKS ONLINE (EEBO): Orr, "The History, Uses, and Dangers of Halkett and Laing," 193-240

EIGHTEENTH CENTURY COLLECTIONS ONLINE (ECCO): Dussinger, "Mary Astell's Revisions of Some Reflections upon Marriage (1730)," 49-79

ENGLISH SHORT TITLE CATALOGUE (ESTC): Orr, "The History, Uses, and Dangers of Halkett and Laing," 193-240; Stoker, "John Marshall, John Evans, and the Cheap Repository Tracts, 1793-1800," $81-118$ 
Erben, Patrick M., “The Letters All Stand in One Root': Theory and Practice of Multilingualism in Early American Religious Poetry," 335-344

Erickson, Paul, "Poetry and Print in Early America," 293-295

Evans, John: Stoker, "John Marshall, John Evans, and the Cheap Repository Tracts, 1793-1800," 81-118

exhibitions: Kelly, Castleman, and Hoy, The Best of Both Worlds: Finely Printed Livres d'Artistes, 1910-2010, reviewed, $271-278$

Fraker, Robert, review of Stoddard and Whitesell, A Bibliographical Description of Books and Pamphlets of American Verse Printed from 1610 through 1820, 126-130; "'Stomach for them All': Collecting Minor American Verse in the TwentyFirst Century," 311-317

Geiger, Christina, "Collecting 'The Chief Glory of a Nation': A Look at the Marketplace for Printed American Verse," 319-324

Germany: McQuillen, "Fifteenth-Century Book Networks: Scribes, Illuminators, Binders, and the Introduction of Print," 495-515; Schlueter, "The Kassel Miscellany of Seventeenth-Century Poems," 241-270

GILbert, humphrey: Shields, "John Rastell's The IIII Elements," 297-309

GORDON, TRAVIS LYNN: "In Memoriam: Travis Lynn Gordon,” 288-291

Gray, Nicole, "Walt Whitman's Marginalia as Occasional Practice," 467-494

GREG, W. W.: McEvilla, "A Catalogue of Book Advertisements from English Serials: Printed Drama, 1646-1668," ${ }^{10-48}$

halkett, samuel: Orr, "The History, Uses, and Dangers of Halkett and Laing," $193-240$
HANDWRiting: Schlueter, "The Kassel Miscellany of Seventeenth-Century Poems," 241-270; Thadani, "For the Better Atteyning to Faire Writing': An Analysis of Two Competing Writing-Books, London, 1591," 422-466

HISTORY OF SCIENCE: Johns, "The Uses of Print in the History of Science," (BSA Annual Address), 393-420

Hoover, John Neal, "In Memoriam: Stuart B. Schimmel," $143^{-146}$

HUXLEY, ALDOUS LEONARD: Bromer and Struble, Aun Aprendo: A Comprehensive Bibliography of the Writings of Aldous Leonard Huxley, reviewed, 119-121

нумnвоокs: Phillips, "Versifying African Methodism: or, What Did Early African-American Hymnbooks Do?" $325-333$

ITALY: Resta, Belfagor: Indici 1946-2010, reviewed, 123-126

Ives, Maura, “Christina Rossetti: A Descriptive Bibliography, reviewed, 121-122

Jackson, Ian, review of Resta, Belfagor: Indici 1946-2010, 123-126

Johns, Adrian, "The Uses of Print in the History of Science," (BSA Annual Address), 393-420

Kelly, Jerry, Riva Castleman, and Anne H. Hoy, The Best of Both Worlds: Finely Printed Livres d'Artistes, 1910-2010, reviewed, $271-278$

LAING, JOHN: Orr, "The History, Uses, and Dangers of Halkett and Laing," 193-240

LIBRARIES: McQuillen, "Fifteenth-Century Book Networks: Scribes, Illuminators, Binders, and the Introduction of Print," 495-515; Schlueter, "The Kassel Miscellany of Seventeenth-Century Poems," 241-270 
London: Bland, "John Windet and the Transformation of the Book Trade, 1584-1610," 151-192; McEvilla, "A Catalogue of Book Advertisements from English Serials: Printed Drama, 16461668," 10-48; Stoker, "John Marshall, John Evans, and the Cheap Repository Tracts, $1793^{-1800, " ~ 81-118}$

LONGFELLOW, HENRY WADSWORTH: Shields, "John Rastell's The IIII Elements," 297-309

mallarmé, stéphane: Arnar, The Book as Instrument: Stéphane Mallarmé, the Artist's Book and the Transformation of Print Culture, reviewed, 271-278; Kelly, Castleman, and Hoy, The Best of Both Worlds: Finely Printed Livres d'Artistes, 1910-2010, reviewed, 271-278

MANUSCRIPTs: McQuillen, "FifteenthCentury Book Networks: Scribes, I1luminators, Binders, and the Introduction of Print," 495-515; Schlueter, "The Kassel Miscellany of SeventeenthCentury Poems," 241-270; Neuman, "The Versified Lives of Unknown $\mathrm{Pu}$ ritans," $355-366$

MARGINALIA: Gray, "Walt Whitman's Marginalia as Occasional Practice," 467-494; Johns, "The Uses of Print in the History of Science," (BSA Annual Address), 393-420

Marshall, john: Stoker, "John Marshall, John Evans, and the Cheap Repository Tracts, 1793-1800," 81-118

MCCORISON, MARCUS ALlen: "In Memoriam: Marcus Allen McCorison," 147-150

McEvilla, Joshua J., "A Catalogue of Book Advertisements from English Serials: Printed Drama, 1646-1668," 10-48

MCKenZie, D. F.: Johns, "The Uses of Print in the History of Science," (BSA Annual Address), 393-420

McQuillen, John T., "Fifteenth-Century Book Networks: Scribes, Illumina- tors, Binders, and the Introduction of Print," 495-515

Meyers, Jeffrey, review of Bromer and Struble, Aun Aprendo: A Comprehensive Bibliography of the Writings of Aldous Leonard Huxley, 119-121; review of Ives, Christina Rossetti: A Descriptive Bibliography, 121-122

Miscellanies: Schlueter, "The Kassel Miscellany of Seventeenth-Century Poems," 241-270

monasteries: McQuillen, "FifteenthCentury Book Networks: Scribes, I1luminators, Binders, and the Introduction of Print," 495-515

MOORHEAD, SARAH: Roberts, "Phillis Wheatley's Sarah Moorhead: An Initial Inquiry," 345-354

MORAL AND RELIGIOUS LITERATURE: Stoker, "John Marshall, John Evans, and the Cheap Repository Tracts, 17931800," 81-118

MORE, HANNAH: Stoker, "John Marshall, John Evans, and the Cheap Repository Tracts, 1793-1800," 81-118

Music: Geiger, "Collecting 'The Chief Glory of a Nation': A Look at the Marketplace for Printed American Verse," 319-324; Phillips, "Versifying African Methodism: or, What Did Early African-American Hymnbooks Do?" 325-333

NATIONAL ENDOWMENT FOR THE HUMANIties: Gray, "Walt Whitman's Marginalia as Occasional Practice," 467-494

NATIVE AMERICANS: Stevens, "'Of snatching captive souls from satan's paws': A Fundraising Poem for Wheelock's Charity School," 377-386

Neuman, Meredith Marie, "The Versified Lives of Unknown Puritans," 355-366

Newsвоoкs: Bland, "John Windet and the Transformation of the Book Trade, 
1584-1610," 151-192; McEvilla, "A Catalogue of Book Advertisements from English Serials: Printed Drama, ${ }_{1646}$ 1668," 10-48

NISBETT, RICHARD: Cavitch, "Clericus and the Lunatick," $367-376$

NOTES AND QUERIES (JOURNAL): Orr, “The History, Uses, and Dangers of Halkett and Laing," $193-240$

ornaments: Dussinger, "Mary Astell's Revisions of Some Reflections upon Marriage (1730)," 49-79

Orr, Leah, "The History, Uses, and Dangers of Halkett and Laing," 193-240

pamphlets: Dussinger, "Mary Astell's Revisions of Some Reflections upon Marriage (1730)," 49-79

PANKe, William: Thadani, "For the Better Atteyning to Faire Writing': An Analysis of Two Competing WritingBooks, London, 1591," 422-466

PARIS: Arnar, The Book as Instrument: Stéphane Mallarmé, the Artist's Book and the Transformation of Print Culture, reviewed, 271-278; Kelly, Castleman, and Hoy, The Best of Both Worlds: Finely Printed Livres d'Artistes, 1910-2010, reviewed, $271-278$

PERIODICALS: McEvilla, "A Catalogue of Book Advertisements from English Serials: Printed Drama, 1646-1668," 10-48; Resta, Belfagor: Indici 1946-2010, reviewed, $123-126$

Phillips, Christopher N., "Versifying African Methodism: or, What Did Early African-American Hymnbooks Do?" 325-333

PIRACY: Dussinger, "Mary Astell's Revisions of Some Reflections upon Marriage (1730)," 49-79

POETRY: Arnar, The Book as Instrument: Stéphane Mallarmé, the Artist's Book and the Transformation of Print Culture, reviewed, 271-278; Cavitch, "Clericus and the Lunatick," 367-376; Erben, "'The Letters All Stand in One Root': Theory and Practice of Multilingualism in Early American Religious Poetry," 335-344; Erickson, "Poetry and Print in Early America," 293-295; Fraker, "Stomach for them All': Collecting Minor American Verse in the Twenty-First Century," 311-317; Gray, "Walt Whitman's Marginalia as Occasional Practice," 467-494; Kelly, Castleman, and Hoy, The Best of Both Worlds: Finely Printed Livres d'Artistes, 1910-2010, reviewed, 271-278; Neuman, "The Versified Lives of Unknown $\mathrm{Pu}$ ritans," 355-366; Phillips, "Versifying African Methodism: or, What Did Early African-American Hymnbooks Do?" 325-333; Roberts, "Phillis Wheatley's Sarah Moorhead: An Initial Inquiry," 345-354; Schlueter, "The Kassel Miscellany of Seventeenth-Century Poems," 241-270; Stevens, "Of snatching captive souls from satan's paws': A Fundraising Poem for Wheelock's Charity School," 377-386

Ponsonby, William: Bland, "John Windet and the Transformation of the Book Trade, 1584-1610," 151-192

PRINTERS: Bland, "John Windet and the Transformation of the Book Trade, 1584-1610," 151-192; Dussinger, "Mary Astell's Revisions of Some Reflections upon Marriage (1730)," 49-79; Stoker, "John Marshall, John Evans, and the Cheap Repository Tracts, 1793-1800," $81-118$

PRINTING HistoRy: Bland, "John Windet and the Transformation of the Book Trade, 1584-1610," 151-192; Dussinger, "Mary Astell's Revisions of Some Reflections upon Marriage (1730)," 49-79; McEvilla, "A Catalogue of Book Advertisements from English Serials: Printed Drama, 1646-1668," 10-48; McQuillen, "Fifteenth-Century Book 
Networks: Scribes, Illuminators, Binders, and the Introduction of Print," 495-515; Orr, "The History, Uses, and Dangers of Halkett and Laing," 193240; Stoddard and Whitesell, A Bibliographical Description of Books and Pamphlets of American Verse Printed from 1610 through 1820, reviewed, 126-130

PRINTING PRACTICES: Arnar, The Book as Instrument: Stéphane Mallarmé, the Artist's Book and the Transformation of Print Culture, reviewed, 271-278; Bland, "John Windet and the Transformation of the Book Trade, 1584-1610," 151-192; Johns, "The Uses of Print in the History of Science," (BSA Annual Address), 393-420; McQuillen, "Fifteenth-Century Book Networks: Scribes, Illuminators, Binders, and the Introduction of Print," 495-515; Thadani, "For the Better Atteyning to Faire Writing': An Analysis of Two Competing WritingBooks, London, 1591," 422-466

PUblishing history: Cavitch, "Clericus and the Lunatick," 367-376; Dussinger, "Mary Astell's Revisions of Some Reflections upon Marriage (1730)," 49-79; Geiger, "Collecting 'The Chief Glory of a Nation': A Look at the Marketplace for Printed American Verse," 319-324; Johns, "The Uses of Print in the History of Science," (BSA Annual Address), 393-420; McQuillen, "Fifteenth-Century Book Networks: Scribes, Illuminators, Binders, and the Introduction of Print," 495-515; Orr, "The History, Uses, and Dangers of Halkett and Laing," 193-240; Phillips, "Versifying African Methodism: or, What Did Early African-American Hymnbooks Do?" 325-333; Stoker, "John Marshall, John Evans, and the Cheap Repository Tracts, 1793-1800," 81-118; Thadani, "For the Better Atteyning to Faire Writing': An Analysis of Two Competing Writing-Books, London, 1591," 422-466
RASTELl, John: Shields, “John Rastell's The IIII Elements," 297-309

READING PRACTICES: Gray, "Walt Whitman's Marginalia as Occasional Practice," 467-494; Johns, "The Uses of Print in the History of Science," (BSA Annual Address), 393-420; Phillips, "Versifying African Methodism: or, What Did Early African-American Hymnbooks Do?” 325-333

Resta, Antonio, Belfagor: Indici 1946-2010, reviewed, $123-126$

REVISIONS, EMENDATIONS, AND ADDITIONs: Dussinger, "Mary Astell's Revisions of Some Reflections upon Marriage (1730)," 49-79; Gray, "Walt Whitman's Marginalia as Occasional Practice," 467-494

Richardson, SAMuel: Dussinger, "Mary Astell's Revisions of Some Reflections upon Marriage (1730)," 49-79

Roberts, Wendy Raphael, "Phillis Wheatley's Sarah Moorhead: An Initial Inquiry," $345^{-3} 34$

rossetti, Christina: Ives, Christina Rossetti: A Descriptive Bibliography, reviewed, 121-122

SCHEYern ABbey: McQuillen, "Fifteenth-Century Book Networks: Scribes, Illuminators, Binders, and the Introduction of Print," 495-515

SCHIMMel, STUART в.: "In Memoriam: Stuart B. Schimmel," $143^{-146}$

Schlueter, June, "The Kassel Miscellany of Seventeenth-Century Poems," 241-270

SCRIBAL PRACTICES: McQuillen, "Fifteenth-Century Book Networks: Scribes, Illuminators, Binders, and the Introduction of Print," 495-515

Shields, David S., "John Rastell's The IIII Elements," 297-309 
SIDNEY, MARY: Schlueter, "The Kassel Miscellany of Seventeenth-Century Poems," 241-270

sterling, James: Shields, “John Rastell's The IIII Elements," 297-309

Stevens, Laura M., "Of snatching captive souls from satan's paws': A Fundraising Poem for Wheelock's Charity School," 377-386

Stoddard, Roger E., and David R. Whitesell; A Bibliographical Description of Books and Pamphlets of American Verse Printed from 1610 through 1820 , reviewed, 126-130; symposium, 293-295

Stoker, David, "John Marshall, John Evans, and the Cheap Repository Tracts, 1793-1800," 81-118

taylor, nathaniel: Cavitch, "Clericus and the Lunatick," $367-376$

Thadani, Simran, "'For the Better Atteyning to Faire Writing: An Analysis of Two Competing Writing-Books, London, 1591," 422-466

Thompson, Michael, review of Arnar, The Book as Instrument: Stéphane Mallarmé, the Artist's Book and the Transformation of Print Culture, 271-278; review of Kelly, Castleman, and Hoy, The Best of Both Worlds: Finely Printed Livres d'Artistes, 1910-2010, 271-278

TItLE PAges: McEvilla, "A Catalogue of Book Advertisements from English Serials: Printed Drama, 1646-1668," 10-48

TODD, WILLIAM BURTON: Winship, "In Memoriam: William Burton Todd," 7-9

TYPOgRAPHY: Arnar, The Book as Instrument: Stéphane Mallarmé, the Artist's Book and the Transformation of Print Culture, reviewed, 271-278; Bland, "John Windet and the Transformation of the Book Trade, 1584-1610," 151-192
UNIVERSITY OF TEXAS AT AUSTIN: Gray, "Walt Whitman's Marginalia as Occasional Practice," 467-494

wheatley, phillis: Geiger, "Collecting 'The Chief Glory of a Nation': A Look at the Marketplace for Printed American Verse," 319-324; Roberts, "Phillis Wheatley's Sarah Moorhead: An Initial Inquiry," 345-354

WHEELock, ElEAZAR: Stevens, “Of snatching captive souls from satan's paws': A Fundraising Poem for Wheelock's Charity School," 377-386

whitman, walt: Gray, "Walt Whitman's Marginalia as Occasional Practice," 467-494

Winship, Michael, "In Memoriam: William Burton Todd," 7-9; "In Memoriam: Marcus Allen McCorison," 147-150

wolfe, John: Bland, "John Windet and the Transformation of the Book Trade, 1584-1610," 151-192

woodcuts: Stoker, "John Marshall, John Evans, and the Cheap Repository Tracts, 1793-1800," 81-118

Compiled by John V. NAnce 


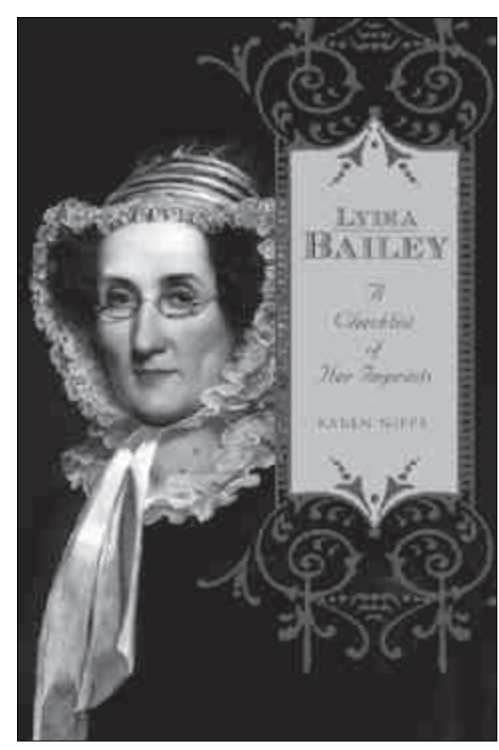

“Karen Nipps's useful checklist of

Lydia Bailey's imprints and her perceptive account of Bailey's

business methods provide a valuable glimpse into the inner workings of the Philadelphia book trade at the peak of its prosperity."

—John Bidwell, The Morgan Library and Museum

\section{Lydia Bailey}

A Checklist of Her Imprints

Karen Nipps

"In this study, Karen Nipps draws together a remarkable amount of information about the life and work of Lydia R. Bailey, a job and contract printer in Philadelphia during the early years of the United States. The picture of Bailey's career that emerges goes a long way toward enriching our understanding of the early American book trades in all their variety."

—Michael Winship, University of Texas at Austin Lydia Bailey was a leading printer in Philadelphia for decades. During her career, she operated a shop that at its height had more than forty employees, acted as city printer for over thirty years, and produced almost a thousand imprints bearing her name. Not surprisingly, sources reveal that she was closely associated with many of her now better-known contemporaries both in the book trade and beyond, people like her father-in-law, Francis Bailey; Mathew Carey; Philip Freneau; and Harriet Livermore. Through a detailed examination and analysis of various sources, Karen Nipps portrays Bailey's experience within the context of her social, political, religious, and book environments.

328 pages $\mid 1$ color/10 b\&w illustrations $\mid$ \$79.95 cloth Penn State Series in the History of the Book Published by The Pennsylvania State University Press for the Bibliographical Society of America in association with the Houghton Library, Harvard University, and the Library Company of Philadelphia.

\section{penn state press}

820 N. University Drive, USB 1, Suite C | University Park, PA 16802 | info@psupress.org WWW.PSUPRESS.ORG | BSA MEMBERS RECEIVE A 20\% DISCOUNT, USE CODE BSA. 


\section{Membership in \\ The Bibliographical Society of America}

is open to all those interested in bibliographical problems and projects.

Libraries are welcome as institutional members. Members receive four issues of the Papers and discounts on the Society's publications.

Dues for annual (January to December) membership are $\$ 65$ for individuals, $\$ 100$ for institutions, and $\$ 100$ for contributing members. Student membership is $\$ 20$ for graduate students and undergraduates, with proof of eligibility. Sustaining membership is $\$ 250$, and individual life membership is $\$ 1,250$.

Members residing outside the U.S. should add a \$15 surcharge for postage.

See www.bibsocamer.org for an application form and information about the

Society or mail inquiries to the Executive Secretary, P. O. Box 1537

Lenox Hill Station, New York, NY 10021

The Bibliographical Society of America is a $501(c)(3)$ charitable organization. All contributions to the Society are tax deductible to the extent provided by law. 